\title{
A INFRA-ESTRUTURA ESCOLAR E AS CARACTERÍSTICAS FAMILIARES INFLUENCIANDO A FREQUÊNCIA E O ATRASO NO ENSINO FUNDAMENTAL
}

\author{
Rosangela Maria Pontili
}

\begin{abstract}
Dissertação apresentada à Escola Superior de Agricultura "Luiz de Queiroz", Universidade de São Paulo, para obtenção do Título de Mestre em Ciências, Área de Concentração: Economia Aplicada.
\end{abstract}

\author{
P I R A C I C A B A \\ Estado de São Paulo - Brasil
}

Novembro - 2004 


\title{
A INFRA-ESTRUTURA ESCOLAR E AS CARACTERÍSTICAS FAMILIARES INFLUENCIANDO A FREQUÊNCIA E O ATRASO NO ENSINO FUNDAMENTAL
}

\author{
Rosangela Maria Pontili \\ Bacharel em Ciências Econômicas
}

Orientador: Profa. Dra. ANA LÚCIA KASSOUF

\begin{abstract}
Dissertação apresentada à Escola Superior de Agricultura "Luiz de Queiroz", Universidade de São Paulo, para obtenção do Título de Mestre em Ciências, Área de Concentração: Economia Aplicada.
\end{abstract}

\author{
P I R A C I C A B A \\ Estado de São Paulo - Brasil
}

Novembro - 2004 


\section{Dados Internacionais de Catalogação na Publicação (CIP) DIVISÃO DE BIBLIOTECA E DOCUMENTAÇÃO - ESALQ/USP}

Pontili, Rosangela Maria

A infra-estrutura escolar e as características familiares influenciando a freqüência e o atraso no ensino fundamental / Rosangela Maria Pontili. - - Piracicaba, 2004.

$131 \mathrm{p}$.

Dissertação (Mestrado) - - Escola Superior de Agricultura Luiz de Queiroz, 2004. Bibliografia.

1. Análise de regressão 2. Censo demográfico 3. Comunidade urbana 4. Ensino fundamental 5. Escola Pública - Qualidade 6. Família - Condições sócio-econômicas 7. Pesquisa educacional 8. Política pública 9. Qualidade de vida I. Título

CDD 372

\section{"Permitida a cópia total ou parcial deste documento, desde que citada a fonte - $\mathrm{O}$ autor"}




\section{DEDICO}

Ao meu amigo e futuro esposo - Tato

\section{OFEREÇO}

Com todo carinho, a meus pais Antonio e Gracilina. 


\section{AGRADECIMENTOS}

Durante o mestrado, muitas dificuldades são enfrentadas ao longo do caminho. Se não fosse a presença de algumas pessoas especiais, mais tortuosos seriam esses caminhos e, talvez, não seria possível completar a jornada. Essas pessoas merecem um agradecimento especial.

A meu grande amor, Deoclécio José Barilli - Tato -por todas as vezes que aceitou dividir comigo, os problemas e vitórias pelos quais passei. Também agradeço aos pais do Tato, dona Judith e seu Deonísio, bem como a seus irmãos, por aceitarem que eu faça parte dessa maravilhosa família.

A minha família: meu pai Antonio Pontili Filho; minha mãe Gracilina Corrêa Pontili; meus irmãos Donizete, Angela e Eloisa; meus cunhados Débora, Sérgio e Levi; meus sobrinhos Daniel, Greice, Daiane, Larissa e Isabelly. Muito obrigada por fazerem parte de minha vida e por terem confiado que eu alcançaria a vitória.

Aos amigos da PJ, valeu a troca de experiência e o carinho de vocês.

Em Piracicaba ganhei uma segunda família. Agradeço ao Serviço Social do Campus “Luiz de Queiroz” (DVATCOM) pela oportunidade de morar na Vila Estudantil. Na casa 01, nós pudemos rir, brincar, chorar...Agradeço o carinho do Penha, Simpson, Minuto, Junio, Henrique, Juan, Analy e Miriam. Agradeço a amizade do Anderson, Júlio e Elio. De modo especial, agradeço a vocês minhas irmãzinhas Ana Paula, Raquel e Kátia. Valeu pela convivência...eu jamais lhes esquecerei!

Valeu Julcemar (Xaxim), Paulo Nazareno e tantos outros colegas de turmas anteriores, com os quais pude contar nos momentos de dúvidas. Muito obrigada Margarida, Rosycler, Lana, Piedade e Lucílio, pelas palavras de carinho, pelas orações e por me ajudarem, sempre que precisei. 
Agradeço aos colegas de projeto, Conchas e Marcio, pela convivência ao longo do último ano. Especialmente à Andréa Ferro, que tantas vezes me ajudou, mostrando-se prestativa e amiga, meus sinceros agradecimentos.

Aos amigos e confidentes Jonas, Moisés e Ingridt. Com um carinho todo especial às amigas Janete e Madalena. Vocês foram muito importantes nesses dois últimos anos.

A minha querida orientadora - Ana Lúcia Kassouf. Você foi mais que orientadora, foi amiga e irmã e eu tenho muito que lhe agradecer nesse final de jornada.

Ao Departamento de Economia da Esalq, pela infra-estrutura, que nos possibilita a realização das atividades do mestrado. Pelo trabalho da Maielli, dona Maria e outros funcionários, sempre tão dedicados e prestativos.

Aos funcionários do Ministério da Educação (MEC), dentre eles Jorge Rondelli e Jader Leite, pelas informações prontamente prestadas, no decorrer desse trabalho. Também aos funcionários da Secretaria Estadual da Educação de Pernambuco, dentre eles, a Sra. Lucia Rego.

Como não poderia deixar de ser, fica aqui um agradecimento mais que especial à DEUS, pelo dom da vida, sem o qual todo resto não seria possível. 


\section{SUMÁRIO}

Página

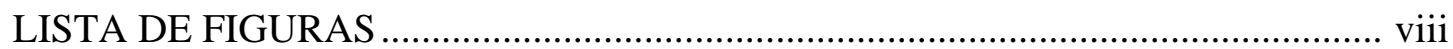

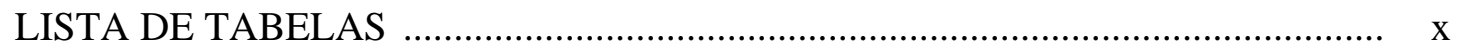

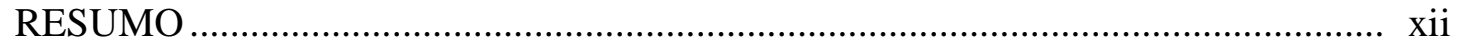

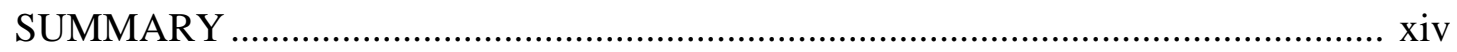

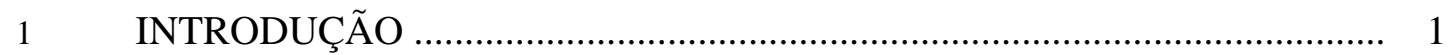

1.1 Definição do problema e justificativa do estudo ............................................. 4

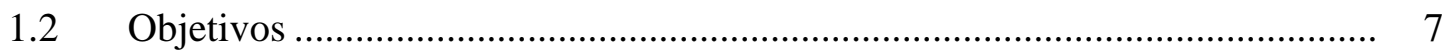

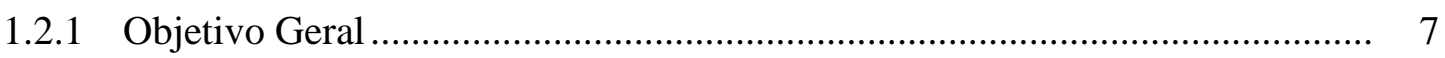

1.2.2 Objetivos específicos............................................................................... 7

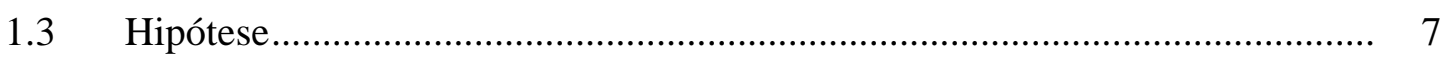

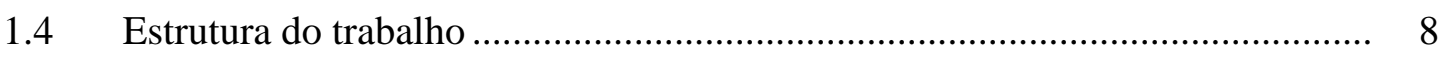

2 FATORES RELACIONADOS A DIFERENÇAS REGIONAIS E POLÍTICAS EDUCACIONAIS .............................................................. 9

2.1 Abordagens recentes das diferenças regionais do Brasil ................................ 10

2.1.1 Análise comparativa dos estados de Pernambuco e São Paulo ........................ 14

2.2 Mudanças recentes dos investimentos em educação no Brasil ....................... 21

2.2.1 A preocupação com a defasagem escolar......................................................... 29

3 REVISÃO DE LITERATURA ….......................................................... 38

$3.1 \quad$ A teoria do Capital Humano......................................................................... 38

3.2 Aproximações empíricas do modelo Becker-Tomes ...................................... 40

3.3 Pesquisas que reuniram variáveis da infra-estrutura escolar e das características familiares 
4 MODELO ECONOMÉTRICO, MATERIAL E MÉTODOS........................ 49

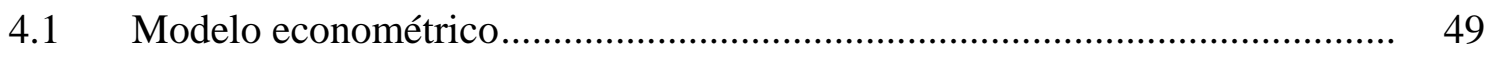

4.1.1 Efeitos Marginais ........................................................................ 51

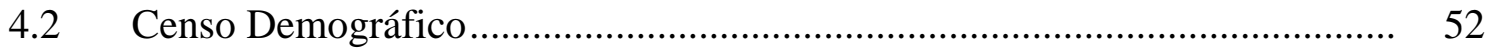

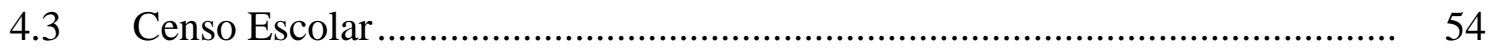

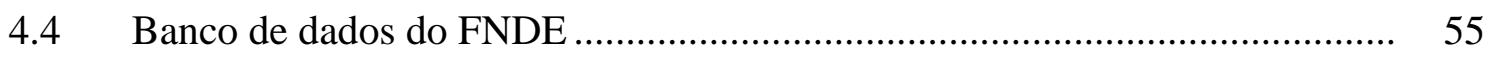

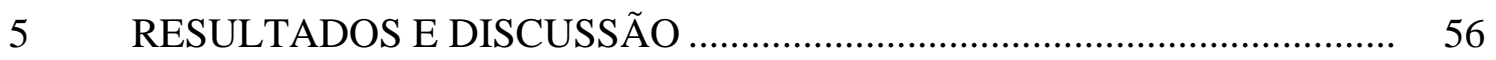

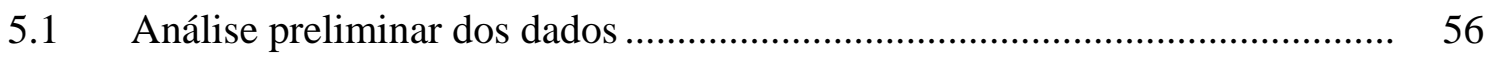

5.2 Análise econométrica da freqüência e do atraso escolar............................. 77

5.2.1 Resultados para a freqüência escolar .................................................... 81

5.2.2 Resultados para o atraso escolar........................................................ 91

5.3 Simulações para orientar a seleção de políticas públicas ............................. 103

5.3.1 Simulações associadas à probabilidade de freqüência escolar..................... 104

5.3.2 Simulações associadas à probabilidade de atraso escolar ........................... 109

5.4 Análise de situações extremas............................................................... 114

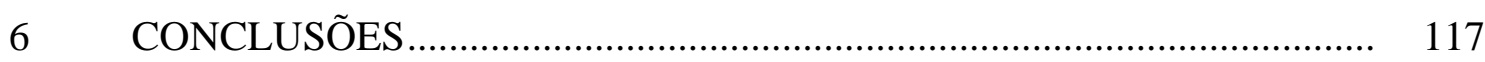

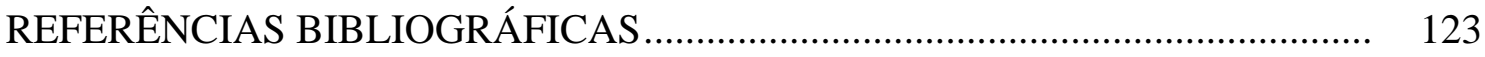




\section{LISTA DE FIGURAS}

Página

1 Freqüência de crianças na escola e freqüência de crianças com atraso escolar, estratificada segundo a idade - São Paulo e Pernambuco - 2000...................... 59

2 Freqüência de crianças na escola e freqüência de crianças com atraso escolar, segundo o sexo e a situação do domicílio - São Paulo e Pernambuco - 2000.....

3 Freqüência de crianças na escola e freqüência de crianças com atraso escolar, segundo a renda familiar per capita - São Paulo e Pernambuco - 2000.

4 Freqüência de crianças na escola e freqüência de crianças com atraso escolar, segundo a cor ou raça declarada na pesquisa - São Paulo e Pernambuco 2000 .

5 Freqüência de crianças na escola e freqüência de crianças com atraso escolar, segundo as mesorregiões - São Paulo - 2000.

6 Freqüência de crianças na escola e freqüência de crianças com atraso escolar, segundo as mesorregiões - Pernambuco - 2000.

7 Efeito da interação entre a escolaridade do chefe de família e a média de anos de estudo do professor sobre a freqüência escolar de São Paulo.

8 Efeito das interações entre o logaritmo da renda familiar per capita e a escolaridade do chefe de família, com o logaritmo da média salarial do professor, sobre a freqüência escolar de Pernambuco.

9 Efeito das interações entre o logaritmo da renda familiar per capita e a escolaridade do chefe de família, com a proporção de escolas com laboratório de informática, sobre o atraso escolar de São Paulo. 
10 Efeito da interação entre o logaritmo da renda familiar per capita e a escolaridade do chefe de família, com a proporção de escolas com laboratório de informática, sobre o atraso escolar de Pernambuco

11 Alterações na probabilidade de freqüência à escola da criança paulista, após mudanças em quatro variáveis explicativas.

12 Alterações na probabilidade de freqüência à escola da criança pernambucana, após mudanças em quatro variáveis explicativas.

13 Alterações na probabilidade de atraso escolar da criança paulista, após mudanças em quatro variáveis explicativas.

14 Alterações na probabilidade de atraso escolar da criança pernambucana, após mudanças em quatro variáveis explicativas.

15 Probabilidade de freqüência e atraso escolar, segundo condições socioeconômicas extremas. 


\section{LISTA DE TABELAS}

Página

1 Indicadores socioeconômicos para os estados do Nordeste.............................. 15

2 Indicadores socioeconômicos para os estados do Sudeste................................. 17

3 Indicadores de desempenho educacional nos estados de Pernambuco e São Paulo.

4 Média de desempenho no exame SAEB, na $4^{\mathrm{a}}$ e $8^{\mathrm{a}}$ séries do ensino fundamental, para o ano 2001 - disciplinas de português e matemática.

5 Índice de Desenvolvimento Humano e Indicadores educacionais - Brasil e países da América Latina - 2002 ................................................................ 22

6 FUNDEF: valor mínimo nacional por aluno/ano - 1997 - 2002. ...................... 25

7 Número de alunos atendidos pelos programas PNAE e PDDE - Brasil - 1995 a 2002 .

8 Número total de escolas e quantidade de escolas que apresentaram melhorias na infra-estrutura - Brasil - 1999 a 2003

9 Taxas de rendimento escolar, distorção idade-série e distorção idadeconclusão do ensino fundamental - Brasil - 1999 a 2003.

10 Evolução da distorção idade-série no ensino fundamental dos estados de Pernambuco e São Paulo - 1999 a 2003.

11 Freqüência de crianças na escola e freqüência de crianças com atraso escolar, segundo a situação do domicílio e o sexo do chefe de família - São Paulo e Pernambuco - 2000

12 Freqüência de crianças na escola e freqüência de crianças com atraso escolar, segundo a situação do domicílio e a escolaridade do chefe de família - São Paulo e Pernambuco - 2000 
13 Freqüência de crianças na escola e freqüência de crianças com atraso escolar, segundo a situação do domicílio e a média de anos de estudo do professor São Paulo e Pernambuco - 2000.

14 Freqüência de crianças na escola e freqüência de crianças com atraso escolar, segundo a situação do domicílio e a média salarial do professor - São Paulo e Pernambuco - 2000.

15 Freqüência de crianças na escola e freqüência de crianças com atraso escolar, segundo a situação do domicílio e a proporção de escolas com laboratório de informática - São Paulo e Pernambuco - 2000.

16 Freqüência de crianças na escola e freqüência de crianças com atraso escolar, segundo a situação do domicílio e a proporção de escolas com biblioteca São Paulo e Pernambuco - 2000.

17 Freqüência de crianças na escola e freqüência de crianças com atraso escolar, segundo a situação do domicílio e a média de alunos por turma - São Paulo e Pernambuco - 2000.

18 Média e desvio padrão das variáveis a serem utilizadas nas regressões da freqüência e atraso escolar - São Paulo.

19 Média e desvio padrão das variáveis a serem utilizadas nas regressões da freqüência e atraso escolar - Pernambuco.

20 Efeitos marginais das regressões próbite para a freqüência à escola no ensino fundamental de escolas públicas, localizadas em área urbana, de São Paulo......

21 Efeitos marginais das regressões próbite para a freqüência à escola no ensino fundamental de escolas públicas, localizadas em área urbana, de Pernambuco..

22 Efeitos marginais das regressões próbite para o atraso escolar no ensino fundamental, de escolas públicas, localizadas em área urbana, de São Paulo.....

23 Efeitos marginais das regressões próbite para o atraso escolar no ensino fundamental, de escolas públicas, localizadas em área urbana, de Pernambuco.

24 Resultados das interações entre as características familiares e a infra-estrutura escolar, sobre a freqüência e o atraso escolar - São Paulo e Pernambuco. 


\title{
A INFRA-ESTRUTURA ESCOLAR E AS CARACTERÍSTICAS FAMILIARES INFLUENCIANDO A FREQUENCIA E O ATRASO NO ENSINO FUNDAMENTAL
}

\author{
Autor: ROSANGELA MARIA PONTILI \\ Orientador: Profa. Dra. ANA LUCIA KASSOUF
}

\section{RESUMO}

Diversos estudos realizados na área econômica têm mostrado a importância da escolaridade para a melhoria da qualidade de vida das pessoas. Apesar disso, o nível médio de escolaridade no Brasil é de 6,4 anos na população adulta, considerado baixo, se comparado a outros países da América Latina. Em vista disso, na década de 1990, foram instituídas diversas mudanças na forma de gestão do ensino público brasileiro, com objetivo de melhorar sua qualidade e motivar o interesse da criança pela escola. $\mathrm{O}$ presente trabalho inseriu-se nessa discussão ao propor uma avaliação da influência que a infra-estrutura escolar e as características familiares exercem sobre a freqüência e o atraso no ensino fundamental. Dadas as diferenças regionais existentes no Brasil, fez-se uma comparação entre os estados de São Paulo e Pernambuco. Para tanto, foram feitas análises de regressões, utilizando-se do modelo próbite, e as bases de dados foram o censo demográfico, o censo escolar e as transferências do Fundo Nacional de Desenvolvimento da Escola (FNDE), do ano 2000. Tais análises concentraram-se nas escolas públicas, da área urbana, dos dois estados. Além disso, foram realizadas interações entre variáveis das características familiares e variáveis da infra-estrutura escolar, a fim de verificar as formas mais eficientes de se colocar e manter a criança na 
escola, garantindo-lhe o avanço nos estudos. Questionou-se, portanto, se é mais interessante para o governo investir na melhoria da qualidade das escolas, ou em iniciativas que melhoram as condições socioeconômicas da família. Foram, também, realizadas simulações para avaliar os impactos de uma melhoria na qualidade das escolas, versus uma melhoria das condições socioeconômicas das famílias, na freqüência e no atraso escolar do estudante. Os resultados mostraram que políticas públicas voltadas para um aumento do salário, ou da escolaridade do professores, assim como para uma melhoria dos equipamentos disponíveis na escola, beneficiarão mais as crianças pertencentes a famílias com chefes pouco escolarizados e/ou com uma baixa renda familiar per capita. Além disso, percebeu-se que em Pernambuco, a política pública de maior impacto sobre a freqüência escolar foi o aumento do salário do professor e sobre o atraso escolar foi o aumento da escolaridade do chefe de família. Para São Paulo, a melhor opção seria aumentar a renda familiar per capita, tanto no caso da freqüência, quanto no caso do atraso escolar. Conclui-se, então, que a adoção de políticas públicas deve levar em consideração o lugar onde as mesmas serão adotadas, bem como os objetivos a serem atingidos na área da educação. Acredita-se, no entanto, que políticas voltadas para melhorar as características familiares geram resultados somente no longoprazo. Por isso, sugere-se que no curto-prazo sejam priorizadas as políticas capazes de melhorar a qualidade das escolas públicas que oferecem o ensino fundamental, na área urbana, dos dois estados. Sugere-se, também, que os investimentos públicos na área da educação priorizem Pernambuco, em função das diferenças socioeconômicas existentes entre os dois estados. 


\title{
SCHOOL INFRASTRUCTURE AND FAMILY CHARACTERISTICS AFFECTING FREQUENCY AND DELAY IN PRIMARY AND SECONDARY SCHOOL
}

\author{
Author: ROSANGELA MARIA PONTILI
}

Adviser: Profa. Dra. ANA LUCIA KASSOUF

\section{SUMMARY}

Many studies in the economic field have showed the importance of education to increase the wellbeing of the society. However, the adult population in Brazil has, on average, 6.4 years of education, which is considered low when compared to other Latin American countries. Trying to improve the educational indicators, in the 90's, many changes were implemented in the Brazilian public school system. The objective of the present study is to evaluate school infrastructure and family characteristics affecting children's decision to study or to drop out from school (frequency and school delay in primary and secondary levels). The analyses were concentrated in public schools located in the urban areas of Pernambuco and São Paulo states. Demographic census, school census and government spending data from 2000 were used to run a Probit model, whether a child was in school or not and whether a child was in lower grade for his age or not. Interactions between family's characteristics and school infrastructure, as well as some simulations, were done to verify what would be the best possible resource allocation to improve children's education. The results showed that public policies that increased teacher's schooling or teacher's salaries, and policies that improved the school's equipments would benefit more children from low 
income families and/or with low educated parents. Moreover, in Pernambuco, the teacher's salary caused the greater impact in the children's frequency to school, while the teacher's schooling had the larger impact in the children's school delay. On the other hand, in São Paulo, the best option would be to increase per capita family income, either to increase frequency or decrease delay in school. It is known that policies to improve families' characteristics will produce results more in the long run. Therefore, policies that would improve the schools' infrastructure and consequently the quality of the schools are suggested in the short run. Moreover, the investment should focus Pernambuco due to the lower socio-economic indicators compared to São Paulo. 


\section{INTRODUÇÃO}

"Porque esta é a mensagem que ouvistes desde o princípio: que nos amemos uns aos outros.”

(I João 3:11)

Há décadas, a literatura nacional e internacional tem se preocupado em mostrar a importância da escolaridade para a melhoria da qualidade de vida das pessoas. Em um estudo realizado para países em desenvolvimento, Behrman \& Wolfe (1984) concluíram que investimentos em educação provocam um impacto socio-econômico positivo na geração de renda da economia.

Trabalhos utilizando dados do Brasil mostram que o acréscimo de um ano na escolaridade eleva a renda dos indivíduos em até 16\% (Kassouf, 1997; Kassouf, 2001; Ueda \& Hoffmann, 2002; Barros \& Ramos, 1992). Outro estudo mostra que se a escolaridade das mães analfabetas passasse para o nível primário ou ginasial, a desnutrição de crianças na pré-escola reduzir-se-ia de 25\% para 15\% (Kassouf \& Senauer, 1996). Estudos da Organização Internacional do Trabalho (OIT) têm apontado para o fato de pessoas mais educadas serem mais cientes dos seus direitos e criarem filhos mais educados e mais saudáveis, diminuindo o trabalho infantil no longo prazo.

Segundo a Pesquisa Nacional por Amostra de Domicílios (PNAD, 2001), o nível médio de escolaridade no Brasil é de 6,4 anos na população adulta. Nível, esse, considerado baixo se comparado a outros países da América Latina, com semelhante grau de desenvolvimento econômico (Vasconcellos, 2003). De acordo com Castro \& Menezes (2003), a partir do início da década de 1990 as discussões ocorridas em torno 
dos benefícios da escolaridade, bem como da má qualidade do ensino ministrado no Brasil, provocaram mudanças nas normas institucionais, bem como no financiamento público da educação. Tais mudanças atingiram, especialmente, crianças estudantes da $1^{a}$ à $8^{\mathrm{a}}$ série do ensino fundamental.

Elevar a freqüência escolar e manter a criança na escola é o primeiro passo para elevar o nível médio de escolaridade de um país. Em função disso, é crescente o número de estudos, tais como Case \& Deaton (1999) e Binder (1999), que avaliam o impacto da renda familiar, da escolaridade dos pais e do local de residência na probabilidade de a criança ingressar e/ou permanecer na escola. Por outro lado, alguns trabalhos têm se preocupado em acrescentar variáveis ligadas à quantidade e qualidade da oferta escolar, a fim de verificar sua influência na obtenção da educação infantil e nas taxas de retorno à escolaridade. Summers \& Wolfe (1977), por exemplo, demonstraram que investimentos em infra-estrutura escolar influenciavam no resultado final de estudantes negros e estudantes de baixa renda. Além desses, Card \& Krueger (1992) comprovaram que reduções na razão professor/aluno e/ou aumentos nos salários dos professores aumentavam a taxa de retorno salarial de estudantes norte-americanos.

No Brasil, no entanto, a despeito das diversas mudanças políticoeducacionais ocorridas na última década, poucos estudos têm sido direcionados para entender os fatores determinantes da freqüência e do atraso escolar infantil. Recentemente, Barros et al. (2001) mostraram que o número de séries completadas por um indivíduo é fortemente influenciado pela educação dos pais e/ou pela renda domiciliar per capita. Sua amostra abrangeu pessoas com idade entre 11 e 25 anos, que poderiam estar cursando da $5^{\text {a a }} 8^{\text {a }}$ série do ensino fundamental, ou o ensino médio. Vasconcellos (2003), fez uma análise da freqüência e do atraso escolar no ensino fundamental brasileiro, no período de 1981 a 1999, dando maior ênfase ao estudo de uma possível relação causal entre renda familiar e indicadores educacionais.

Diante do acima exposto, no presente trabalho, foi feita uma comparação dos impactos que, tanto as características individuais e familiares, quanto as características 
associadas à infra-estrutura escolar e à melhor qualidade do ensino, exercem sobre o aumento da freqüência à escola e sobre a redução do atraso escolar, no ensino fundamental, de escolas públicas, localizadas em área urbana. Para tanto, escolheram-se dois estados bastante distintos do ponto de vista socioeconômico, avaliando-se possíveis diferenças quanto ao desempenho de políticas governamentais capazes de elevar a freqüência escolar e/ou reduzir a defasagem idade-série entre os estudantes. Assim sendo, foram analisados os estados de São Paulo e Pernambuco, utilizando-se modelos próbite, cuja variável dependente reflete a freqüência ou não da criança na escola, além da ocorrência ou não de atraso escolar.

A qualidade das escolas foi medida pelo número de alunos por classe, nível de escolaridade e remuneração do professor, gastos públicos com alimentação escolar e transferência de dinheiro direto para a escola, além da proporção de escolas, no município, com laboratório de informática e bibliotecas. Os fatores que representam as características individuais e familiares englobaram a renda familiar per capita, a escolaridade, sexo e idade do chefe da família, assim como a idade, sexo e cor ou raça da criança.

Na obtenção das variáveis selecionadas, o Censo Demográfico de 2000 constituiu-se em uma rica base de dados, a partir da qual foi possível selecionar informações ligadas às características pessoais e familiares da criança utilizando-se os microdados. Essas variáveis foram cruzadas com os bancos de dados divulgados pelo Ministério da Educação, tais como o Censo Escolar e os repasses do FNDE, nos quais encontram-se informações sobre a infra-estrutura das escolas em cada município.

Foram estimadas, também, interações entre a escolaridade da pessoa responsável pela família e a renda familiar per capita, com variáveis representativas da infra-estrutura escolar, pensando na melhor alocação dos recursos destinados aos mais necessitados. Nesse caso, um efeito complementar entre a renda e a infra-estrutura escolar indica que investir na melhoria das escolas beneficia os ricos, mais do que os pobres. Da mesma forma, a existência de um efeito substituição entre a infra-estrutura 
das escolas e a escolaridade do chefe da família revela que crianças pertencentes a famílias com chefes menos escolarizados estariam sendo mais beneficiadas por melhorias na qualidade da escola. Ademais, foram realizadas simulações comparando variáveis da infra-estrutura escolar, com as características familiares da criança, a fim de avaliar que tipo de intervenção teria maior impacto nas duas variáveis dependentes selecionadas.

A partir dos resultados encontrados foram sugeridas políticas públicas, com o intuito de auxiliar a tomada de decisão de dirigentes governamentais na implantação de programas sociais na área da educação.

\subsection{Definição do problema e justificativa do estudo}

A Lei de Diretrizes e Bases da Educação Nacional entende que "a educação abrange os processos formativos que se desenvolvem na vida familiar, na convivência humana, no trabalho, nas instituições de ensino e pesquisa, nos movimentos sociais e organizações da sociedade civil e nas manifestações culturais" (LDB, Art. 1º, 1996).

Nesse processo de formação pessoal, a educação escolar é obtida em instituições de ensino, sendo composta por educação básica e educação superior. A educação básica é dividida em três níveis, sendo eles a educação infantil (também conhecida como pré-escola), o ensino fundamental (que compreende da $1^{\mathrm{a}}$ a $8^{\mathrm{a}}$ série) e o ensino médio. Em 2001, de acordo com o Ministério da Educação e Desporto (MEC), o ensino fundamental matriculou um total de 35,3 milhões de alunos em todo Brasil, sendo que 26,82 milhões dessas matrículas correspondiam às crianças entre 7 e 14 anos. Além disso, os dados da Pesquisa Nacional por Amostra de Domicílios (PNAD) (2001) mostram que 96,46\% das crianças nessa faixa etária estavam na escola.

Os números acima, porém, variam de acordo com a realidade socioeconômica dos estados e regiões. Comparando-se os dados da PNAD para os anos 
de 1999 e 2001, percebe-se que no estado de São Paulo o percentual de crianças entre 7 e 14 anos que estavam estudando, na zona rural, aumentou de 93,57\% para 97,39\%, enquanto que, na zona urbana 95,73\% dessas crianças estavam estudando em 1999, aumentando para 98,02\% em 2001. O estado de Pernambuco também teve um crescimento no número de crianças com idade entre 7 e 14 anos que estavam estudando. Na zona rural esse percentual era de 87,59\% em 1999, passando para 93,66\% em 2001. Quanto ao resultado obtido para a zona urbana, houve um aumento de 90,21\% em 1999, para 94,31\% em 2001.

Outra fonte de constantes discussões no poder público tem sido o indicador de atraso escolar. Segundo a PNAD de 1999, 62\% dos estudantes que estavam no ensino fundamental, com idade inferior a 25 anos, moradores da área rural de Pernambuco, tinham idade superior à adequada para a série que estavam cursando. Na área urbana, esse percentual era de $45 \%$ dos estudantes. Para São Paulo, os dados mostram que 27\% das crianças da zona rural e $20 \%$ dos estudantes da zona urbana estavam atrasados em seus estudos. Em 2001, apesar de ter havido uma melhora na defasagem escolar, as informações da PNAD evidenciam que os percentuais ainda eram relativamente altos. Em Pernambuco, a porcentagem de alunos atrasados caiu para 56\% na zona rural e 41\% na zona urbana. Em São Paulo, tais percentuais eram de 24\% dos residentes na área rural e 15\% dos moradores na área urbana.

Os dados do Censo Escolar de 1999 mostram que o número de alunos por docente, nas turmas de $1^{\mathrm{a}}$ a $4^{\mathrm{a}}$ série, era 31 no estado de São Paulo e 30 em Pernambuco. As turmas de $5^{\mathrm{a}}$ a $8^{\mathrm{a}}$, por sua vez, apresentavam uma quantidade de 26 alunos por docente em São Paulo e 28 em Pernambuco.

Apesar das informações referentes ao número de alunos por docente serem bastante parecidas em São Paulo e Pernambuco, os dados da PNAD mostram que o salário mensal dos professores, para o ano de 1999, foi bastante distinto nos dois estados. Em Pernambuco, a remuneração dos professores que lecionavam de $1^{\mathrm{a}}$ a $4^{\mathrm{a}}$ série era de R\$ 185,21 na zona rural e de R\$ 237,05 na zona urbana. Os salários para os 
professores de $5^{\mathrm{a}}$ a $8^{\mathrm{a}}$ série foram de $\mathrm{R} \$ 228,50$ na zona rural e $\mathrm{R} \$ 443,14$ na zona urbana. Os professores de São Paulo recebiam um rendimento maior, sendo que, para quem trabalhava com crianças de $1^{\mathrm{a}}$ a $4^{\mathrm{a}}$ série, esse valor chegou a $\mathrm{R} \$ 360,00$ na zona rural e R\$ 873,37 na zona urbana. Essas diferenças aumentam quando se trata de professores que lecionavam de $5^{\mathrm{a}}$ a $8^{\mathrm{a}}$ série, pois os salários foram de $\mathrm{R} \$ 713,70$ para a zona rural e R\$ 735,92 para a zona urbana.

Através das informações do FNDE, é possível verificar, ainda, que a despesa corrente média por estudante no ano de 1999, para o Brasil, foi de R\$551,33, sendo que o estado de São Paulo apresentou o maior investimento por aluno naquele ano, chegando a R\$ 898,40. O estado de Pernambuco, por sua vez, encontrava-se entre os estados com menor despesa corrente por aluno/ano, a qual foi de R\$363,35, em 1999.

As informações acima levam a questionar até que ponto as iniciativas que melhoram a infra-estrutura escolar, como o volume total de investimentos para a educação e o salário mensal recebido pelos professores, estão influenciando as alterações no número total de matrículas e no resultado escolar das crianças do ensino fundamental nos dois estados. Além disso, outros fatores econômicos e sociais podem estar influenciando a decisão de estudar e o atraso escolar do aluno. Dentre esses podem ser citados a escolaridade dos pais e a renda familiar per capita. Questiona-se, também, se é mais interessante para o governo investir na melhoria da qualidade das escolas ou em iniciativas que melhoram as condições socioeconômicas da família da criança, como forma de atrair os alunos à escola e/ou reduzir a defasagem escolar do ensino fundamental. Logicamente, é importantíssimo que se eleve a qualidade das escolas, mas é também fundamental que se entenda quais são as formas mais eficientes de se colocar e manter as crianças nas escolas, garantindo-lhes um aprendizado adequado e a progressão contínua nos estudos. Programas de transferência de renda, como o "bolsaescola”, que foi incorporado ao "bolsa-família”, poderiam ser substituídos, pelo menos em parte, por melhorias na qualidade do ensino, caso fosse confirmado que o efeito da melhoria da qualidade das escolas é maior do que a elevação da renda da família para aumentar a freqüência escolar. Além disso, maiores investimentos poderiam ser feitos 
em programas de "Educação de jovens e adultos" se houvesse evidências de que a educação dos pais é fator preponderante no interesse educacional dos filhos. Essas questões são alguns dos objetivos do presente estudo.

\subsection{Objetivos}

\subsubsection{Objetivo geral}

O presente estudo propõe-se a avaliar os impactos de variáveis associadas à melhoria na qualidade das escolas e de variáveis que representam as características individuais e familiares da criança, sobre a freqüência e o atraso escolar em nível fundamental, de escolas públicas, nos estados de São Paulo e Pernambuco.

\subsubsection{Objetivos específicos}

Investigar as interações entre variáveis das características familiares e variáveis de qualidade e infra-estrutura escolar, a fim de fornecer subsídios quanto à melhor alocação dos recursos econômicos disponíveis.

Realizar simulações para avaliar os impactos de um aumento na melhoria da qualidade das escolas, versus uma melhoria das condições socioeconômicas das famílias.

\subsection{Hipótese}

Dadas as diferenças regionais e socioeconômicas entre São Paulo e Pernambuco, acredita-se que os resultados evidenciarão que, em Pernambuco, aumentar a renda das famílias e/ou a escolaridade da pessoa responsável pela criança seja mais 
importante para elevar a freqüência e reduzir o atraso escolar das crianças, do que aumentar a qualidade das escolas, ocorrendo o contrário em São Paulo. Além disso, supõe-se que os resultados da pesquisa poderão auxiliar a tomada de decisão de dirigentes governamentais, quanto à implementação de seus programas sociais.

\subsection{Estrutura do trabalho}

O presente estudo está dividido em seis capítulos, nos quais está incluída essa introdução que aborda os objetivos, a justificativa do estudo e sua hipótese. No capítulo 2 é feita uma ligeira discussão das diferenças inter-regionais do Brasil, além de um levantamento histórico sobre as mudanças recentes ocorridas nas políticas educacionais brasileiras. O terceiro capítulo faz uma revisão da literatura que discutiu os fatores determinantes da busca por escolaridade e do desempenho escolar. A descrição das bases de dados que foram usadas no trabalho e o modelo econométrico escolhido para tal fim podem ser vistos no capítulo 4. Para o capítulo 5 reservou-se espaço para analisar e discutir os resultados encontrados nesse trabalho e finalmente, no capítulo 6, são comentadas as conclusões, tendo em vista os resultados finais da pesquisa. 


\title{
2 FATORES RELACIONADOS A DIFERENÇAS REGIONAIS E POLÍTICAS EDUCACIONAIS
}

\author{
"Então procurarás o Senhor, teu Deus, e o encontrarás, \\ Contanto que os busques de todo o teu coração e de toda a tua alma.”
}

(Deuteronômio 4:29)

Esse capítulo está dividido em dois tópicos que foram distribuídos de forma a contemplar as discussões envolvendo análises comparativas regionais no território brasileiro, bem como as evoluções recentes ocorridas na área da educação.

O primeiro tópico apresenta uma breve revisão da literatura nacional que se preocupou em realizar comparações regionais do crescimento econômico brasileiro, tendo em vista as disparidades de renda que se fortaleceram ao longo do tempo. Em um subitem apresentam-se algumas estatísticas comparativas dos estados de Pernambuco e São Paulo.

No segundo tópico serão avaliadas as mudanças ocorridas no sistema educacional brasileiro durante a década de 1990, as quais contemplam normas legislativas e alterações no sistema de financiamento da educação. Aqui, também, foi incluído um subitem, no qual é comentada a preocupação com a distorção idade-série 
do sistema de ensino brasileiro, além das iniciativas já existentes no sentido de contornar esse problema.

\subsection{Abordagens recentes das diferenças regionais do Brasil}

As diferenças econômicas regionais do Brasil tem sido foco de diversos estudos, os quais tentam, por um lado, fazer o levantamento de indicadores socioeconômicos que permitam visualizar a dimensão dessas diferenças, além das causas de sua existência. Por outro lado, sugerem políticas públicas capazes de diminuir, ou até mesmo eliminar tal situação.

Um levantamento histórico das desigualdades regionais no espaço brasileiro ressalta que:

“...a ocupação e o povoamento do Brasil se deram por meio de surto de atividades exportadoras que, sucedendo-se ao longo do tempo, foram fixando populações em diferentes pontos do território nacional. E, conforme o sucesso ou insucesso da exploração econômica - em particular, a capacidade ou incapacidade de levar à diversificação e à industrialização - estabeleceram-se diferenciações nítidas entre esses focos isolados de civilização, bem retratadas nos indicadores econômicos e sociais, consagrando a herança regional do desenvolvimento do País”. (Brasil, 1993, p.14)

Esse estudo relata, ainda, que os governos militares brasileiros preocuparam-se em incentivar um crescimento econômico acelerado para o país, no 
qual a eficiência prevalecia sobre a equidade. Desse modo, a região Sudeste recebeu a maior parcela dos investimentos financeiros internacionais, consolidando-se como matriz produtiva nacional, numa realidade onde as demais regiões passaram a constituir-se dos elos subalternos.

Essa concretização de diferenças econômicas ocorridas entre a região Sudeste e as demais regiões do país levou, também, à existência de diferenças sociais, as quais podem ser percebidas nos indicadores educacionais, de renda per capita e de saúde, apresentados em alguns estudos econômicos.

Dados de 1970 mostram que, naquele ano, a região Sudeste respondia por 64,5\% da renda nacional, mantendo a maior concentração populacional do país (42,7\%). A região Nordeste, no entanto, apesar de responder pelo segundo maior contingente populacional (30,3\%), detinha apenas 12,2\% da renda nacional, ficando atrás da região Sul (Wood \& Carvalho, 1994). Ao comparar os anos de 1970 e 1980, esses autores demonstraram que em diversos indicadores sociais, como taxas de alfabetização, população com água encanada, esgoto ou eletricidade, o Nordeste apresentava condições bastante precárias, quando comparado ao Sudeste.

Uma comparação entre os anos de 1981 e 1990 mostrou que a proporção de pessoas pobres ${ }^{1}$ na região Nordeste aumentou de 42,8\% em 1981, para 44,9\% em 1990, sendo que essa região se destacava como a mais pobre do país. O Sudeste, nesse caso, apresentou-se como a região com menor porcentagem de pobres, que era de 12,1\% em 1981 e de 12,0\% em 1990. Esse trabalho assinalou, ainda, que a esperança de vida ao nascer da região Nordeste (que era de 55,6 anos em 1984), sempre se manteve num nível inferior ao da região Sul (71,4 anos em 1984), entre os anos de 1960 e 1984 (Hoffmann, 1997).

${ }^{1} \mathrm{O}$ cálculo referente à proporção de pessoas pobres foi feito para 5 grandes regiões do país (Norte, Nordeste, Sudeste, Sul e Centro-Oeste), adotando uma linha de pobreza de 1/4 do salário mínimo de outubro de 1981 per capita. 
Em uma análise sobre os atributos pessoais e a heterogeneidade do trabalhador por conta-própria, Machado (1993) fez uma comparação das regiões metropolitanas de Porto Alegre, São Paulo, Belo Horizonte e Recife, concluindo que as disparidades regionais desses quatro centros influenciavam no rendimento dos trabalhadores, de modo especial, nos grupos de rendimento mais elevado.

Com os dados da Pesquisa Nacional sobre Saúde e Nutrição (PNSN), realizada pelo IBGE em 1989, foi possível fazer uma nova análise da extensão da pobreza, bem como da fome e da desnutrição no Brasil. Verificou-se, para aquele ano, que a região Nordeste detinha 31,8\% dos indivíduos com renda inferior a 0,25 salários mínimos per capita, enquanto na região Sudeste viviam apenas 8,6\% dessas pessoas. Percebeu-se, também, que nas regiões Norte e Nordeste concentravam-se o maior número de crianças desnutridas, com estatísticas comparáveis a países muito pobres da América Latina e África. Enquanto isso, as regiões Sul, Sudeste e Centro-Oeste podiam ser comparadas a países relativamente ricos e/ou com sistemas de seguridade social eficazes (Monteiro, 1995).

Com as informações da PNSN foi possível, também, fazer uma análise da demanda por saúde infantil, separada por regiões (Nordeste e Sul/Sudeste/Central) e por situação de domicílio (urbano/rural). Os resultados mostraram que o índice de alfabetização era a variável mais importante em lugares pobres, como a região Nordeste e a área rural, tornando-se necessário investir em educação básica, a fim de melhorar a saúde das crianças (Kassouf, 1994).

A desigualdade de rendimentos entre as pessoas ocupadas na agricultura brasileira, em 1981 e 1990 foi estudada por Corrêa \& Hoffmann (1997), que concluíram que fatores como a posição ocupacional e nível educacional contribuíam de maneira significativa na explicação da desigualdade de rendimentos. Sugeriram, então, a adoção de políticas que levassem ao enfrentamento das disparidades regionais existentes no país. 
Alguns estudos foram desenvolvidos com o objetivo de realizar uma análise comparativa dos indicadores educacionais. Dentre esses, pode-se citar: o trabalho realizado por Barros et al. (1999) que usou dados da PNAD, cobrindo o período de 1981 a 1996. Ao fazer uma avaliação do desempenho do ensino médio brasileiro $^{2}$, os autores perceberam grandes disparidades regionais, de modo especial, entre as regiões Sudeste e Nordeste, visto que na primeira região apenas 15\% das pessoas não tiveram acesso à segunda etapa do ensino fundamental, enquanto na região Nordeste esse percentual girava em torno de 50\%. Detectaram, também, que a qualidade dos serviços educacionais apresentava uma situação bem mais precária na região Nordeste, em relação ao Sudeste, citando-se a distribuição gratuita do livro didático no ensino fundamental e a disponibilidade de equipamentos, de modo especial, computadores e vídeos. Enfim, mostraram que a região Sudeste concentrava um maior nível de gastos familiares com educação, quando comparada à região Nordeste.

Tem-se, ainda, a pesquisa de Castro (2000), a qual fez um relato do desempenho educacional brasileiro da década de 1990, concluindo que houve um ritmo diferenciado nos avanços educacionais de cada região brasileira, o que levou a um aprofundamento do grau de desigualdade regional. Dentre as estatísticas apresentadas pela autora tem-se a taxa de analfabetismo que, em 1996, tinha um percentual 2,7 vezes maior na região Nordeste, quando comparada com a região Sudeste. As taxas de repetência confirmavam essas disparidades regionais, visto que mais da metade dos alunos de $1^{\mathrm{a}}$ série era afetados pela repetência, nas regiões Norte e Nordeste, enquanto nas regiões Sul e Sudeste esses índices eram de 28\% e 25\%, respectivamente, no ano de 1995. Enquanto isso, a região Centro-Oeste apresentava um índice de repetência de 42\%. Além disso, a autora mostrou que apesar de investir um maior percentual do seu PIB per capita em educação, o gasto por aluno/ano da

${ }^{2}$ Os autores salientam que por educação média entende-se não somente a educação secundária, mas também o período que vai da $5^{\mathrm{a}}$ a $8^{\mathrm{a}}$ série do ensino fundamental. 
região Nordeste era bem inferior ao da região Sudeste, situação essa que comprovava as diferenças de poder econômico de cada região.

As pesquisas citadas acima confirmam, portanto, a necessidade de levar em conta as diferenças socioeconômicas existentes nas regiões brasileiras, no momento de adotar políticas econômicas que tenham como objetivo a melhoria dos indicadores sociais. O presente trabalho insere-se nesse contexto, ao pretender fazer um estudo comparativo entre os estados de Pernambuco e São Paulo, pertencentes às regiões Nordeste e Sudeste, respectivamente.

\subsubsection{Análise comparativa dos estados de Pernambuco e São Paulo}

Dentre os estados nordestinos, Pernambuco possui o segundo maior contingente populacional, contando com, aproximadamente, 7,9 milhões de pessoas e ficando atrás, somente da Bahia que tem em torno de 13 milhões de habitantes. Porém, a área desse estado corresponde a $98.938 \mathrm{~km}^{2}$, sendo inferior aos estados do Maranhão, Piauí e Ceará. Em função disso, Pernambuco possui 80,3 habitantes por $\mathrm{km}^{2}$, número, esse superior ao da Bahia e do Ceará. Sua participação no Produto Interno Bruto (PIB), em relação à região no ano 2000, foi de 20,21\%. Em relação ao Brasil, este Estado participou com 2,64\% do PIB. Seu potencial econômico concentrase na produção agrícola de mandioca, feijão, cana-de-açúcar e milho, além de possuir um extenso rebanho de bovinos e caprinos. No setor industrial Pernambuco destaca-se na transformação de minerais não metálicos, confecções, mobiliário e curtume. Contudo, seus setores de ponta são representados, dentre outros, pelos pólos médico, de informática e turístico (Governo do Estado de Pernambuco, 2003).

Observando a Tabela 1 é possível comparar alguns indicadores socioeconômicos de Pernambuco com os outros estados do Nordeste, a saber, a proporção de pobres, o índice de Gini e o IDH-M. O índice de Gini é uma medida usada para identificar o nível de concentração de renda em uma determinada 
população. Quando esse índice aproxima-se de zero, isso indica equidade e quando se aproxima de um, indica uma grande concentração de renda. Nos estados do Nordeste nota-se que, além da população pobre ser muito elevada, a renda também é muito concentrada. Todos os índices giram em torno de 0,6 e 0,7 e Pernambuco é o terceiro estado com a mais desigual distribuição de renda, ficando atrás somente de Alagoas e do Ceará.

Tabela 1. Indicadores socioeconômicos para os estados do Nordeste

\begin{tabular}{lccccc}
\hline Estado & $\begin{array}{c}\text { Número de } \\
\text { pobres (mil) }\end{array}$ & $\begin{array}{c}\text { Proporção de } \\
\text { pobres (\%) }^{1}\end{array}$ & $\begin{array}{c}\text { Índice de }_{\text {Gini }^{2}} \\
\text { IDH-M }^{3}\end{array}$ & $\begin{array}{c}\text { Ranking } \\
\text { no Brasil }^{3}\end{array}$ \\
\hline Alagoas & $1.405,8$ & 51,88 & 0,69 & 0,633 & 27 \\
Bahia & $6.159,1$ & 49,16 & 0,67 & 0,693 & 20 \\
Ceará & $3.696,5$ & 53,27 & 0,68 & 0,699 & 19 \\
Maranhão & $2.854,3$ & 52,98 & 0,66 & 0,647 & 26 \\
Paraíba & $1.468,6$ & 44,04 & 0,65 & 0,678 & 24 \\
Pernambuco & $4.013,0$ & 56,34 & 0,67 & 0,692 & 22 \\
Piaú & $1.454,6$ & 54,05 & 0,66 & 0,673 & 25 \\
Rio Grande do & & & & & \\
Norte & $1.099,0$ & 41,72 & 0,66 & 0,702 & 18 \\
Sergipe & 728,6 & 45,48 & 0,66 & 0,687 & 23 \\
\hline
\end{tabular}

Fontes: ${ }^{1}$ Rocha (2001) e ${ }^{2,3}$ IPEA (2003)

O Índice de Desenvolvimento Humano Municipal (IDH-M), é resultado de um estudo realizado e divulgado pelo Instituto de Pesquisa em Economia Aplicada (IPEA) juntamente com a Fundação João Pinheiro (MG) e o Programa das Nações Unidas para o Desenvolvimento (PNUD). A pesquisa foi realizada com as informações do Censo Demográfico 2000 e, quanto mais próximo de um for o IDH-M, melhores as condições de desenvolvimento socioeconômico de um município ou estado. Na tabela 1, além de aparecerem os resultados alcançados para os estados do Nordeste, também é informado o ranking desses estados, com relação ao total das Unidades da Federação brasileira. Pernambuco obteve um índice de 0,692, situando-se entre os estados com médio desenvolvimento humano e ficando em vigésimo segundo 
lugar. Os estados da Bahia e do Ceará estão mais bem classificados com um IDH-M superior ao de Pernambuco.

Com relação ao indicador de pobreza ${ }^{3}$, a Bahia possui o maior número absoluto de pobres (6,1 milhões de pessoas) e Pernambuco mantém o segundo maior contingente de pessoas nessa situação (4,0 milhões). Porém ao se observar os dados percentuais, percebe-se que em Pernambuco está concentrada a maior proporção de pobres, com relação ao total da população (56,34\%).

Percebe-se, portanto, que apesar de possuir um alto contingente populacional e uma expressiva participação no PIB de sua região, Pernambuco tem apresentado estatísticas preocupantes, quando se observa os indicadores sociais aqui selecionados. Justifica-se, assim, a escolha desse estado, dentre os outros estados da região Nordeste, para se realizar uma análise comparativa com o estado de São Paulo.

São Paulo destaca-se no cenário nacional como o estado que concentra o maior contingente populacional, tendo uma estimativa superior a 37 milhões de habitantes, numa área de 248.808,8 $\mathrm{km}^{2}$. Além disso, esse estado possui o maior parque industrial e a maior produção econômica do país. Como resultado desse desempenho, sua participação no PIB brasileiro foi de 33,67\% no ano 2000, sendo que o estado com a segunda maior participação foi o Rio de Janeiro, com 12,52\% do PIB. Com relação à região Sudeste, São Paulo destacou-se com uma participação de 58,27\% do PIB regional, segundo divulgação da Fundação Sistema Estadual da Análise de Dados (SEADE) (2003).

Com relação aos indicadores socioeconômicos, a Tabela 2 mostra que São Paulo possui o menor índice de Gini da região Sudeste, indicando que a concentração de renda é relativamente baixa nesse estado.

\footnotetext{
${ }^{3}$ Os indicadores obtidos no trabalho de Rocha (2001) baseiam-se em linhas de pobreza derivadas da Pesquisa de Orçamentos Familiares (POF) de 1987/1988 e assumem valores entre 1/4 e 2 salários mínimos. A autora afirma que as diferenças nos padrões de consumo e nos preços ao consumidor, entre as regiões, foram levadas em consideração.
} 
Na classificação do IDH-M, São Paulo aparece como o segundo estado com alto desenvolvimento humano, apresentando um índice de 0,814, superado apenas pelo Distrito Federal. Apesar de ter obtido um bom desempenho nesses dois índices, a proporção de pobres no estado de São Paulo ainda é elevada (29,35\% da população), sendo inferior somente ao estado de Minas Gerais, com 29,37\%.

Tabela 2. Indicadores socioeconômicos para os estados do Sudeste

\begin{tabular}{lccccc}
\hline Estado & $\begin{array}{c}\text { Número de } \\
\text { pobres (mil) }\end{array}$ & $\begin{array}{c}\text { Proporção de } \\
\text { pobres (\%) }\end{array}$ & $\begin{array}{c}\text { Índice de } \\
\text { Gini }^{2}\end{array}$ & $\begin{array}{c}\text { IDH-M3 } \\
\text { Ranking } \\
\text { Espírito Santo }\end{array}$ no5,7 $^{3}$ Brasil $^{3}$ \\
Minas Gerais & $4.970,5$ & 24,24 & 0,61 & 0,767 & 10 \\
Rio de Janeiro & $3.706,6$ & 27,88 & 0,62 & 0,766 & 11 \\
São Paulo & $10.217,3$ & 29,35 & 0,61 & 0,802 & 5 \\
\hline
\end{tabular}

Fontes: ${ }^{1}$ Rocha (2001) e ${ }^{2,3}$ IPEA (2003)

Dado que o objetivo desse trabalho é realizar estimativas para variáveis de escolaridade, far-se-á, a partir de agora, uma breve análise comparativa de alguns indicadores educacionais, entre os estados de Pernambuco e São Paulo.

Os indicadores da Tabela 3 revelam as diferenças existentes entre esses dois estados, na área da educação. A média de anos de estudo, para a população de 15 anos ou mais, em Pernambuco, foi de 5,4 anos no ano 2001, a qual se situou abaixo da média brasileira, que foi de 6,4 anos, enquanto São Paulo apresentava uma média de 7,6 anos de estudo. Castro (2000) salienta que a taxa de analfabetismo é comumente usada para evidenciar o atraso educacional de um país, especialmente em análises internacionais. Em 2001, quando a taxa média de analfabetos do Brasil era de 12,4\%, Pernambuco mantinha um índice de analfabetismo de 22,0\% em sua população de 15 anos ou mais, com um percentual 3,6 vezes maior que o de São Paulo, de 6,0\%. 
Tabela 3. Indicadores de desempenho educacional nos estados de Pernambuco e São Paulo

\begin{tabular}{|c|c|c|c|}
\hline Estado & $\begin{array}{c}\text { Média de Anos de } \\
\text { Estudo }^{1} \\
\text { Em } 2001 \\
\end{array}$ & $\begin{array}{c}\text { Taxa de } \\
\text { Analfabetismo }^{2} \\
\text { em } 2001\end{array}$ & $\begin{array}{c}\text { Taxa de Repetência }{ }^{3} \\
\text { em } 2000\end{array}$ \\
\hline Pernambuco & 5,4 & 22,0 & 29,6 \\
\hline São Paulo & 7,6 & 6,0 & 7,3 \\
\hline
\end{tabular}

Fontes: ${ }^{1,2}$ IBGE (2001) e ${ }^{3}$ Brasil (2004)

1,2 para a população de 15 anos ou mais

${ }^{1}$ indica o número máximo de séries concluídas

${ }^{3}$ percentuais do ensino fundamental

A taxa de repetência é dada pela média de alunos que não conseguiram passar para a série seguinte, nas oito séries do ensino fundamental. No que se refere a esse indicador, no ano 2000 Pernambuco tinha um índice 4,05 vezes superior ao de São Paulo, pois $29,6 \%$ de seus alunos do ensino fundamental foram reprovados, enquanto o índice de reprovação dos estudantes paulistas foi de 7,3\%. Essa diferença pode também estar associada às políticas educacionais adotadas nos dois estados, pois no ano 2000 São Paulo já vinha adotando o regime de progressão continuada nas quatro primeiras séries do ensino fundamental ${ }^{4}$.

Atualmente, um indicador de qualidade educacional utilizado pelo MEC diz respeito aos levantamentos divulgados pelo Sistema de Avaliação do Ensino Básico (Saeb). Esse sistema foi implantado em 1990, com o objetivo de coletar dados sobre o processo de ensino aprendizagem para as $4^{\mathrm{a}}$ e $8^{\mathrm{a}}$ séries do ensino fundamental, bem como para o $3^{\text {a }}$ ano do ensino médio. Pretende-se, portanto, que os resultados divulgados pelo exame Saeb sejam usados pelas secretarias estaduais e municipais de educação para corrigir distorções e debilidades identificadas no sistema, através de apoio técnico e financeiro às escolas e níveis educacionais mais necessitados. Além

${ }^{4}$ Maiores explicações associadas ao regime de progressão continuada estão no item 2.2.1 desse trabalho. 
disso, os levantamentos divulgados pelo Saeb servem de parâmetro para detectar as diferenças regionais ocorridas no sistema educacional como um todo.

O desempenho atingido pelas crianças nesse exame é dividido em níveis de conhecimento, sendo que, para a $4^{\mathrm{a}}$ série do ensino fundamental, o nível 1 identifica um desempenho muito crítico e a criança não foi alfabetizada adequadamente e não domina comandos matemáticos elementares. No nível 2 o resultado apresentado pela criança é crítico e ela lê de forma truncada ou resolve problemas matemáticos muito simples. Nos níveis 3 e 4 os conhecimentos adquiridos ainda estão aquém do desejado. O nível 5 é o adequado e no nível 6 a criança tem habilidades mais consolidadas e, algumas vezes, além do esperado.

A Tabela 4 mostra a média obtida no Brasil, assim como nos estados de Pernambuco e São Paulo, no exame de 2001. Na disciplina de matemática os alunos brasileiros da $4^{\text {a }}$ série do ensino fundamental obtiveram média 176,3, a qual está localizada no nível 3 da escala de desempenho do exame Saeb. Nessa mesma escala, encontram-se as crianças paulistas, com média 190,8. Enquanto isso, os estudantes de Pernambuco estão situados em um nível inferior 2, com um desempenho médio de 159,1 .

Tabela 4. Média de desempenho no exame SAEB, na $4^{\mathrm{a}}$ e $8^{\mathrm{a}}$ séries do ensino fundamental, para o ano 2001: disciplinas de português e matemática

\begin{tabular}{lcccc}
\hline \multirow{2}{*}{ Estado } & \multicolumn{2}{c}{$4^{\text {a }}$ série } & \multicolumn{2}{c}{$8^{\text {a }}$ série } \\
& Matemática & Português & Matemática & Português \\
\hline Brasil & 176,3 & 165,1 & 243,4 & 235,2 \\
Pernambuco & 159,1 & 149,1 & 226,0 & 217,8 \\
São Paulo & 190,8 & 180,4 & 247,1 & 237,2 \\
\hline
\end{tabular}

Fonte: Brasil (2002) 
O desempenho obtido no país como um todo em língua portuguesa situa-se no nível 2 da escala Saeb, com média de 165,1. O estado de Pernambuco enquadra-se entre os estados com a pior classificação, estando no nível 1 e apresentando uma média de 149,1. São Paulo, por sua vez, destaca-se como um dos estados com melhor desempenho, tendo obtido média 180,4 e permanecendo no nível 3.

A Tabela 4 apresenta, também, os resultados obtidos pelos alunos da $8^{\text {a }}$ série do ensino fundamental, sendo que os níveis de conhecimento são um pouco diferentes. Nos níveis 1 e 2 o conhecimento adquirido não é sequer compatível com a $4^{\mathrm{a}}$ série do ensino fundamental. Os níveis 3 e 4 representam um desempenho crítico e os alunos ainda não são bons leitores e tem dificuldades com interpretação de problemas. Os níveis 5 ou 6 são considerados intermediários e os níveis 7 ou 8 são os adequados, nos quais a criança sabe resolver um problema e interpreta um texto eficientemente. No nível 9 a criança apresenta habilidade em um nível superior ao da série para a qual está sendo avaliada.

Percebe-se que as médias obtidas pelas crianças avaliadas na $8^{\mathrm{a}}$ série foram superiores aos alunos da $4^{\mathrm{a}}$ série. Em língua portuguesa, tanto a média brasileira $(235,2)$, quanto às médias de Pernambuco e São Paulo estão localizadas no nível 4 da escala Saeb. No entanto, nota-se que o estado de Pernambuco, com uma média de 217,8 posiciona-se num patamar inferior ao da média nacional, enquanto São Paulo apresentou um desempenho ligeiramente superior $(237,2)$. Com relação à disciplina de matemática, as médias situaram-se, mais uma vez, no nível 4, voltando a confirmar-se um resultado superior para São Paulo $(247,1)$, comparativamente ao estado de Pernambuco, cujo desempenho foi de 226,0. Para o Brasil, a média obtida foi de 243,4 .

Cabe aqui ressaltar a preocupação externada nos documentos do MEC, com relação à influência exercida pelas condições socioeconômicas no desempenho educacional de crianças do ensino fundamental. Quando uma criança freqüenta escola com péssimas condições de infra-estrutura, desprovida de bibliotecas, laboratórios de 
informática e ciências, bem como de professores qualificados e bem remunerados, seu resultado, provavelmente será inferior ao desejado em um exame de habilidades.

Acredita-se, portanto, que as diferenças regionais existentes no país levem diferentes variáveis a provocar maior ou menor impacto na decisão familiar de buscar a escolarização, bem como no desempenho escolar dos alunos. Em vista disso, uma avaliação comparativa dos estados de Pernambuco e São Paulo, poderá contribuir com a adoção de políticas públicas que busquem equalizar o sistema de ensino brasileiro.

\subsection{Mudanças recentes dos investimentos em educação no Brasil}

A taxa de expansão do sistema educacional brasileiro tem sido considerada historicamente baixa, especialmente, quando comparado com países asiáticos e latinoamericanos que tiveram taxas de crescimento econômico iguais ou maiores do que as do Brasil, ao longo das últimas décadas.

Dentre os indicadores comumente utilizados para se fazer análise comparativa entre os países tem-se o Índice de Desenvolvimento Humano (IDH), cujas informações referentes ao ano 2002 foram publicadas pelo Programa das Nações Unidas para o Desenvolvimento (PNUD). Na Tabela 5 é possível verificar a classificação obtida pelo Brasil, comparativamente a outros países da América Latina, a partir de uma lista de 175 países. O índice é obtido combinando medidas de renda, saúde e educação, cabendo aqui ressaltar o desempenho do Brasil em relação à taxa de alfabetização e ao percentual dos gastos com educação em relação ao PNB. 
Tabela 5. Índice de desenvolvimento humano e indicadores educacionais: Brasil e países da América Latina - 2002

\begin{tabular}{lccc}
\hline País & $\begin{array}{c}\text { Ordenação } \\
\text { IDH }\end{array}$ & $\begin{array}{c}\text { Taxa de } \\
\text { alfabetização }\end{array}$ & $\begin{array}{c}\text { Gastos em educação. } \\
\text { \% do PNB } \\
1998-2000^{2}\end{array}$ \\
\hline Argentina & 34 & 96,9 & 4,0 \\
Uruguai & 40 & 97,6 & 2,8 \\
Costa Rica & 42 & 95,7 & 4,4 \\
Chile & 43 & 95,9 & 4,2 \\
Cuba & 52 & 96,8 & 8,5 \\
México & 55 & 91,4 & 4,4 \\
Colômbia & 64 & 91,9 & - \\
BRASIL & 65 & 87,3 & 4,7 \\
Venezuela & 69 & 92,8 & - \\
Peru & 82 & 90,2 & 3,3 \\
Bolívia & 114 & 86,0 & 5,5 \\
\hline
\end{tabular}

Fonte: PNUD (2002)

${ }^{1}$ taxa de alfabetização de adultos (15 anos de idade ou mais)

2 os dados referem-se ao ano mais recente durante o período especificado

No que diz respeito ao percentual gasto com educação em relação ao PNB, o Brasil vem mantendo a mesma média da maioria dos países latino-americanos, tendo, inclusive apresentado investimentos superiores ao de países melhor classificados no IDH, como Argentina, Uruguai e Chile. Com relação à taxa de alfabetização de adultos, no entanto, o Brasil apresenta um índice de 87,3\%, inferior ao da Venezuela e Peru, os quais são países classificados abaixo de sua posição no IDH. Esse resultado contrasta, também, com os outros países aqui relacionados, os quais obtiveram médias de alfabetização superiores a 90\%.

Se nesse início da década de 2000 o Brasil apresenta um quadro educacional com necessidade de melhorias em seus indicadores, durante a década de 1990, resultados similares aos apresentados na tabela 5 eram fontes de constantes discussões entre pesquisadores e formuladores de políticas públicas. Essas pessoas afirmavam que o Brasil não gasta pouco com educação, logo o fraco desempenho 
apresentado pelo sistema educacional deveria estar ocorrendo em função da ineficiência na alocação de recursos (Castro \& Menezes, 2003).

Barros \& Mendonça (1998) afirmam que desde o início da década de 1980 o sistema público de ensino brasileiro já vinha tendo inovações em suas formas de gestão. Tidas como pequenas iniciativas em meio à necessidade de grandes reformas, essas mudanças eram impulsionadas pelo surgimento e crescimento da demanda por gestões mais democráticas, participativas e descentralizadas, a qual partia, especialmente, de professores e técnicos em educação.

Os autores dizem, também, que a promulgação da constituição federal de 1988 representou um avanço para a sociedade, ao introduzir diversas mudanças legais, conferindo maior autonomia e descentralização ao ensino. Dentre essas, consta a reforma tributária, que ampliou o repasse de recursos da união para estados e municípios. No que se refere ao financiamento do ensino, a constituição determina que o governo federal deve aplicar, no mínimo, $18 \%$ de suas receitas em impostos e transferências para a manutenção e desenvolvimento do ensino, enquanto os governos estaduais e municipais obrigam-se a aplicar ao menos $25 \%$.

Foi a partir da metade da década de 1990, entretanto, que se impulsionou e levou-se adiante, de forma efetiva, diversas mudanças no setor educacional brasileiro, cabendo destacar a alteração de normas legais, assim como os critérios para o financiamento da educação.

Em 1996 foi aprovada a Lei $n^{\circ}$ 9.394, denominada Lei de Diretrizes e Bases da Educação Nacional, a qual instituiu como dever do Estado com a educação escolar pública a garantia de ensino fundamental, obrigatório e gratuito, inclusive para os que a ele não tiveram acesso na idade própria. Além disso, a lei previa que os diferentes sistemas de ensino deveriam definir normas de gestão democrática para o ensino público da educação básica. 
O governo federal tinha como estratégia, ainda, priorizar o ensino fundamental e reafirmar o papel do MEC enquanto coordenador das políticas nacionais. Nesse sentido, foi criado pela Emenda Constitucional $n^{0} 14$, de 12 de setembro de 1996 e regulamentado pela Lei 9.424, de 24 de dezembro de 1996, bem como pelo Decreto $n^{\circ}$ 2.264, de 27 de junho de 1997 o Fundo de Manutenção e Desenvolvimento do Ensino Fundamental e de Valorização do Magistério (FUNDEF), o qual consiste em um fundo contábil que subvincula uma parcela dos recursos disponíveis nas três esferas de governo para o Ensino Fundamental.

Os recursos originários de Estados e Municípios são constituídos de 15\% do:

- Fundo de Participação dos Estados - FPE;

- Fundo de Participação dos Municípios - FPM;

- Imposto sobre Circulação de Mercadorias e Serviços - ICMS (inclusive os recursos relativos à desoneração de exportações, de que trata a Lei Complementar $\left.n^{\circ} 87 / 96\right) ; e$

- Imposto sobre Produtos Industrializados, proporcional às exportações IPIexp.

Segundo Negri (1997), o critério de partilha e transferência de recursos para o FUNDEF inclui uma variável educacional, que é o número de alunos do ensino fundamental (regular e especial) atendidos pelo Estado e pelos Municípios, de acordo com o Censo Escolar do ano anterior, realizado pelo MEC. Essa iniciativa motivou o aumento da matrícula inicial no ensino fundamental, sob a responsabilidade dos municípios, pois quanto maior o contingente de alunos assumidos nesse nível de governo, tanto maior será o repasse a que o município tem direito.

Além do acima exposto, a Lei $n^{0}$ 9.424/96 prevê que a contribuição do governo federal ocorre a título de complementação, a fim de assegurar um valor 
mínimo de recursos por aluno/ano em todos os municípios e unidades da federação onde esse limite não for alcançado. Para calcular o valor mínimo por aluno/ano a metodologia utilizada pelo MEC, até o presente momento, leva em conta a receita e o número de alunos em cada estado, bem como no Distrito Federal, isoladamente. Assim, são encontrados 27 valores per capitas distintos. O valor mínimo nacional é fixado, a critério do Governo Federal, em um valor intermediário, entre o menor e o maior dos 27 per capitas calculados (MEC, 2003).

A Tabela 6 mostra os valores mínimos fixados entre os anos de 1997 e 2002, bem como o Decreto Federal que possibilitou a fixação do valor, lembrando que em 1997 esse valor foi estabelecido pela própria lei que regulamentou o FUNDEF. Ressalta-se, ainda, que a partir de 2000 a fixação passou a ocorrer definindo-se valores diferenciados para a $1^{\mathrm{a}}$ a $4^{\mathrm{a}}$ série e $5^{\mathrm{a}}$ a $8^{\mathrm{a}}$ e Educação Especial. No ano 2002 os estados da Bahia, Maranhão, Pará e Piauí receberam complementação da União para os recursos do FUNDEF.

Tabela 6. FUNDEF: valor mínimo nacional por aluno/ano - 1997 - 2002 (em R\$)

\begin{tabular}{ccccc}
\hline ANO & $1^{\mathrm{a}}$ a $4^{\mathrm{a}}$ série & $\begin{array}{c}5^{\mathrm{a}} \text { a } 8^{\mathrm{a}} \text { série e } \\
\text { Ed. Especial }\end{array}$ & $1^{\mathrm{a}}$ a $8^{\mathrm{a}}$ série & Ato legal de fixação do valor \\
\hline 1997 & & & 300,00 & $\begin{array}{c}\text { Art. } 6^{0}, \S 4^{\mathrm{o}}, \text { Lei } 9.424-24 / 12 / 96 . \\
\text { Dec. } 2.440 \text {, de } 23 / 12 / 1997 .\end{array}$ \\
1998 & & 315,00 & Dec. 2.935 , de $11 / 01 / 1999$. \\
1999 & & 315,00 & Dec. 3.326, de $31 / 12 / 1999$. \\
2000 & 333,00 & 349,65 & & Dec. 3.742, de $01 / 02 / 2001$. \\
2001 & 363,00 & 381,15 & & Dec. 4.103 , de $24 / 01 / 2002$. \\
\hline
\end{tabular}

Fonte: Brasil (2003)

Cabe salientar que a aplicação dos recursos do FUNDEF não isenta o município de destinar 15\% das demais receitas de impostos e transferências, não incluídas no Fundo, na manutenção e desenvolvimento do Ensino Fundamental. Além 
disso, é mantida a obrigatoriedade de o município aplicar, no mínimo, 25\% das receitas de impostos e transferências na educação.

De acordo com Castro et al. (2000), uma vez transferindo a responsabilidade pela oferta do ensino fundamental a estados e municípios, a partir de 1995, o governo federal pode reforçar o papel do MEC como coordenador da política nacional na área da educação, exercendo as funções normativa, redistributiva e supletiva. Nesse aspecto, destaca-se o trabalho do Fundo Nacional de Desenvolvimento da Educação (FNDE), o qual tem sido o órgão responsável pela política de assistência ao educando e financiamento do ensino básico.

Dentre os programas sob a responsabilidade do FNDE destacam-se o Programa Nacional de Alimentação Escolar (PNAE), Programa Dinheiro Direto na Escola (PDDE), Programa Nacional do Livro Didático (PNLD), Programa Nacional de Transporte Escolar (PNTE), Aceleração de Aprendizagem, TV e Rádio Escola, Fundescola, Educação de Jovens e Adultos e Desenvolvimento da Educação Especial. Os dois primeiros programas aqui citados serão comentados com maiores detalhes, em função da abrangência dos mesmos e dos propósitos desse trabalho.

O Programa Nacional de Alimentação Escolar (PNAE) é mais conhecido como Merenda Escolar e tem por objetivo “suprir, parcialmente, as necessidades nutricionais dos alunos, durante sua permanência na escola” (Brasil, 2001, p.97). Tendo sido criado no início da década de 1990, esse programa passou por várias experiências de gestão centralizada e descentralizada e, atualmente, tem transferido recursos a estados, municípios e Distrito Federal, a fim de que os mesmos garantam, no mínimo, uma refeição diária equilibrada às crianças atendidas no ensino básico.

O Programa Dinheiro Direto na Escola (PDDE) foi implantado em 1995 sob a denominação Programa de Manutenção e Desenvolvimento do Ensino Fundamental (PMDE) e tem como objetivo "transferir recursos financeiros diretamente às escolas públicas do Ensino Fundamental das redes estadual, municipal e do Distrito Federal, garantindo-lhes meios para as condições mínimas de 
funcionamento, ...de modo a concorrer para a promoção da elevação da qualidade do ensino por elas ministrado" (Brasil, 2001, p.92). Cabe ressaltar que as unidades escolares beneficiadas pelo PDDE recebem a verba do Governo Federal através de conta corrente específica e devem utilizar os recursos em finalidades pré-definidas pelo programa.

A Tabela 7 mostra o número de alunos atendidos pelos programas PNAE e PDDE, no período de 1995 a 2002. Verifica-se que o número de alunos atendidos pelo PNAE cresceu 5,88\% entre 1995 e 1997, voltando a cair no ano de 1998. Cresceu novamente entre 1999 e 2001, ficando com um atendimento próximo ao de 1999 no ano de 2002. O crescimento no número de beneficiados foi de aproximadamente 10,9\% ao longo de todo período. Com relação ao PDDE, nota-se que esse programa atendeu mais de 31 milhões de alunos nos anos de 1996 e 2000, estabilizando-se entre 30 e 31 milhões de alunos nos anos de 2001 e 2002. Em vista disso, o crescimento no número de beneficiados foi de 8,7\%, entre 1995 e 2002.

Tabela 7. Número de alunos atendidos pelos programas PNAE e PDDE: Brasil - 1995 a 2002

\begin{tabular}{ccc}
\hline \multirow{2}{*}{ ANO } & \multicolumn{2}{c}{ Alunos atendidos } \\
& PNAE $^{1}$ & PDDE $^{2}$ \\
\hline 1995 & 33.262 .484 & 28.350 .229 \\
1996 & 30.499 .500 & 31.287 .583 \\
1997 & 35.219 .595 & 26.672 .800 \\
1998 & 33.350 .300 & 28.961 .218 \\
1999 & 36.902 .898 & 30.665 .933 \\
2000 & 37.116 .858 & 31.491 .575 \\
2001 & 37.137 .900 & 30.589 .908 \\
2002 & 36.881 .738 & 30.809 .581 \\
\hline
\end{tabular}

Fontes: ${ }^{1} 1995$ a 1998 Castro et al. (2000); 1999 a 2002 Brasil (2003)

2 Brasil (2003) 
Outra preocupação do MEC, em relação ao ensino fundamental no Brasil, diz respeito à melhoria da qualidade escolar. A Tabela 8 mostra o avanço obtido no número de escolas com bibliotecas e laboratórios de informática, dado o total de estabelecimentos do Brasil, entre os anos de 1999 e 2003. Observando os dois itens escolhidos para representar a infra-estrutura escolar, é possível perceber que o número de escolas em que houve investimento em infra-estrutura tem crescido ao longo do tempo.

Tabela 8. Número total de escolas e quantidade de escolas que apresentaram melhorias na infra-estrutura: Brasil - 1999 a 2003

\begin{tabular}{lccccc}
\hline Ano & $\begin{array}{c}\text { Total de } \\
\text { escolas }\end{array}$ & $\begin{array}{c}\text { Escolas com } \\
\text { biblioteca }\end{array}$ & $\begin{array}{c}\text { Proporção do } \\
\text { total } \\
\%\end{array}$ & $\begin{array}{c}\text { Escolas c/ } \\
\text { laboratórios } \\
\text { de informática }\end{array}$ & $\begin{array}{c}\text { Proporção do } \\
\text { total } \\
\%\end{array}$ \\
\hline 1999 & 183.448 & 43.123 & 23,5 & 14.104 & 7,7 \\
2000 & 181.504 & 45.221 & 24,9 & 16.173 & 8,9 \\
2001 & 177.780 & 45.106 & 25,4 & 17.773 & 9,9 \\
2002 & 172.508 & 46.935 & 27,2 & 20.356 & 11,8 \\
2003 & 169.075 & 48.839 & 28,9 & 23.064 & 13,6 \\
\hline
\end{tabular}

Fonte: Brasil (2004)

O número de escolas com biblioteca aumentou em 5,4 pontos percentuais, passando de 23,5\% do total de escolas no Brasil, para 28,9\%. O número de escolas com laboratórios de informática apresentou um crescimento percentual ainda maior, saindo de uma proporção de 7,7\% do total de estabelecimento de ensino em 1999 e chegando a 13,6\% em 2003.

Além do aumento na quantidade de escolas com bibliotecas e laboratórios de informática para seus alunos, o MEC, através do FNDE, tem mantido o Programa Nacional Biblioteca da Escola (PNBE) e o Programa Nacional de Informática na Educação (Proinfo).O PNBE visa a distribuição de obras literárias para as escolas públicas do Ensino Fundamental, a fim de estimular o hábito da leitura e provocar a 
difusão do conhecimento entre professores e alunos. Em 2002, esse programa adquiriu 21 milhões de livros, de 4,2 milhões de coleções, que seriam utilizados por alunos da $4^{\mathrm{a}}$ série, no ano de 2003 (Brasil, 2003).

O Proinfo objetiva "introduzir novas tecnologias de informação e comunicação nas escolas públicas do Ensino Fundamental e Médio” (Brasil, 2003, p.85). Para tanto, os professores são capacitados para atuar como multiplicadores em sala de aula, fazendo o uso combinado de recursos como computadores e meios de telecomunicação. As ações do Proinfo capacitaram 10.275 professores, de 943 escolas, em 2002. Além disso, foram adquiridos 8.278 equipamentos de informática.

Como pode ser visto, apesar das diversas discussões e críticas acima citadas sobre o sistema educacional brasileiro, as mudanças recentes nessa área foram implementadas como meta para melhorar a quantidade e a qualidade das escolas, especialmente nos níveis correspondentes ao ensino fundamental. Em função disso, vê-se a importância de incluir variáveis correspondentes à oferta de escolas em um modelo que busque analisar a freqüência escolar no ensino fundamental, a fim de verificar sua verdadeira influência em atrair e motivar os alunos.

\subsubsection{A preocupação com a defasagem escolar}

As informações acima descritas mostraram que as iniciativas do MEC, na década de 1990, concentraram-se na preocupação com a descentralização dos investimentos em educação e com a melhor utilização desses investimentos no ensino fundamental. Não obstante, tais iniciativas têm se deparado com um antigo problema brasileiro: os indicadores de qualidade da educação. No Brasil, os indicadores comumente utilizados para medir a qualidade educacional são as taxas de rendimento escolar, de distorção idade-série e a distorção idade-conclusão. 
De acordo com documento elaborado pelo MEC (Brasil, 2004) as taxas de reprovação e abandono são calculadas a partir de um percentual, com relação ao total de alunos matriculados no início do ano letivo. Desses, são tidos como reprovados os alunos que não preencheram os requisitos de aproveitamento escolar, ao passo que afastados por abandono são aqueles alunos que não obtiveram uma freqüência mínima na escola. A taxa de distorção idade-série identifica o percentual de alunos, em cada série, com idade superior à idade recomendada. Observando-se o total de alunos do ensino fundamental que estão nessa situação, tem-se uma média da distorção idadesérie para esse nível de ensino. Para se fazer o cálculo da distorção idade-conclusão, parte-se do princípio que a idade adequada para conclusão do ensino fundamental é de quinze anos. Nesse caso, são considerados com distorção idade-conclusão aqueles alunos que concluíram o ensino fundamental com idade acima da esperada.

A Tabela 9 mostra a evolução desses 4 índices, no Brasil, entre 1999 e 2003. Ao longo desse período a taxa de reprovação manteve-se entre $10 \%$ e $11 \%$, enquanto a taxa de abandono caiu de 11,3\%, em 1999 para 8,7\%, em 2002. Lembrando que essas duas taxas não foram apresentadas para o ano de 2003, pois o cálculo das mesmas será feito por ocasião das pesquisas referentes ao Censo Escolar de 2004.

Tabela 9. Taxas de rendimento escolar, distorção idade-série e distorção idadeconclusão do ensino fundamental: Brasil - 1999 a 2003

\begin{tabular}{ccccc}
\hline ANO & $\begin{array}{c}\text { Taxa de } \\
\text { reprovação }\end{array}$ & $\begin{array}{c}\text { Taxa de } \\
\text { abandono }\end{array}$ & $\begin{array}{c}\text { Distorção idade- } \\
\text { série }\end{array}$ & $\begin{array}{c}\text { Distorção idade- } \\
\text { conclusão }\end{array}$ \\
\hline 1999 & 10,4 & 11,3 & 44,0 & 47,4 \\
2000 & 10,7 & 12,0 & 41,7 & 45,7 \\
2001 & 11,0 & 9,6 & 39,1 & 44,5 \\
2002 & 11,7 & 8,7 & 36,6 & 41,5 \\
2003 & - & - & 33,9 & 39,1 \\
\hline
\end{tabular}

Fonte: Brasil (2004) 
A taxa de distorção idade-série apresentou uma queda de, aproximadamente, 10 pontos percentuais entre 1999 e 2003, caindo de 44\% para 33,9\%. A distorção idade-conclusão também diminuiu progressivamente, pois era de 47,4\% em 1999 e passou para 39,1\% em 2003.

Dos quatro itens acima descritos, o mais discutido e analisado na literatura sobre educação é a taxa de distorção idade-série, pois a mesma é uma conseqüência das taxas de reprovação e abandono escolar, além de uma causa da taxa de distorção idade-conclusão. Ferrão et al. (2002) afirmam que os prejuízos individuais e coletivos, bem como as soluções possíveis associadas à taxa de distorção idade-série têm sido muito discutidos na literatura. Além disso, o insucesso escolar está na origem desse problema tão complexo, provocando a perda da auto-estima do aluno e onerando o sistema público educacional (Prado, 2000).

Parente \& Luck (2004), por sua vez, dizem que o discurso do setor público, a respeito da melhoria desses indicadores, fortificou-se durante a década de 1990, mantendo-se como um dos principais temas da agenda social brasileira no início dessa década. Nesse aspecto, a LDB apresenta-se, novamente, como um marco regulatório das iniciativas do setor público, tendo em vista os artigos 23 e 24, assim especificados:

“A educação básica poderá organizar-se em séries anuais, períodos semestrais, ciclos, alternância regular de períodos de estudos, grupos não-seriados, com base na idade, na competência e em outros critérios, ou por forma diversa de organização, sempre que o interesse do processo de aprendizagem assim o recomendar" (LDB, cap. II, seção I, art. 23).

"V - a verificação do rendimento escolar observará os seguintes critérios: a) avaliação contínua e cumulativa do desempenho do aluno, com prevalência dos aspectos qualitativos sobre os quantitativos e dos resultados ao 
longo do período sobre os de eventuais provas finais; b) possibilidade de aceleração de estudos para alunos com atraso escolar; c) possibilidade de avanço nos cursos e nas séries mediante verificação do aprendizado; d) aproveitamento de estudos concluídos com êxito; e) obrigatoriedade de estudos de recuperação, de preferência paralelos ao período letivo, para os casos de baixo rendimento escolar, a serem disciplinados pelas instituições de ensino em seus regimentos” (LDB, cap. II, seção I, art. 24).

Desde então, as discussões teóricas sobre a questão da defasagem escolar foram, pouco a pouco, transformando-se em iniciativas práticas de combate a um problema tido como secular para o Brasil. Segundo Parente \& Luck (2004) os estados e municípios brasileiros ingressaram em ações para corrigir o fluxo escolar, como resposta às estratégias adotadas pelo MEC. A principal dessas estratégias foi a criação do programa de Aceleração de Aprendizagem que contou com a parceria do Instituto Ayrton Senna, da Petrobrás e do Banco Nacional para o Desenvolvimento Econômico e Social (BNDES), além do apoio técnico de diversas outras instituições. O apoio do MEC para estados e municípios tem ocorrido através da capacitação de professores, em cursos de 80 horas, que visam prepará-los para oferecer o atendimento especializado à clientela dessa ação. Além disso, são fornecidos materiais didáticopedagógicos específicos para os alunos inseridos nos programas (FNDE, 2003).

Parente \& Luck (2004) relatam, ainda, as experiências de outras instituições voltadas para a correção do fluxo escolar. O Centro de Estudos e Pesquisa em Educação, Cultura e Ação Comunitária (CENPEC) desenvolveu projetos em diversos municípios dos estados de São Paulo, Bahia, Ceará, Mato Grosso do Sul, Paraná e Rondônia. O Centro de Ensino Tecnológico de Brasília (CETEB) realizou 
ações em 371 municípios brasileiros, implantando uma proposta denominada "Pedagogia do Sucesso", que visa o resgate da auto-estima de professores e alunos envolvidos nas atividades diárias do projeto.

Além do acima exposto, Prado (2000) afirma que os sistemas de ensino têm procurado, gradativamente, adotar diferentes maneiras para corrigir a defasagem escolar. Dentre elas, tem-se o regime de ciclos e a promoção automática. Tendo em vista que um dos objetivos desse trabalho concentra-se na análise comparativa entre os estados de São Paulo e Pernambuco, será feito um breve relato das experiências vividas por esses estados.

Em Pernambuco, as diretrizes norteadoras do ensino fundamental estão devidamente registradas no Plano Estadual de Educação, que foi aprovado pela Lei Estadual $n^{\circ} 12.252$, de 08 de julho de 2002. Nesse plano, as principais metas ligadas à melhoria da defasagem são:

“i) Universalizar, com qualidade, o atendimento de toda a clientela do Ensino Fundamental do Estado, no prazo de cinco anos, garantindo o acesso, a permanência e o sucesso escolar de todas as crianças na escola, expandindo, gradativamente, o atendimento para nove anos de escolaridade fundamental; ii) Implantar, no prazo de cinco anos, gradativamente três ciclos no Ensino Fundamental, com a seguinte organização: $1^{\circ}$ ciclo, 6 - 8 anos; o $2^{\circ}, 9$-10 e o $3^{\circ}$ ciclo, 11 a 14 anos; iii) Reduzir o índice de distorção idade/série em 50\% em cinco anos, com redução progressiva até o final da década”. (Plano Estadual de Educação, 2002, p.16)

Para atingir os objetivos acima descritos, as principais iniciativas já implementadas pelo estado baseiam-se nos programas denominados "Se liga 
Pernambuco”, “Acelera Pernambuco” e “Alfabetizar com Sucesso”. Os dois primeiros programas foram implantados em parceria com o Instituto Airton Senna e prevêem a inserção de salas de aula com 25 alunos, a supervisão direta nas escolas e a adesão voluntária dos municípios. Os dois programas visam o atendimento de milhares de crianças e adolescentes, a fim de corrigir o fluxo de alfabetização e, conseqüentemente, a distorção idade-série do estado. Segundo informações da própria Secretaria Estadual da Educação 118 municípios aderiram ao programa "Se liga Pernambuco” e já começam a participar dos projetos específicos.

Uma vez corrigindo a defasagem escolar já existente é necessário criar mecanismos para evitar que as crianças ingressantes no sistema escolar enfrentem as mesmas dificuldades. Pensando nisso, a Secretaria Estadual da Educação de Pernambuco está implantando o programa “Alfabetizar com Sucesso” que pretende melhorar a qualidade do ensino nas séries iniciais do ensino fundamental $\left(1^{\mathrm{a}}\right.$ e $2^{\mathrm{a}}$ série), prevenindo o problema da repetência e do abandono e garantindo uma alfabetização bem-sucedida. Também, segundo informações dessa secretaria esse programa está envolvendo 1.831 professores e tem atingido um total de 49.111 alunos, de 520 escolas, inseridas em 116 municípios do estado. O programa visa, ainda, dar suporte à criação do $1^{\circ}$ ciclo do ensino fundamental e seus resultados efetivos poderão ser obtidos, sobretudo, no final de 2005, quando os alunos ingressantes no sistema terão concluído o ciclo.

O estado de São Paulo é tido como o pioneiro em implantação de programas de correção do fluxo escolar, tendo se inserido rapidamente nas propostas elaboradas em nível nacional e tendo realizado projetos próprios com esse objetivo. Neubauer (2000) afirma que o projeto “Classes de Aceleração” foi um dos primeiros a ser implantado no estado de São Paulo, em 1996 e seu objetivo fundamental é reverter a cultura da repetência. Para tanto, alunos multirrepetentes são conduzidos a um processo de aprendizagem acelerada, permitindo sua promoção para até duas séries mais à frente. Inicialmente, esse projeto foi difundido entre alunos de $1^{\mathrm{a}}$ a $4^{\mathrm{a}}$ série do ensino fundamental e vinha apresentando bons resultados até 1999, quando passou por 
um sistema de avaliação. A partir do ano 2000, seria posto em prática na rede paulista um outro projeto de aceleração, voltado para alunos de $5^{\mathrm{a}}$ a $8^{\mathrm{a}}$ série.

Uma das principais iniciativas da Secretaria Estadual da Educação (SEE) de São Paulo diz respeito ao Regime de Progressão Continuada, que foi instituído pela Deliberação CEE 09/97, em 30 de julho de 1997. Segundo esse regime o ensino fundamental de São Paulo pode ser organizado em um ou mais ciclos, com duração de oito anos. Para atender as recomendações dessa deliberação a maioria das escolas organizou-se em regime de dois ciclos, sendo que o primeiro compreende as turmas de $1^{\mathrm{a}}$ a $4^{\mathrm{a}}$ série e o segundo inclui as turmas de $5^{\mathrm{a}}$ a $8^{\mathrm{a}}$ série. A deliberação prevê, ainda, a avaliação contínua e cumulativa da aprendizagem do aluno, a fim de acompanhar o seu desempenho ao longo de todo ciclo; atividades de reforço e recuperação ao longo do processo e/ou no final do ciclo; meios alternativos de reforço, reclassificação, aproveitamento e aceleração de estudos; e controle da freqüência dos alunos (freqüência mínima de 75\%).

Tendo em vista o período a partir do qual o regime de progressão continuada está instalado e as possíveis conseqüências do mesmo na vida cotidiana das escolas, alguns estudos têm sido realizados com o objetivo de conhecer e avaliar a opinião dos atores envolvidos no processo. Neves \& Boruchovitch (2004) citam uma pesquisa realizada com 10.027 professores da rede estadual de ensino. A maioria dos entrevistados afirmou que esse regime não ajudou a melhorar as condições de ensino e aprendizagem dos alunos. Além disso, para 91,9\% dos professores a progressão de uma série para outra está ocorrendo sem que os alunos se apropriem dos conteúdos fundamentais. Quagliato (2003) afirma que o regime de progressão continuada chegou às escolas sem que houvesse uma discussão prévia das mudanças a serem instituídas. As escolas do ciclo I por ela estudadas mostraram-se preocupadas com a melhor forma de implantar o novo regime, enquanto as escolas do ciclo II pareceram não tomar conhecimento desse fato. Essa autora afirma, ainda, que a SEE deixou para as diretorias de ensino colocarem em prática as mudanças referentes ao novo regime. Com isso, as escolas tomaram a iniciativa de acordo com o entendimento que lhe foi 
possível. Uma das conseqüências desse processo é o fato de os alunos concluírem um ciclo de quatro anos sem os conhecimentos necessários para dar continuidade aos estudos. Bertagna (2003) reafirma a falta de diálogo e as dificuldades encontradas pelos professores na instauração dessas mudanças. Segundo essa autora a aprendizagem efetiva dos alunos depende de um contexto social mais amplo e suas possibilidades reais de sucesso/fracasso escolar estão correlacionadas às condições originais das famílias nas quais estão inseridos.

Na Tabela 10 é possível visualizar a evolução da distorção idade-série para os dois estados aqui analisados. Percebe-se que no estado de Pernambuco os percentuais são bem superiores aos de São Paulo, apresentando, muitas vezes o dobro de crianças com idade superior a desejada para sua série. Este resultado pode ser conseqüência das diferenças regionais já mencionadas nesse trabalho. Vê-se, também, que até o ano 2001 esse percentual correspondia a mais de 50\% das crianças matriculadas em Pernambuco, mas houve uma ligeira queda ao longo do período, ficando em $47 \%$ em 2003. O alto percentual desse índice pode estar ocorrendo porque no estado as iniciativas de combate à defasagem idade-série são bastante recentes e ainda não puderam apresentar os resultados desejados.

Tabela 10. Evolução da distorção idade-série no ensino fundamental dos estados de Pernambuco e São Paulo: 1999 a 2003

\begin{tabular}{ccc}
\hline \multirow{2}{*}{ Ano } & \multicolumn{2}{c}{ Distorção idade-série } \\
& Pernambuco & São Paulo \\
\hline 1999 & 55,8 & 22,6 \\
2000 & 54,0 & 19,1 \\
2001 & 52,5 & 15,8 \\
2002 & 50,1 & 13,6 \\
2003 & 47,1 & 12,2 \\
\hline
\end{tabular}

Fonte: Brasil (2004)

Em São Paulo, a defasagem idade-série apresentou quedas sucessivas ao longo do tempo, mas não pode ser eliminada pelas políticas adotadas no estado desde 
1996. Em 2003, 12\% dos alunos do ensino fundamental ainda cursava uma série não correspondente a sua idade, indicando a necessidade de esforço contínuo com relação a esse problema.

Recentemente, alguns estudos na área de economia têm se preocupado em avaliar os aspectos associados à defasagem escolar no Brasil. Dentre eles, Leon \& Menezes Filho (2002) apontam que diversos fatores podem influenciar o desempenho escolar de uma criança, os quais são representados por variáveis observadas e nãoobservadas. As variáveis observadas dizem respeito às condições socioeconômicas do estudante e sua família (idade, sexo, renda, etc.), bem como à situação social e econômica da região onde vive. As variáveis não-observadas estão ligadas ao talento, determinação e vontade de continuar estudando.

Além disso, as discussões acima relatadas evidenciaram a participação das políticas públicas nos esforços direcionados para combater o atraso escolar. Sendo assim, percebe-se a importância de entender melhor as inter-relações que envolvem o desempenho escolar de estudantes do ensino fundamental. O presente trabalho pretende contribuir com essa discussão, fazendo uma análise das variáveis associadas às características pessoais e familiares da criança, bem como dos fatores relacionados à qualidade da infra-estrutura escolar, verificando sua influência no atraso escolar de crianças que freqüentam o ensino fundamental dos estados de Pernambuco e São Paulo. 


\section{REVISÃO DE LITERATURA}

"o Senhor guardará os teus passos, agora e para todo o sempre.”

(Salmos 120:8)

A teoria do capital humano tem se constituído no principal embasamento teórico de estudos sobre escolaridade, tanto no que se refere aos retornos, quanto em relação ao aumento dos níveis educacionais procurados pelos indivíduos e famílias. Em função disso, o item 3.1 do presente capítulo apresentará alguns comentários sobre a teoria do capital humano e sua importância nas discussões econômicas, bem como o modelo de Becker-Tomes sobre investimento familiar em capital humano. O item 3.2 faz um apanhado da literatura que se preocupou em investigar os fatores relacionados com a melhoria dos níveis de escolaridade, com base no modelo Becker-Tomes. Para finalizar, o item 3.3 discute os trabalhos que incluíram variáveis das características da escola, nas estimativas de freqüência e desempenho escolar infantil.

\subsection{A teoria do capital humano}

Segundo Schultz (1973) os precursores da teoria econômica consideravam inconcebível incluir os investimentos em seres humanos como parte dos ganhos de capital de uma nação. Adam Smith, H. Von Thunen e Alfred Marshall fizeram breves 
comentários acerca das habilidades adquiridas pelo homem ao longo do tempo, sem contudo, incorporar essa discussão ao núcleo formal da ciência econômica. Partindo disso, o autor afirma que o capital humano é assim definido por ser parte do homem e, ao mesmo tempo, por representar uma fonte de satisfações ou rendimentos futuros.

Becker (1993), por sua vez, define investimentos em capital humano como as atividades que afetam o bem-estar e a renda futura das pessoas. Essas atividades incluem a escolaridade, treinamento no trabalho, cuidados médicos e informações sobre preço e salário, podendo diferir umas das outras, em relação ao montante investido e ao valor do retorno.

Das contribuições de Mincer (1974), ressalta-se a proposta de um modelo que estabelece uma relação funcional entre a obtenção de escolaridade e os rendimentos do trabalho. A partir de então, diversos estudos têm se baseado nesse modelo para analisar se o número de anos de escolaridade de um indivíduo é um indutor de diferenças salariais para os trabalhadores. Dado que o objetivo principal desse trabalho é avaliar os fatores que influenciam a obtenção de escolaridade e a defasagem escolar, serão comentados apenas alguns trabalhos, cujo objetivo foi analisar os retornos obtidos com maiores níveis de educação. Dentre esses, tem-se o trabalho de Card \& Krueger (1992) que analisaram a relação entre ganhos e qualidade escolar da escola pública nos Estados Unidos. Duflo (2001), por sua vez, avaliou os efeitos de um programa governamental na educação e na renda de pessoas nascidas entre 1950 e 1972 na Indonésia. No Brasil, Blom et al. (2002) investigaram a evolução dos retornos da educação, dadas as reformas políticas ocorridas no sistema educacional entre 1982 e 1998. Uma comparação dos rendimentos do trabalho, em função das diferenças de escolaridade, para as regiões Nordeste e Sudeste do Brasil foi feita por Pereira (2001).

Becker (1991) afirma que os economistas da teoria econômica tradicional ignoraram a cooperação e o conflito entre membros de uma família ao assumirem que as famílias são compostas de apenas uma pessoa, a qual maximiza sua função utilidade, sujeita a uma restrição orçamentária. Esse autor, então, inclui a influência da família na 
discussão sobre capital humano, a qual também é responsável pelo desenvolvimento do conhecimento, valores e hábitos de suas crianças.

Em sua análise sobre a mobilidade intergeracional da renda, Becker \& Tomes (1979) desenvolveram um modelo que buscava entender porque os pais maximizam sua utilidade, investindo em capital humano e não-humano de seus filhos e outros membros da família. Para tanto, assumem uma função utilidade dos pais que depende não somente de seu próprio consumo, mas também do número total de crianças e de diversas características de cada criança. Nesse modelo, os autores pressupõem que os pais estão preocupados em cuidar dos interesses relacionados a seu próprio consumo, bem como dos interesses envolvendo as características totais de todas as suas crianças. Supõem, ainda, que os pais preocupam-se com a qualidade de vida e o sucesso econômico futuro de suas crianças e a utilidade dos pais depende da riqueza agregada de

sua criança. É possível dizer, então, que os pais podem alterar o padrão de riqueza de seus filhos, investindo em fatores que irão alterar seu acúmulo de capital humano e nãohumano. Para isso, os pais precisam renunciar seu consumo individual no presente. Ou seja, ao investir na qualidade da criança, a família compara os custos diretos e os custos de oportunidade com o benefício esperado no futuro. Os investimentos continuarão enquanto a taxa marginal de retorno exceder os custos associados à melhoria de vida da criança.

\subsection{Aproximações empíricas do modelo Becker-Tomes}

A partir do modelo teórico descrito acima, diversos autores preocuparam-se em realizar estudos empíricos, a fim de analisar a influência das características familiares na demanda por escolaridade, ou mesmo, no nível educacional obtido pela criança ao longo de sua vida.

Dentre os estudos desenvolvidos com esse objetivo destaca-se o trabalho de Holmes (1999), que inclui os determinantes da demanda derivada por investimentos em 
escolaridade no modelo de escolha familiar. Segundo a autora, a educação proporciona uma melhoria na qualidade de vida da criança, mas resulta em custos monetários diretos e dispêndio relativo ao tempo dedicado aos estudos, os quais devem entrar na função de produção familiar. Propõe, então, que os determinantes da demanda por quantidade de escola sejam dados pela seguinte equação reduzida:

$$
\mathbf{S}^{*}=F\left(\mathbf{w}, \mathbf{p}_{\mathbf{m}}, \mathbf{p}_{\mathbf{n}}, \mathbf{v}, \mathbf{x}, \mathbf{z}\right)
$$

onde:

$\mathbf{S}^{*} \quad$ são anos completos de escolaridade alcançados por uma pessoa;

w é o vetor de salário corrente dos membros da família, podendo, também, representar o ganho esperado pela escolaridade recebida;

$\mathbf{p}_{\mathbf{m}} \quad$ é o vetor de preços dos insumos de mercado;

p é o vetor de preços dos insumos de não-mercado, como o tempo de deslocamento até a escola;

$\mathbf{v} \quad$ é a renda familiar não recebida no mercado;

$\mathbf{x}$ descreve características individuais e familiares específicas e

$\mathbf{z}$ representa as características comunitárias.

Holmes (1999) explica, ainda, que existem poucas informações sobre o nível de escolaridade final atingido pelos adultos. Por essa razão, pesquisas que se concentram em analisar os determinantes da escolaridade infantil tem a vantagem de permitir o uso de informações relativas às características familiares e comunitárias, bem como ao ambiente no qual a decisão de estudar foi tomada. Além disso, muitos países em desenvolvimento têm experimentado uma rápida expansão no sistema escolar, levando a crer que estudos sobre as oportunidades educacionais de diferentes épocas podem contribuir com a elaboração de políticas públicas relevantes. Na seqüência, a autora faz uso de um modelo próbite para analisar os fatores determinantes da demanda por escolaridade no Paquistão. 
O trabalho realizado por Handa (1996) parte de uma versão simplificada do modelo de escolha familiar, no qual os pais tomam a decisão com respeito à escolaridade dos filhos. Nesse caso, o problema familiar é maximizar:

$$
U(\mathbf{X}, \mathbf{Z})
$$

sujeito a $\quad p_{x} \mathbf{X}+w \mathbf{L}=w \mathbf{T}+\mathbf{Y}$

$\mathrm{e} \quad Z=Z(\mathbf{X}, t ; \mathbf{\Omega})$

Isto é, a utilidade da família é maximizada para todos os bens de mercado (X) e bens de não-mercado (Z), sujeita a uma restrição orçamentária (3) e a uma função de produção familiar dos bens de não-mercado (4). O tempo $(t)$ e os bens de mercado são insumos nessa função de produção, assim como o parâmetro de eficiência $(\Omega)$, que depende das habilidades e experiências dos trabalhadores da casa. Na equação da restrição orçamentária, $p_{x}$ representa os preços dos bens de mercado, T é o tempo de dedicação às atividades do lar, Y é a renda que a família deixa de ganhar, enquanto $w$ representa o salário e $\mathbf{L}$ é o consumo de lazer.

Nesse modelo, a demanda por escolaridade é considerada uma função crescente dos benefícios obtidos com a educação e uma função decrescente dos custos referentes a mesma. As características da família que aumentam os custos da escolaridade infantil provocam uma redução na demanda familiar por educação. Com essas pressuposições a autora estima a probabilidade de uma criança estar correntemente matriculada na escola na Jamaica, fazendo uso do modelo próbite.

Em uma pesquisa desenvolvida para a Turquia, Tansel (2000) define o nível de escolaridade desejada $\left(\mathbf{y}^{*}\right)$ como uma variável contínua não observada, especificada da seguinte forma:

$$
\mathbf{y}^{*}=\boldsymbol{\beta}^{\prime} \mathbf{X}+\mathbf{u}
$$


onde:

x é o vetor das variáveis explicativas individuais, familiares e locacionais;

$\boldsymbol{\beta} \quad$ é o vetor dos coeficientes a serem estimados e

u é o termo de erro, normalmente e independentemente distribuído.

Dado que os indivíduos assumem diferentes níveis de escolaridade $\mathbf{y}$ representa os valores observados de $\mathbf{y}^{*}$.

Para o autor, esses valores observados são tidos como uma variável discreta, visto que os indivíduos recebem valor zero quando não completaram nenhum ano na escola e os valores 2, 5, 8 ou 11, quando tiveram acesso a diversos níveis de escolaridade devidamente definidos na pesquisa. Por essa razão, explica ele, a hipótese de uma função linear é desapropriada e a regressão por Mínimos Quadrados Ordinários (M.Q.O.) é desaconselhada. Nesse caso, ele fez uso do modelo Tóbite para analisar os fatores determinantes dos diversos níveis de escolaridade obtida pelos estudantes da Turquia.

Além das variáveis ligadas às características individuais, familiares e comunitárias da criança, alguns autores preocuparam-se em incluir variáveis representativas da quantidade e qualidade escolar, a fim de analisar os determinantes da freqüência e do desempenho escolar, para países desenvolvidos e em desenvolvimento. A próxima seção apresenta alguns desses trabalhos, comentando as estratégias adotadas pelos autores e alguns resultados encontrados pelos mesmos.

\subsection{Pesquisas que reuniram variáveis da infra-estrutura escolar e das características familiares}

Levando em consideração a proposta desenvolvida por Becker-Tomes, Birdsall (1985) afirma que a decisão de matricular a criança na escola envolve custos diretos, como livros, uniformes e transporte, além dos custos indiretos, como a renúncia ao lazer e o tempo de dedicação aos estudos. Por essa razão, os pais realizam uma troca 
entre o consumo familiar no presente e a renda esperada da criança no futuro. A autora pressupõe, então, que a decisão da família pode ser influenciada pelas características familiares e pelos subsídios públicos, os quais foram definidos como sendo a disponibilidade e a qualidade da escola pública. Os dados utilizados nesse trabalho foram provenientes de uma amostra de 1\% do Censo Demográfico do Brasil de 1970, o qual continha 910.000 indivíduos e 176.000 famílias. Dessas informações, uma subamostra de 30\% foi retirada aleatoriamente, considerando crianças de 8 a 15 anos de idade.

Em suas conclusões a autora afirmou que a variável insumo público tem efeito estatisticamente significativo na escolaridade. Logo, aperfeiçoamentos no acesso a melhores escolas provocariam mudanças no custo de oportunidade, levando a um aumento no número de matrículas. Concluiu, ainda, que as melhorias na disponibilidade e na qualidade do ensino público beneficiariam mais a criança pobre e pertencente a famílias com mães menos instruídas. Enfim, foi sugerido que se fizessem novas pesquisas, levando em conta os custos de oportunidade de investir em escolaridade.

A influência das características escolares, bem como das características pessoais dos professores no resultado educacional do aluno foi analisada por Hanushek (1971). Ele trabalhou com micro-dados do sistema escolar da Califórnia (EUA), para o ano de 1969, usando como variável dependente o nível educacional dos estudantes. Nesse trabalho, concluiu que a experiência e o nível educacional dos professores não contribuíam com ganhos no resultado final atingido pelo aluno, durante o período escolar. Da mesma forma, diferentes professores e diferentes composições de classe não afetavam o desempenho do estudante. Sugeriu, então, a realização de maiores pesquisas na área. Kard \& Krueger (1992), afirmam que encontraram diferentes resultados, para diversos estudos realizados nessa área. Enquanto alguns encontraram pouca, ou talvez nenhuma, associação entre a qualidade das escolas e o desempenho dos estudantes, outros afirmam que existe uma relação significativamente positiva entre esse dois fatores. Em seu trabalho, esses autores mostraram que as taxas de retorno da educação aumentam, quando ocorrem melhorias na qualidade escolar. 
Marope (1996) realizou uma pesquisa em Botswana, com o objetivo de analisar a experiência do sistema escolar nesse país em desenvolvimento, bem como a importância da intervenção política na equalização dos resultados educacionais. Como fonte de dados foram utilizadas informações do Ministério da Educação e do exame nacional de matemática, para aquele país. Também foram aplicados questionários junto a professores e estudantes das escolas pesquisadas. Usando como principais variáveis as características familiares e pessoais do aluno, bem como as características da escola, foi possível concluir que políticas educacionais intervencionistas têm tido um significativo sucesso na redução das disparidades de desempenho acadêmico, em Botswana. Marope (1996), sugeriu, então, a distribuição cuidadosa dos recursos escolares, a fim de conduzir o país à obtenção de um sistema escolar mais igualitário.

Behrman et al. (1997) preocupou-se em analisar os determinantes da capacidade cognitiva em estudantes do ensino primário e ensino médio do Paquistão Rural. Para tanto usou informações do Ministério da Agricultura do Paquistão e fez uma pesquisa de dados primários, através de entrevistas, junto aos alunos e suas respectivas famílias. Além dessas entrevistas, foram realizados testes de leitura e matemática para captar a capacidade cognitiva dos estudantes. As principais variáveis utilizadas foram os resultados obtidos nos testes de matemática e leitura, o nível de escolaridade final atingido pelos alunos, uma matriz das características qualitativas dos professores, uma matriz das características físicas da escola e uma matriz das características familiares. Os resultados obtidos sugeriram que a razão professor-aluno, bem como a escolaridade obtida pelos professores e o impacto da sua qualidade, eram variáveis relativamente robustas, para determinar a capacidade cognitiva do aluno. Em suas conclusões, os autores afirmaram que uma infra-estrutura mínima, com bibliotecas, quadro-negro, facilidades sanitárias básicas e dimensão organizacional descentralizada influenciavam na escolaridade final obtida pelo aluno. Além disso, investimentos que melhorassem a qualidade profissional do professor, ofereceriam um ganho potencial de eficiência no sistema escolar rural do Paquistão. 
A relação entre insumo educacional e rendimento escolar foi analisada por Case \& Deaton (1999), em um estudo de caso para a África do Sul. Seu objetivo era analisar o impacto das melhorias qualitativas da escola sobre o resultado final obtido pelo aluno. Esses autores usaram como variável dependente o resultado educacional, medido em anos de escolaridade completada. As variáveis explicativas foram a razão professor-aluno, a idade, nível de urbanização, dados referentes a gênero e raça do aluno, bem como medidas do contexto familiar (incluindo informações do chefe da família e despesa familiar per capita). Os resultados finais os levaram a concluir que as características familiares, especialmente do chefe da família, têm forte influência no nível educacional atingido pelas crianças. Além disso, afirmaram que os alunos da África do Sul fariam mais progresso no desempenho educacional se houvesse um aumento no número de professores por estudante. Isto porque, a variável mais significativa da amostra foi a razão professor-aluno.

No Brasil, os determinantes do desempenho educacional foram analisados por Barros et al. (2001), em um trabalho que procurou verificar se havia relação entre o subinvestimento em capital humano e a pobreza da família. Com este objetivo, fizeram regressões usando informações da PNAD de 1996 e da Pesquisa de Padrões de Vida (PPV) de 1996/1997. A variável dependente usada no trabalho foi o número de séries completadas pelo indivíduo. Como variáveis explicativas, utilizaram a escolaridade média dos professores e variáveis de infra-estrutura como indicador de qualidade escolar. O valor esperado do salário no mercado representou o custo de oportunidade do tempo e as variáveis familiares foram a renda domiciliar per capita, bem como a escolaridade dos pais. Além disso, foram incluídas variáveis de controle para as características individuais e geográficas.

Em suas conclusões, os autores afirmaram que os fatores relacionados com a qualidade da escola são variáveis de grande influência durante a segunda etapa do ensino fundamental, perdendo importância no ensino médio. Concluíram, também, que a escolaridade dos pais, e em particular a da mãe, são de grande relevância na determinação do desempenho escolar de jovens estudantes, sendo mais significante e 
mais importante que a renda domiciliar per capita. Sendo assim, afirmaram que essa variável leva a um mecanismo de transmissão intergeracional de pobreza, provocando a desigualdade de oportunidade educacional no Brasil.

As contribuições de Handa (2001), dizem respeito a um estudo que analisou três aspectos da demanda por escolaridade. Primeiro, ela analisou o impacto das características da escola na decisão familiar de matricular-se no ensino primário. Segundo, a autora preocupou-se com aspectos de complementaridade e substitutibilidade entre as características da escola e o contexto familiar. Finalmente, seu trabalho realizou intervenções políticas baseadas na melhoria da infra-estrutura escolar, bem como na busca por maiores níveis de escolaridade. Esta pesquisa foi realizada em Moçambique e usou dados do Inquérito Nacional aos Agregados Familiares sobre as Condições de Vida (IAF), além de informações do Ministério da Educação daquele país. Sua amostra incluiu crianças em idade escolar (7 a 11 anos) de escolas do meio rural. Os aspectos acima foram medidos via equação de demanda reduzida, para a escolaridade infantil, na forma:

$$
\mathbf{S}_{\mathrm{i}}=F\left(\mathbf{x}_{\mathrm{c}}, \mathbf{x}_{\mathrm{h}}, \mathbf{x}_{\mathrm{s}}, \mathbf{u}\right)
$$

onde:

$\mathbf{x}_{\mathbf{c}} \quad$ são as características individuais da criança,

$\mathbf{x}_{\mathbf{h}}$ são as características familiares que captam o acesso a recursos, diferenças no interesse por escolaridade e custos de oportunidade,

$\mathbf{x}_{\mathbf{s}} \quad$ é o vetor das características infra-estruturais da escola e

u é o erro aleatório com as pressuposições usuais. Para suas estimativas, a autora fez uso de um modelo próbite, onde a variável dependente, $\mathbf{S}^{5}$, referia-se às crianças correntemente matriculadas no período da pesquisa.

\footnotetext{
${ }^{5}$ Aqui a variável dependente recebe uma denominação diferente da equação (1) porque pretende
} acompanhar o raciocínio adotado por Handa (2001) 
As estimativas mostraram que o aumento no número de escolas, assim como as melhorias na infra-estrutura escolar tiveram um efeito positivo na matrícula de meninos e meninas. Essa informação foi mais significativa quando se tratou de escolas construídas próximas a localização residencial do aluno. Além disso, as características familiares foram consideradas relevantes na determinação da matrícula escolar em Moçambique Rural. Em relação a qualidade escolar, verificou-se que somente as professoras treinadas causavam impacto na amostra, especialmente sobre as meninas estudantes.

Para finalizar, a autora fez simulações utilizando variáveis das características familiares e infra-estruturais da escolar, com o objetivo de sugerir políticas que pudessem melhorar as condições de escolaridade das crianças. Essas simulações mostraram que o aumento no número de escolas construídas teria impacto positivo sobre a taxa de matrícula escolar. Além disso, observou-se que as políticas de aumento da alfabetização de adultos seriam medidas mais eficientes no aumento da taxa de matrículas do ensino primário, que melhorias na renda familiar.

A metodologia utilizada pelos autores da revisão de literatura acima descrita serviu de base para a escolha do modelo econométrico a ser utilizado no presente trabalho. 


\title{
4 MODELO ECONOMÉTRICO, MATERIAL E MÉTODOS
}

\author{
"Porque Deus é o que opera em vós, \\ tanto o querer como o efetuar.”
}

(Filipenses 2:13)

Nesta seção descreve-se o modelo econométrico utilizado nas estimativas da demanda por escolaridade e do atraso escolar, para os estados de São Paulo e Pernambuco, o qual está no item 4.1. Para alcançar os resultados que serão apresentados posteriormente, essa pesquisa fez uso de dados secundários, já coletados e divulgados por instituições ligadas ao Governo Federal, a saber, o Instituto Brasileiro de Geografia e Estatística (IBGE) e o Ministério da Educação e Desporto (MEC). Essas informações foram desagregadas por municípios e as bases de dados escolhidas para tal fim foram o Censo Demográfico, o Censo Escolar e as informações sobre os repasses do FNDE. Com o objetivo de melhor esclarecer o uso que foi feito dessas informações as seções 4.2 a 4.3 apresentam uma explicação mais detalhada de cada uma delas.

\subsection{Modelo econométrico}

Com o objetivo de modelar a freqüência à escola e o atraso escolar, adotou-se como método de estimação o modelo próbite, o qual é comumente usado quando se tem 
variável dependente qualitativa (Greene, 2003). Considerando que todas as variáveis exógenas são representadas pelo vetor $\mathbf{x}$ e os parâmetros $\beta$ refletem o impacto de mudanças em $\mathbf{x}$ na variável dependente, tem-se que:

$$
\begin{aligned}
\operatorname{Prob}(\mathbf{y}=1)=F\left(\boldsymbol{\beta}^{\prime} \mathbf{x}_{i}\right) \rightarrow & \text { probabilidade de um indivíduo com determinadas } \\
& \text { características } \mathbf{x} \text { estudar ou apresentar defasagem } \\
& \text { escolar }
\end{aligned}
$$

$$
\operatorname{Prob}(\mathbf{y}=0)=1-F\left(\boldsymbol{\beta}^{\prime} \mathbf{x}_{i}\right)
$$

A variável dependente $\mathbf{y}$ terá sua esperança representada por:

$$
E(\mathbf{y})=1 . F\left(\boldsymbol{\beta}^{\prime} \mathbf{x}_{i}\right)+0 .\left(1-F\left(\boldsymbol{\beta}^{\prime} \mathbf{x}_{i}\right)\right)=F\left(\boldsymbol{\beta}^{\prime} \mathbf{x}_{i}\right)
$$

onde F(.) é a função de distribuição da normal, expressa por:

$$
\operatorname{Prob}(\mathbf{y}=1)=F\left(\boldsymbol{\beta}^{\prime} \mathbf{x}\right)=\int_{-\infty}^{\beta^{\prime} \mathbf{x}} \phi(t) d t
$$

em que

$$
\phi(t)=(2 \pi)^{-1 / 2} \exp ^{\left(-\frac{t^{2}}{2}\right)}
$$

A estimação dos parâmetros é baseada no método de máxima verossimilhança, no qual cada observação é tratada como sendo retirada de uma distribuição de Bernoulli. Segue-se, então, que o modelo é:

$$
L=\operatorname{Prob}\left(Y_{1}=y_{1}, Y_{2}=y_{2}, \ldots, Y_{n}=y_{n}\right)=\prod_{i=1}^{n}\left[F\left(\boldsymbol{\beta}^{\prime} \mathbf{x}_{i}\right)\right]^{y_{i}}\left[1-F\left(\boldsymbol{\beta}^{\prime} \mathbf{x}_{i}\right)\right]^{1-y_{i}}
$$

ou na forma logarítmica:

$$
\ln L=\sum_{i}\left\{y_{i} \ln F\left(\boldsymbol{\beta}^{\prime} \mathbf{x}_{i}\right)+\left(1-y_{i}\right) \ln \left[1-F\left(\boldsymbol{\beta}^{\prime} \mathbf{x}_{i}\right)\right]\right\}
$$

A condição de primeira ordem para o máximo requer: 


$$
\frac{\partial \ln L}{\partial \beta}=\sum\left[\frac{y_{i} f_{i}}{F_{i}}+\left(1-y_{i}\right) \frac{-f_{i}}{\left(1-F_{i}\right)}\right] \mathbf{x}_{i}=\mathbf{0}
$$

Onde $f$ é a função densidade de probabilidade e $F$ é a função distribuição de probabilidade. Como a função da normal é não linear nos parâmetros, o modelo necessitará de um método interativo para a solução.

\subsubsection{Efeitos marginais}

O efeito marginal é definido como o impacto que uma mudança em $\mathbf{x}$ causa na probabilidade de $\mathbf{y}_{\mathbf{i}}=1$ e é dado pela seguinte forma funcional:

$$
\frac{\partial E(Y)}{\partial X}=\phi\left(\boldsymbol{\beta}^{\prime} \mathbf{x}\right) \cdot \beta
$$

observe que $\partial E\left(Y_{i}\right) / \partial X$ não é $\beta$ como na regressão linear, mas é o produto do parâmetro de interesse pela função de densidade da distribuição normal. A rigor, a expressão (13) é válida para o caso de $x$ representar uma variável contínua. Se a variável explanatória for uma binária, cujos valores são 0 ou 1, os efeitos marginais são obtidos por:

$$
\operatorname{Prob}(\mathrm{y}=1 \mid \overline{\mathbf{x}}, d=1)-\operatorname{Prob}(\mathrm{y}=1 \mid \overline{\mathbf{x}}, d=0)
$$

onde $\overline{\mathbf{x}}$ é a média de todas as outras variáveis e $d$ é a variável explanatória binária.

Este trabalho estará apresentando os efeitos marginais do modelo próbite, representado por:

$$
\mathbf{y}, \mathbf{z}=F^{l}\left(\mathbf{x}_{c}, \mathbf{x}_{f}, \mathbf{x}_{e}, \mathbf{x}_{i}, \mathbf{u}\right) \quad l=\mathbf{y}, \mathbf{z}
$$

onde:

y é a freqüência;

$\mathbf{z}$ o atraso escolar. 
Para a variável freqüência escolar (y), atribui-se valor zero a não freqüência e um a freqüência à escola. A variável dependente (z), que corresponde ao atraso escolar das crianças correntemente matriculadas no sistema, assume valor um para as crianças com defasagem escolar e valor zero para aquelas sem defasagem.

Os vetores de variáveis explicativas, utilizados nos dois modelos, foram os mesmos, sendo $\mathbf{x}_{\mathrm{c}}$, o vetor das características individuais da criança, incluindo-se aí, variáveis de controle para as diferenças étnicas e regionais. $\mathbf{x}_{\mathrm{f}}$ representa o vetor das características familiares de cada criança. Tem-se, também, o vetor das características da infra-estrutura escolar $\left(\mathbf{x}_{\mathrm{e}}\right)$, assim como o vetor das interações entre as características familiares e de infra-estrutura escolar $\left(\mathbf{x}_{\mathbf{i}}\right)$. O termo u é o erro aleatório, obedecendo as pressuposições usuais.

As bases de dados escolhidas para obter as variáveis mencionadas estão descritas a seguir.

\subsection{Censo demográfico}

O Censo Demográfico é realizado com o objetivo de fazer uma coleta sistemática de informações sobre a população brasileira e tem periodicidade mínima de 10 anos. No ano 2000 esse levantamento de informações foi feito entre $1^{\circ}$ de agosto e 30 de novembro, tendo sido utilizados dois modelos de questionários, sendo que o primeiro deles investigou características referentes a 100\% da população. O segundo questionário foi aplicado em uma amostra de 11,7\% da população e continha, além das perguntas inseridas no questionário básico, questões mais detalhadas sobre as características do domicílio e de seus moradores, além de temas referentes à religião, cor ou raça, deficiência, migração, escolaridade, fecundidade, nupcialidade, trabalho e rendimento.

Para expandir os dados coletados nos questionários da amostra utilizaram-se pesos para os domicílios pesquisados, os quais tinham como limite mínimo 1, de 
maneira que cada pessoa do domicílio representasse pelo menos ela mesma e limites máximos 25 ou 50, de acordo com a fração amostral correspondente à área de ponderação em questão.

Dentre as estratégias adotadas pelo IBGE para disseminação dos resultados referentes ao Censo Demográfico 2000 estão incluídos os arquivos de microdados para cada Unidade da Federação. As informações contidas nesses arquivos permitem a desagregação para mesorregiões, microrregiões, municípios, distritos, subdistritos e regiões metropolitanas.

Para os propósitos desse trabalho, os dados foram desagregados até o nível de municípios, lembrando que, segundo o IBGE, o município é a unidade de menor hierarquia dentro da organização político-administrativa do Brasil. As microrregiões, por sua vez, correspondem a um conjunto de municípios agrupados com base em características do quadro natural, da organização da produção e de sua integração. As mesorregiões referem-se a um conjunto de microrregiões, contíguas e contidas na mesma Unidade da Federação, agrupadas com base no quadro natural, no processo social e na rede de comunicações e de lugares.

Os microdados do Censo Demográfico para o estado de São Paulo foram divulgados com um total de 4.038.217 pessoas, enquanto as informações iniciais de Pernambuco continham 935.536 pessoas. Desse conjunto de dados foram selecionadas as crianças de 7 a 14 anos, nos dois estados, como amostra principal para a realização do trabalho.

As variáveis selecionadas a partir do Censo Demográfico foram as características pessoais e familiares da criança, bem como a renda e escolaridade média dos professores. Outras informações correspondentes à qualidade escolar foram inseridas no modelo, mediante pesquisa junto ao Ministério da Educação. 


\subsection{Censo escolar}

O Censo Escolar tem como meta disponibilizar informações e estatísticas, que contribuam para a realização de diagnósticos sobre a realidade do sistema educacional brasileiro. Para tanto, é feito, anualmente, um levantamento estatísticoeducacional junto às escolas, através de questionários dirigidos aos diretores, abrangendo os três níveis da educação básica e suas modalidades - Ensino Regular, Educação Especial e Educação de Jovens e Adultos.

No ano 2000, a coleta do Censo Escolar foi realizada no mês de abril, atingindo 266,7 mil escolas, 52,7 milhões de alunos matriculados no sistema (educação infantil, ensino fundamental e ensino médio) e 2,2 milhões de Funções Docentes. Sua efetivação exigiu a colaboração de diversos atores, visto que as Secretarias Estaduais e Municipais de Educação colaboram com o Instituto Nacional de Estudos e Pesquisas Educacionais (INEP) na decisão do instrumento e dos procedimentos de coleta, bem como na distribuição dos questionários e análise final dos dados.

A partir das informações divulgadas pelo Censo Escolar é possível elaborar análises referentes ao número de alunos matriculados no sistema, bem como às taxas de rendimento escolar e à distorção idade-série. Além disso, é possível fazer levantamentos sobre o pessoal técnico e administrativo das escolas e sobre a infra-estrutura física e os equipamentos disponíveis.

Por essa razão, as informações divulgadas por este Censo foram usadas para selecionar as variáveis referentes à proporção de escolas com bibliotecas e laboratórios de informática, além do número de alunos por turma em cada município dos dois estados considerados. Estas informações foram repetidas para cada criança dentro de cada município para a realização das análises. 


\subsection{Banco de dados do FNDE}

As principais atividades desenvolvidas pelo FNDE foram devidamente explicadas no item 2.2 desse trabalho. Por essa razão, far-se-á uma rápida explanação do uso que se pretende fazer de suas estatísticas.

As verbas correspondentes aos programas do FNDE são diretamente transferidas aos municípios e/ou escolas beneficiadas. Obtiveram-se, então, as informações referentes aos repasses do PNAE e PDDE para cada município das duas Unidades da Federação, no ano 2000. Desses repasses, calculou-se a média por aluno/ano, a fim de cruzar com os dados do Censo Demográfico. Esses dois programas foram escolhidos em função da abrangência nacional dos mesmos, que se aproxima do total de alunos matriculados no ensino fundamental. A inclusão desses dois programas foi utilizada como proxy dos principais investimentos realizados pelo governo no sistema educacional, a fim de analisar sua influência na decisão familiar por escolaridade infantil e no desempenho escolar dos estudantes. 


\section{RESULTADOS E DISCUSSÃO}

“Ainda que eu falasse as línguas dos homens e dos anjos, se não tiver amor,
sou como o bronze que soa, ou como o címbalo que retine.” (I Conríntios 13:1)

O presente capítulo apresenta os resultados relacionados à análise de regressão feita para os estados de Pernambuco e São Paulo, usando a freqüência à escola e o atraso escolar como variáveis dependentes. Os efeitos marginais do modelo próbite encontram-se na seção 5.2 e o programa de computador utilizado foi o Stata 8.0. Porém, antes das regressões é apresentada uma análise preliminar das variáveis escolhidas, observando-se a tendência na decisão de a criança freqüentar a escola, ou no seu desempenho escolar, quando ocorrem variações na renda familiar per capita, nas variáveis relacionadas às características do chefe de família, nos aspectos da infraestrutura escolar, etc.. O programa utilizado para fazer a seleção dos bancos de dados e a análise estatística dos mesmos foi o SAS for Windows V8.

\subsection{Análise preliminar dos dados}

Para fazer a análise proposta nesse trabalho foram utilizados dois bancos de dados diferentes. No primeiro, foram selecionadas todas as crianças, com idade entre 7 e 14 anos, tanto no estado de São Paulo, quanto no estado de Pernambuco. A variável 
associada à freqüência escolar foi obtida transformando a pergunta "freqüenta escola ou creche?”, que é feita durante a pesquisa do Censo Demográfico, em uma binária identificada como 1 , quando a criança respondeu "sim" e 0 , quando a criança respondeu "não". Para analisar somente os estudantes do ensino fundamental foram excluídas da amostra aquelas crianças que estavam freqüentando creche ou pré-escola. Sabe-se que as principais políticas educacionais adotadas durante a década de 1990 atingiram, principalmente, as escolas públicas do ensino fundamental. Por isso, do total de crianças estudantes foram selecionadas somente aquelas que declararam estudar em escolas públicas. Para o estado de São Paulo, as crianças incluídas na amostra somam 512.435 pessoas, enquanto em Pernambuco obteve-se um total de 142.979 indivíduos.

Para selecionar o banco de dados da variável atraso escolar foram selecionadas todas as pessoas que estavam no ensino fundamental, com até 24 anos. Desse total, foram eliminadas as pessoas que declararam estar fora da escola, a fim de concentrar a análise somente nos estudantes. Em São Paulo, essas pessoas representavam 98\% do total de estudantes e, em Pernambuco correspondiam a 95\%. Dos estudantes com idade inferior a 24 anos foram excluídos aqueles que declararam ser a pessoa de referência da família, uma vez que as características do chefe de família foram incluídas como variáveis explicativas no trabalho. Também para esse caso foram excluídos os estudantes de escolas particulares e o banco de dados do estado de São Paulo contém 569.264 indivíduos, enquanto no estado de Pernambuco ficou-se com 174.769 pessoas.

A variável atraso escolar foi obtida levando em consideração os critérios adotados pelo MEC no cálculo da taxa de distorção idade-série, a qual, conforme já foi comentado anteriormente, corresponde ao percentual de alunos, em cada série, com idade superior à recomendada. Esse critério assume que, crianças com aparente atraso escolar no momento em que se realiza a pesquisa do Censo Escolar, poderiam estar com a idade adequada no início do ano letivo, por ocasião de sua matrícula. O Censo Demográfico foi realizado tendo-se setembro de 2000 como mês de referência e não fez 
levantamentos com relação à data de nascimento da pessoa pesquisada, perguntando apenas a sua idade naquele mês. Por essa razão, crianças que estavam com 9 anos no mês de referência e declararam estar cursando a segunda série do ensino fundamental, poderiam ter 8 anos no início do ano 2000. Tal situação não poderia ser caracterizada como atraso escolar. Levando em conta esse fato, o presente trabalho adotou o seguinte critério: são reconhecidas como atrasadas na escola somente as crianças que estavam na primeira série e tinham idade superior a 8 anos, bem como as crianças que estavam na segunda série, com idade superior a 9 anos e assim por diante, finalizando com as crianças que estavam na oitava-série, com idade superior a 15 anos. A variável atraso escolar é, então, uma binária identificada como 1, se o estudante está um ou mais anos atrasado na escola e, identificada como 0 , se o estudante está cursando a série ideal para sua idade.

Outro fator a ser mencionado é que os resultados levam em conta somente os efeitos das variáveis selecionadas, sobre as duas variáveis dependentes. Porém, existem efeitos não controlados que poderiam influenciar esses resultados, dentre eles, a capacidade cognitiva da criança, o preço dos bens (como material escolar), a distância entre a escola e o domicílio, etc. Ressalta-se, portanto, que a presente pesquisa reconhece a limitação dos dados escolhidos, podendo realizar-se uma análise mais complexa, posteriormente.

Passando para a análise estatística dos dados, a Figura 1 apresenta a variação na freqüência e no atraso escolar das crianças selecionadas, segundo a faixa de idade das mesmas, nos dois estados escolhidos para a análise. Percebe-se que tanto em São Paulo, quanto em Pernambuco a variação no número de crianças que vão à escola tende a formar uma parábola com vértice para cima. Em São Paulo, 94,81\% das crianças com 7 anos estavam estudando, percentual esse que chegou a 98,02\% de meninos e meninas com 10 anos. Essa freqüência cai gradativamente a partir dos 10 anos e fica em 92,85\% daqueles que tinham 14 anos. Em Pernambuco também se alcançou um percentual máximo de crianças estudantes na idade de 10 anos (94,01\%), tendo ocorrido 86,13\% de estudantes entre os pesquisados de 7 anos e 85,42\% entre aqueles com 14 anos. 

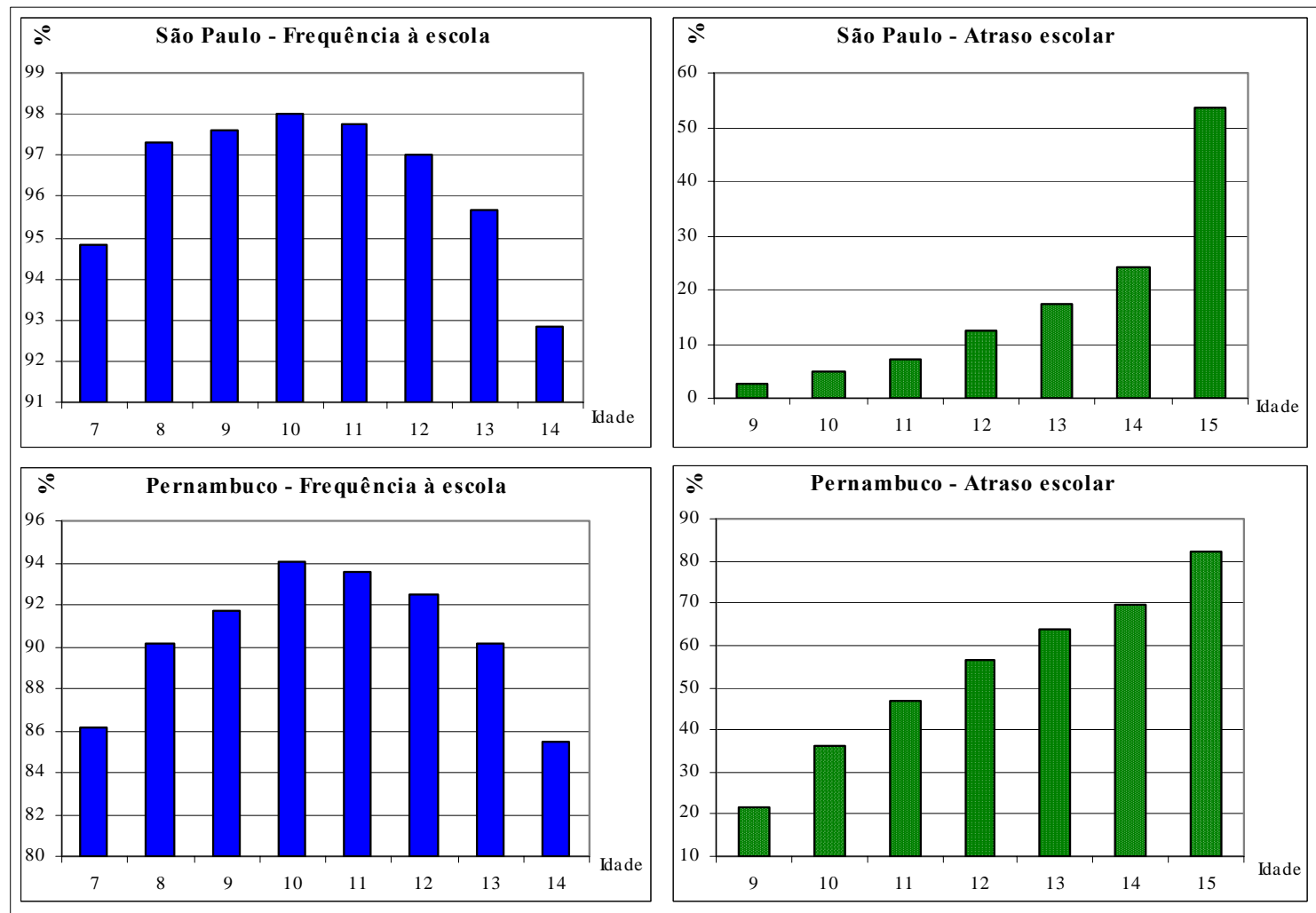

Figura 1 - Freqüência de crianças na escola e freqüência de crianças com atraso escolar, estratificada segundo a idade: São Paulo e Pernambuco - 2000

Com relação ao atraso escolar, vê-se, pela Figura 1, que não havia crianças atrasadas até a idade de 8 anos, em função do critério adotado para a seleção dessa variável. Após os 16 anos, ao contrário, todas as pessoas que cursavam o ensino fundamental estavam atrasadas em seus estudos. Entre 9 e 15 anos percebe-se que quanto maior a idade, maior o percentual de crianças cursando uma série inadequada. Os dados mostram, ainda, que o número de crianças atrasadas no estado de Pernambuco é muito maior que em São Paulo. No início, essas diferenças também aumentam com a idade, pois são de 19 pontos percentuais entre as crianças de 9 anos e chegam a 45 pontos percentuais entre aqueles de 14 anos. No entanto, entre os estudantes de 15 anos, as diferenças entre São Paulo e Pernambuco caem para 29 pontos percentuais. Destacase, ainda, o fato de haver um percentual superior a 50\% de crianças com defasagem 
escolar, entre 13 e 15 anos, no estado de Pernambuco, enquanto em São Paulo tal fato ocorre somente para as crianças de 15 anos.

Os percentuais de crianças freqüentando a escola e de crianças com atraso escolar, segundo a situação do domicílio e o sexo, podem ser vistos na Figura 2. Uma questão que já fica perceptível nessa e na análise anterior, diz respeito às diferenças nos percentuais entre os dois estados. Com relação à freqüência escolar, nota-se que em São Paulo, 96,68\% das meninas e 96,43\% dos meninos, da área urbana estavam estudando, ao passo que em Pernambuco esses percentuais eram 92,43\% e 90,33\%, respectivamente. Tendência essa, que se repete na área rural. Além disso, observa-se que a área urbana matricula mais crianças que a área rural e as meninas estudam mais que os meninos, nos dois estados analisados. A única exceção diz respeito à área rural do estado de São Paulo, onde 93,9\% das meninas estavam estudando, contra 94,31\% dos meninos.

A maior freqüência de crianças com problemas de atraso escolar também se encontra na área rural, chegando a percentuais de 24,91\% dos meninos de São Paulo e 64,59\% dos meninos de Pernambuco. Além do mais, a defasagem escolar dos meninos é superior à das meninas, nos dois estados analisados. Ferrão et al. (2002) encontrou resultados similares, utilizando dados do Saeb, em que meninos têm maiores problemas de defasagem que meninas. 


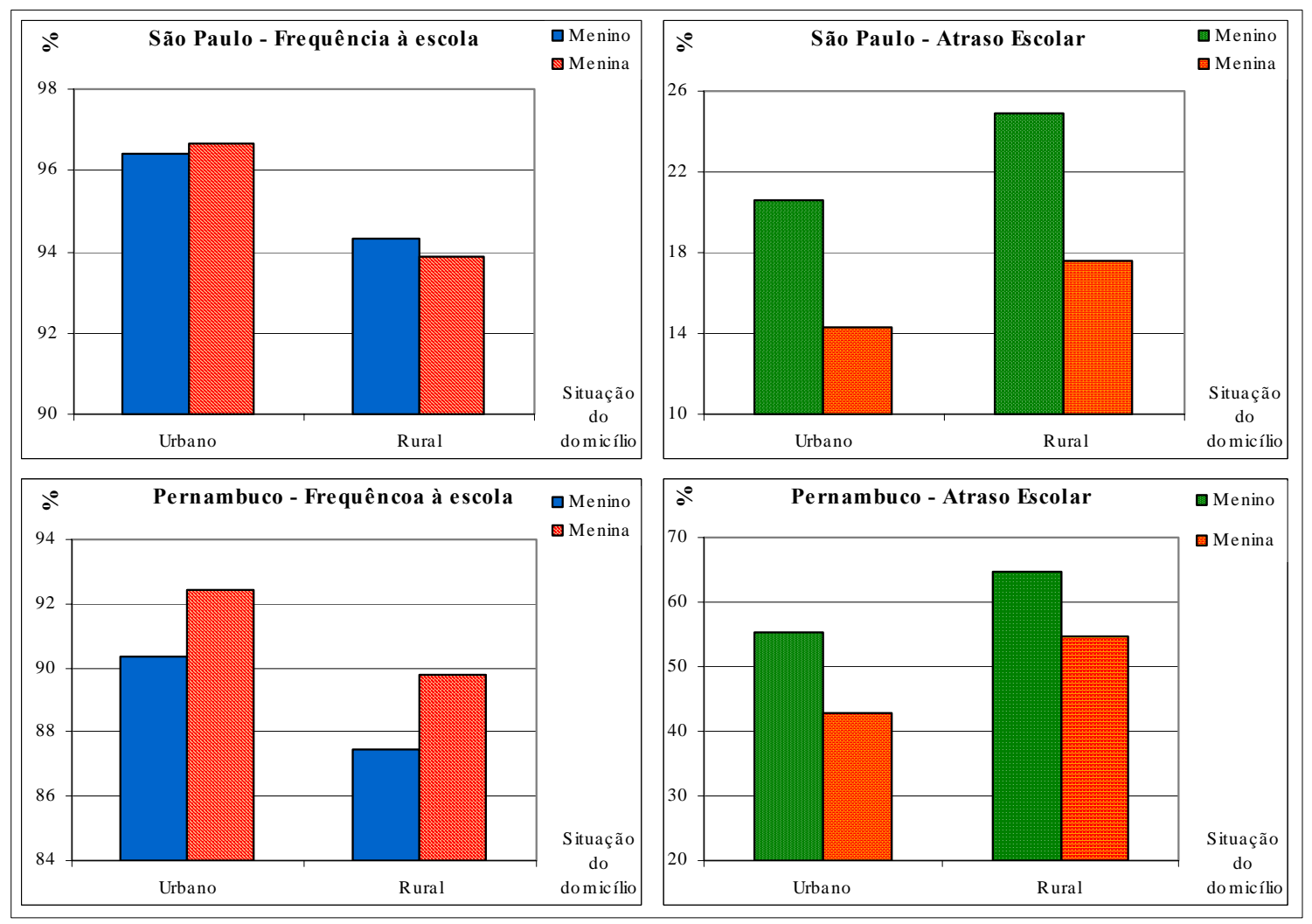

Figura 2 - Freqüência de crianças na escola e freqüência de crianças com atraso escolar, segundo o sexo e a situação do domicílio: São Paulo e Pernambuco - 2000

O Quadro 11 mostra a análise da freqüência e do atraso escolar, segundo a situação do domicílio e o sexo do chefe de família. Nos dois estados, o percentual de crianças que estão atrasadas na escola diminui quando a família é administrada por um homem. Essa alteração é mais expressiva entre as crianças da área urbana de Pernambuco, pois em famílias administradas pela mãe 54,39\% dos estudantes estavam cursando uma série inadequada para sua idade, enquanto nas famílias cujo pai era o chefe de família esse percentual cai para 46,81\%.

A presença da figura paterna à frente do lar também é importante no caso da freqüência escolar, pois essa variável apresenta melhorias quando o homem é o chefe de 
família. Cabe destacar, novamente, a área urbana de Pernambuco, cujos percentuais aumentam de $89,81 \%$ para $92,04 \%$.

\begin{tabular}{|c|c|c|c|c|c|c|c|c|}
\hline \multicolumn{9}{|c|}{ São Paulo } \\
\hline \multirow{3}{*}{$\begin{array}{l}\text { Sexo do } \\
\text { chefe de } \\
\text { família }\end{array}$} & \multicolumn{8}{|c|}{ Situação do domicílio } \\
\hline & \multicolumn{4}{|c|}{ Urbano } & \multicolumn{4}{|c|}{ Rural } \\
\hline & $\begin{array}{l}\text { Crianças } \\
\text { que } \\
\text { estudam }\end{array}$ & $\%$ & $\begin{array}{c}\text { Crianças } \\
\text { com atraso } \\
\text { escolar }\end{array}$ & $\%$ & $\begin{array}{l}\text { Crianças } \\
\text { que } \\
\text { estudam }\end{array}$ & $\%$ & $\begin{array}{c}\text { Crianças } \\
\text { com atraso } \\
\text { escolar }\end{array}$ & $\%$ \\
\hline Mulher & 868.011 & 95,61 & 240.949 & 23,04 & 41.819 & 92,30 & 14.070 & 27,18 \\
\hline Homem & 3.157 .213 & 96,82 & 575.443 & 15,99 & 325.332 & 94,35 & 78.212 & 20,67 \\
\hline \multicolumn{9}{|c|}{ Pernambuco } \\
\hline \multirow{3}{*}{$\begin{array}{l}\text { Sexo do } \\
\text { chefe de } \\
\text { família }\end{array}$} & \multicolumn{8}{|c|}{ Situação do domicílio } \\
\hline & \multicolumn{4}{|c|}{ Urbano } & \multicolumn{4}{|c|}{ Rural } \\
\hline & $\begin{array}{l}\text { Crianças } \\
\text { que } \\
\text { estudam }\end{array}$ & $\%$ & $\begin{array}{c}\text { Crianças } \\
\text { com atraso } \\
\text { escolar }\end{array}$ & $\%$ & $\begin{array}{l}\text { Crianças } \\
\text { que } \\
\text { estudam }\end{array}$ & $\%$ & $\begin{array}{c}\text { Crianças } \\
\text { com atraso } \\
\text { escolar }\end{array}$ & $\%$ \\
\hline Mulher & 198.815 & 89,81 & 154,045 & 54,39 & 40.734 & 86,79 & 36.711 & 63,80 \\
\hline Homem & 480.264 & 92,04 & 197.430 & 46,81 & 285.759 & 88,85 & 229.965 & 59,11 \\
\hline
\end{tabular}

Quadro 11 - Freqüência de crianças na escola e freqüência de crianças com atraso escolar, segundo a situação do domicílio e o sexo do chefe de família: São Paulo e Pernambuco - 2000

Fonte: IBGE (2000)

A escolaridade do chefe de família também é uma variável importante a ser mencionada. Nos dois estados a porcentagem de crianças estudando aumenta expressivamente quando o chefe tem escolaridade superior à $8^{\mathrm{a}}$ série do ensino fundamental, sendo superior a 98\% e 97\% nas zonas urbanas e rurais de São Paulo, respectivamente (Quadro 12). Em Pernambuco, quando a escolaridade do chefe corresponde às primeiras quatro séries do ensino fundamental, a freqüência escolar da criança cai em 6 pontos percentuais na área urbana e em 8 pontos percentuais na zona rural. 


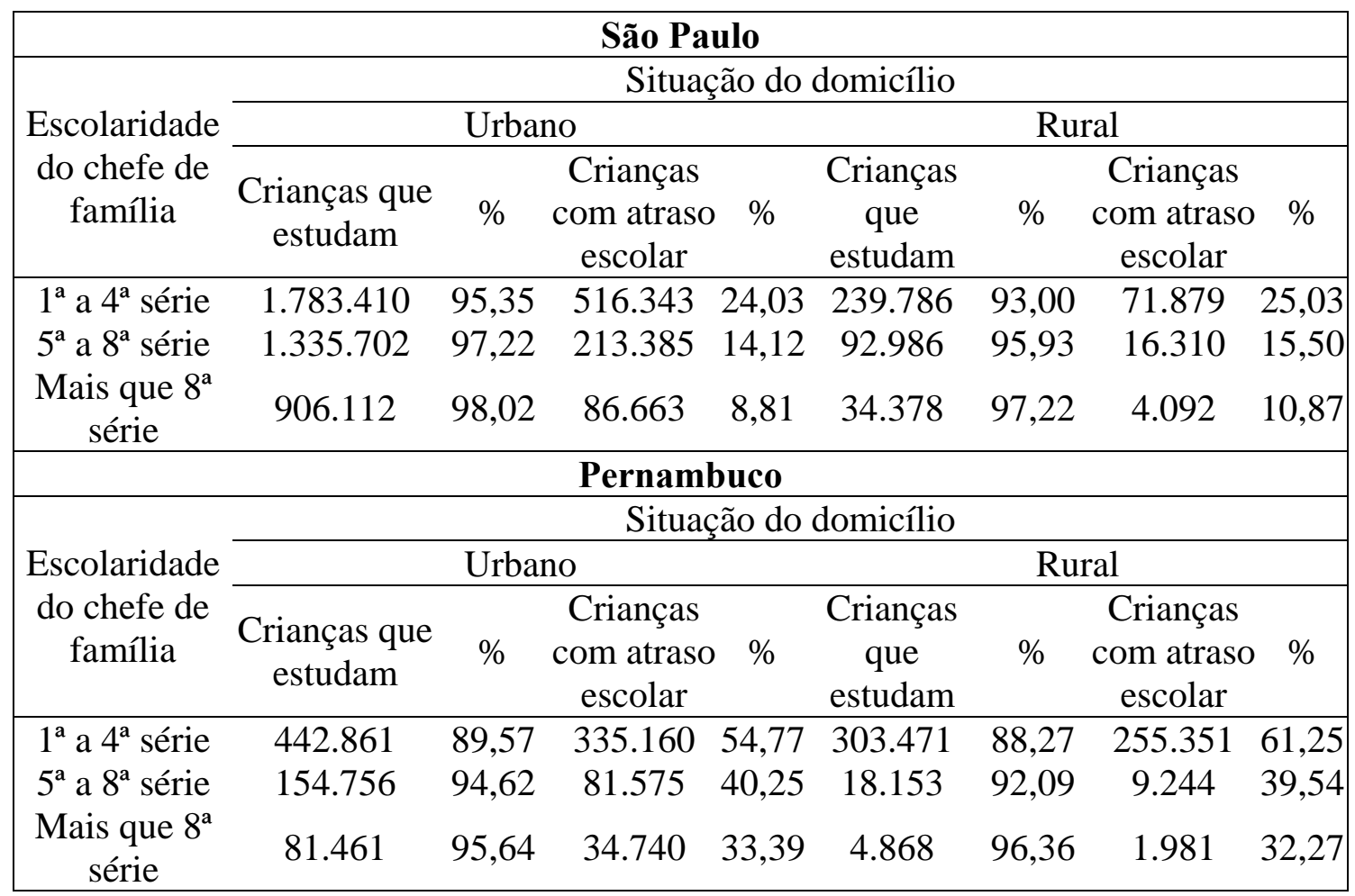

Quadro 12 - Freqüência de crianças na escola e freqüência de crianças com atraso escolar, segundo a situação do domicílio e a escolaridade do chefe de família: São Paulo e Pernambuco - 2000

Fonte: IBGE (2000)

Quando se analisa o atraso escolar dos estudantes a situação não é diferente, ocorrendo melhorias consideráveis em função da escolaridade do chefe de família. No estado de São Paulo a defasagem cai de 24\% para 8\% na área urbana e de 25\% para 10\% na área rural. Em Pernambuco as diferenças são ainda maiores, pois 54,77\% das crianças, moradoras da área urbana, cujo chefe do lar tinha a educação primária, apresentavam problemas de atraso escolar, percentual, esse, que cai para 33,39\% quando aumenta a escolaridade do chefe. Na área rural de Pernambuco existe uma diferença de 29 pontos percentuais entre os dois extremos já comentados. 
Fazendo uso da Pesquisa Mensal de Emprego (PME), no período de 1984 a 1997, Leon \& Menezes-Filho (2002) também chamaram atenção para a importância da escolaridade do chefe de família. Analisando estudantes da $4^{\mathrm{a}}$ e $8^{\mathrm{a}}$ série do ensino fundamental, assim como do $3^{\circ}$ ano do ensino médio, esses autores perceberam que a escolaridade média do chefe de família era menor entre as crianças reprovadas, quando comparadas àquelas que teriam sido aprovadas.

Em uma análise da Figura 3 é bastante perceptível a importância da renda familiar per capita, tanto no desempenho escolar, quanto no interesse da criança em estudar. No estado de São Paulo, quando a renda aumenta de até meio para até dois salários mínimos, a freqüência escolar aumenta de quase 94\% para mais de 98\% e o atraso escolar diminui de $22 \%$ para $12 \%$.
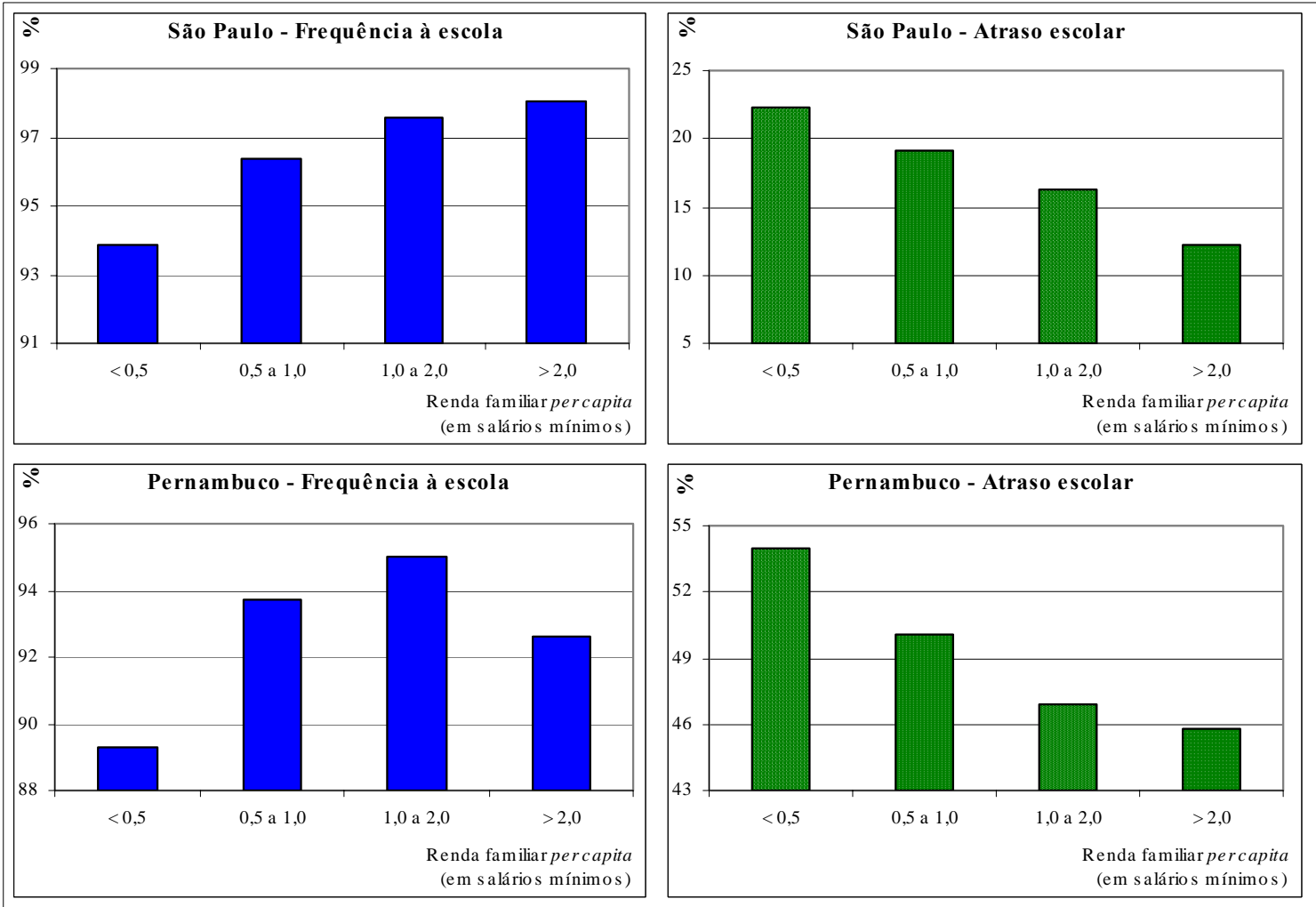

Figura 3 - Freqüência de crianças na escola e freqüência de crianças com atraso escolar, segundo a renda familiar per capita: São Paulo e Pernambuco - 2000 
A figura 3 mostra que em Pernambuco as diferenças são ainda mais nítidas, pois $89 \%$ das crianças, cujas famílias tinham renda familiar per capita inferior a meio salário mínimo eram estudantes. Esse percentual aumenta para 94\% nas famílias que tinham entre meio e um salário mínimo e 95\% nos lares em que essa variável estava entre um e dois salários mínimos. No entanto, quando a renda familiar per capita é maior que dois salários mínimos, percebe-se uma redução na freqüência de estudantes. Acredita-se que isso tenha ocorrido em função do pouco número de observações para essa faixa de renda, pois a população referia-se a 20.176 crianças, enquanto no primeiro extrato de renda a população era de 732.521 crianças.

O desempenho escolar de Pernambuco apresenta melhoria expressiva quando se aumenta a renda da família. Nota-se que 54\% das crianças pertencentes a famílias com renda per capita inferior a meio salário mínimo apresentavam defasagem escolar. Esse percentual cai para, aproximadamente, $46 \%$ nos domicílios cuja renda per capita era superior a dois salários mínimos. Nota-se, com isso, uma grande diferença no desempenho escolar das crianças pertencentes a famílias com maiores rendas, nos dois estados, pois a defasagem escolar de Pernambuco é 34 vezes maior que a de São Paulo. Vale ressaltar que, novamente, as constatações desse trabalho são similares aos resultados de Ferrão et al. (2002), que encontraram uma correlação negativa entre a defasagem idade-série e o nível socioeconômico do aluno.

Além das normas associadas aos educandos do ensino fundamental, a LDB preocupou-se em instituir o Plano de Carreira e Remuneração do Magistério, como obrigatoriedade dos estados, Distrito Federal e municípios brasileiros. Além disso, 60\% dos recursos do FUNDEF devem ser utilizados para pagamento de professores do ensino fundamental e o poder público deve preocupar-se em oferecer os recursos necessários para a formação e capacitação desses profissionais (MEC, 2004).

Em vista disso, analisa-se, agora, a influência das variáveis associadas à média de anos de estudo e ao salário do professor nas duas variáveis dependentes escolhidas. Essas variáveis também foram obtidas a partir dos dados do censo 
demográfico. Para tanto, foram identificadas as pessoas dos dois estados que declararam desempenhar a função de professor de ensino fundamental em sua principal atividade profissional. Após isso, calculou-se a média de anos de estudo e a média da renda declarada no desempenho da atividade principal, para cada município dos dois estados. Cruzaram-se, então, as informações com os dados já selecionados das crianças com idade entre 7 e 14 anos, repetindo-se a informação das variáveis correspondentes às características do professor para cada criança de um mesmo município.

No Quadro 13 pode-se ver que a variação na freqüência escolar é bem pequena, com relação a aumentos na média de anos de estudo do professor, tanto na área urbana, quanto na área rural, dos dois estados. Porém, em São Paulo, essa variação é positiva, indicando que melhorias na escolaridade do professor provocam aumentos no interesse da criança pela escola.

\begin{tabular}{|c|c|c|c|c|c|c|c|}
\hline \multicolumn{8}{|c|}{ São Paulo } \\
\hline \multirow{3}{*}{$\begin{array}{l}\text { Média de anos } \\
\text { de estudo do } \\
\text { professor }\end{array}$} & \multicolumn{7}{|c|}{ Situação do domicílio } \\
\hline & \multicolumn{4}{|c|}{ Urbano } & \multicolumn{3}{|c|}{ Rural } \\
\hline & $\begin{array}{l}\text { Crianças } \\
\text { que } \\
\text { estudam }\end{array}$ & $\%$ & $\begin{array}{l}\text { Crianças } \\
\text { com atraso } \\
\text { escolar }\end{array}$ & $\%$ & $\begin{array}{l}\text { Crianças } \\
\text { que } \\
\text { estudam }\end{array}$ & $\begin{array}{cc} & \text { Crianças } \\
\% & \text { com atraso } \\
& \text { escolar }\end{array}$ & $\%$ \\
\hline$<11$ & 21.895 & 95,90 & 4.782 & 18,66 & 160.501 & $93,65 \quad 40.219$ & 21,48 \\
\hline 11 а 13 & 951.467 & 96,44 & 200.063 & 18,16 & 152.374 & 38.736 & 21,52 \\
\hline$>13$ & 3.051 .861 & 96,60 & 611.547 & 17,39 & 54.274 & 13.326 & 21,20 \\
\hline \multicolumn{8}{|c|}{ Pernambuco } \\
\hline \multirow{3}{*}{$\begin{array}{l}\text { Média de anos } \\
\text { de estudo do } \\
\text { professor }\end{array}$} & \multicolumn{7}{|c|}{ Situação do domicílio } \\
\hline & \multicolumn{4}{|c|}{ Urbano } & \multicolumn{3}{|c|}{ Rural } \\
\hline & $\begin{array}{l}\text { Crianças } \\
\text { que } \\
\text { estudam }\end{array}$ & $\%$ & $\begin{array}{c}\text { Crianças } \\
\text { com atraso } \\
\text { escolar }\end{array}$ & $\%$ & $\begin{array}{l}\text { Crianças } \\
\text { que } \\
\text { estudam }\end{array}$ & $\begin{array}{cc} & \text { Crianças } \\
\% & \text { com atraso } \\
& \text { escolar } \\
\end{array}$ & $\%$ \\
\hline$<11$ & 27.246 & 91,19 & 18.790 & 50,88 & 243.971 & $88,29 \quad 202.219$ & 60,62 \\
\hline 11 a 13 & 607.795 & 91,57 & 405.082 & 49,22 & 78.396 & 60.926 & 56,74 \\
\hline$>13$ & 44.037 & 88,87 & 27.605 & 46,96 & 4.127 & 3.431 & 62,80 \\
\hline
\end{tabular}

Quadro 13 - Freqüência de crianças na escola e freqüência de crianças com atraso escolar, segundo a situação do domicílio e a média de anos de estudo do professor: São Paulo e Pernambuco - 2000

Fonte: IBGE (2000) 
Em Pernambuco a freqüência escolar aumenta quando a escolaridade do professor altera-se de menos onze, para uma média entre 11 e 13 anos de estudo. Quando se aumenta o nível de instrução do professor para mais de 13 anos de estudo, no entanto, a freqüência escolar diminui. Porém, o número absoluto de crianças nesse último extrato é bem reduzido, especialmente na área rural. Isso indica que a amostra relacionada é pequena e os resultados devem ser analisados com cuidado. O mesmo cuidado deve ser tomado ao observar-se os resultados de São Paulo, para as crianças cujo professor tinha escolaridade inferior ao ensino médio, em particular, na zona urbana.

Nos dois estados, aumentar a média de anos de estudo do professor propicia uma redução na porcentagem de crianças com defasagem escolar, que são moradoras da área urbana. Na área rural, no entanto, esse resultado não se verifica. Contrariamente ao esperado, um aumento na escolaridade do professor, de uma média de 11 a 13 anos de estudo, para uma média superior a 13 anos de estudo, faz aumentar o percentual de meninos e meninas com problemas de atraso escolar, em Pernambuco. Em São Paulo, as variações no atraso escolar são praticamente constantes, em função de melhorias na escolaridade do professor da zona rural. Mais uma vez, vale lembrar a importância de analisarem-se os resultados com cuidado, devido ao pequeno tamanho da amostra.

O percentual de estudantes e o número de crianças com atraso escolar, segundo a média salarial do professor, podem ser observados no Quadro 14. Verifique que os intervalos de média salarial para os professores de São Paulo são bem superiores aos intervalos de Pernambuco. Essa informação põe em evidência as diferenças socioeconômicas existentes entre os dois estados.

Em São Paulo, o percentual de estudantes da área urbana fica praticamente estável quando se passa do primeiro para o segundo intervalo da média salarial dos professores, porém ocorre uma queda nesse percentual, ao mudar-se para o terceiro intervalo. Na área rural, a freqüência de estudantes cai num primeiro instante, voltando a 
aumentar em seguida. Em Pernambuco, a porcentagem de crianças que estudam aumenta quando a média salarial dos professores, da área urbana, passa para mais de R \$ 400,00.

Ao contrário do esperado, o atraso escolar dos alunos da área urbana, do estado de São Paulo, aumenta com as melhorias na renda média do professor. Na área rural, a defasagem escolar fica praticamente estável nos três intervalos observados. Em Pernambuco, entretanto, observam-se os resultados desejados, havendo uma queda no atraso escolar dos alunos, tanto da área urbana, quanto rural, sempre que se aumenta a média salarial dos professores. Ressalta-se que, na área rural de Pernambuco não havia crianças, cujos professores recebiam uma renda superior a $\mathrm{R} \$ 400,00$.

\begin{tabular}{|c|c|c|c|c|c|c|c|c|}
\hline \multicolumn{9}{|c|}{ São Paulo } \\
\hline \multirow{3}{*}{$\begin{array}{c}\text { Média } \\
\text { salarial do } \\
\text { Professor } \\
\text { (em R\$) }\end{array}$} & \multicolumn{8}{|c|}{ Situação do domicílio } \\
\hline & \multicolumn{4}{|c|}{ Urbano } & \multicolumn{4}{|c|}{ Rural } \\
\hline & $\begin{array}{l}\text { Crianças que } \\
\text { estudam }\end{array}$ & $\%$ & $\begin{array}{c}\text { Crianças } \\
\text { com atraso } \\
\text { escolar }\end{array}$ & $\%$ & $\begin{array}{l}\text { Crianças } \\
\text { que } \\
\text { estudam }\end{array}$ & $\%$ & $\begin{array}{c}\text { Crianças } \\
\text { com atraso } \\
\text { escolar }\end{array}$ & $\%$ \\
\hline$<800$ & 1.422 .374 & 96,82 & 271.925 & 16,73 & 318.857 & 94,17 & 80.183 & 21,45 \\
\hline $800 \mathrm{a}$ & & 96,80 & 302.115 & 17,30 & 27.682 & 93,35 & 6.861 & 21,35 \\
\hline$>1$ & 1.08 & 95,87 & 242.350 & 19,06 & 20.611 & 94,12 & 5.237 & 21,64 \\
\hline \multicolumn{9}{|c|}{ Pernambuco } \\
\hline \multirow{3}{*}{$\begin{array}{c}\text { Média } \\
\text { salarial do } \\
\text { Professor } \\
\text { (em R\$) }\end{array}$} & \multicolumn{8}{|c|}{ Situação do domicílio } \\
\hline & \multicolumn{4}{|c|}{ Urbano } & \multicolumn{4}{|c|}{ Rural } \\
\hline & $\begin{array}{l}\text { Crianças que } \\
\text { estudam }\end{array}$ & $\%$ & $\begin{array}{c}\text { Crianças } \\
\text { com atraso } \\
\text { escolar }\end{array}$ & $\%$ & $\begin{array}{l}\text { Crianças } \\
\text { que } \\
\text { estudam }\end{array}$ & $\%$ & $\begin{array}{c}\text { Crianças } \\
\text { com atraso } \\
\text { escolar }\end{array}$ & $\%$ \\
\hline$<300$ & 235.588 & 91,25 & 158.136 & 49,65 & 307.835 & 88,73 & 252.721 & 59,91 \\
\hline 300 a 400 & 2 & 90,73 & 191.653 & 49,11 & 18.659 & 86,21 & 13.855 & 56,45 \\
\hline$>400$ & 153.500 & 92,83 & 101.687 & 48,43 & - & - & - & - \\
\hline
\end{tabular}

Quadro 14 - Freqüência de crianças na escola e freqüência de crianças com atraso escolar, segundo a situação do domicílio e a média salarial do professor: São Paulo e Pernambuco - 2000

Fonte: IBGE (2000) 
As variáveis referentes à proporção de escolas com laboratório de informática, proporção de escolas com biblioteca e média de alunos por turma foram obtidas com os dados do censo escolar. Para as duas primeiras variáveis, foi verificado o total de escolas existentes em cada município e o número de escolas que tinham laboratório de informática e bibliotecas, na zona urbana e rural. A proporção de escolas com tais melhorias na infra-estrutura e a média de alunos por turma, foram, então, calculadas por município e os resultados obtidos foram cruzados com o banco de dados das crianças, repetindo-se o mesmo dado dentro de cada município.

O Quadro 15 mostra as informações referentes à proporção de escolas com laboratório de informática. Note, novamente, as diferenças existentes entre os dois estados, pois em São Paulo o intervalo superior refere-se a municípios em que mais de 50\% das escolas tinham laboratório de informática. Em Pernambuco, no entanto, tem-se um intervalo superior correspondente a $10 \%$ das escolas com essa melhoria na infraestrutura.

No estado de São Paulo, quando a porcentagem de escolas com laboratório de informática aumenta de $30 \%$, para um intervalo entre $30 \%$ e $50 \%$, a freqüência de crianças na escola também aumenta, nas zonas urbana e rural. Porém, quando essa variável passa a uma proporção superior a 50\% diminui a porcentagem de estudantes. Na área urbana de Pernambuco o percentual de estudantes aumenta, sempre que ocorrem melhorias nessa variável de infra-estrutura. Enquanto isso, na área rural a porcentagem de crianças estudando apresenta uma ligeira queda.

Para a variável de atraso escolar encontrou-se resultado similar aos anteriores. Na área urbana de São Paulo o atraso das crianças cai num primeiro momento, voltando a aumentar em seguida. Na área rural, ao contrário do que se esperava, ocorre um aumento no atraso escolar, quando se aumenta a proporção de escolas com laboratório de informática. Em Pernambuco, as melhorias no desempenho escolar da criança moradora na área urbana são pouco expressivas, em função do número de escolas com laboratório de informática. Enquanto isso, na área rural, a 
defasagem escolar diminui do primeiro para o segundo intervalo considerado, porém, a amostra do segundo intervalo refere-se a uma parte muito pequena da população. Mais uma vez, chama-se a atenção para a zona rural de Pernambuco, visto que, no máximo, 10\% de suas escolas possuem laboratório de informática.

\begin{tabular}{|c|c|c|c|c|c|c|c|c|}
\hline \multicolumn{9}{|c|}{ São Paulo } \\
\hline \multirow{3}{*}{$\begin{array}{l}\text { Proporção de } \\
\text { escolas com } \\
\text { laboratório de } \\
\text { informática }\end{array}$} & \multicolumn{8}{|c|}{ Situação do domicílio } \\
\hline & \multicolumn{4}{|c|}{ Urbano } & \multicolumn{4}{|c|}{ Rural } \\
\hline & $\begin{array}{c}\text { Crianças } \\
\text { que estudam }\end{array}$ & $\%$ & $\begin{array}{c}\text { Crianças } \\
\text { com atraso } \\
\text { escolar }\end{array}$ & $\%$ & $\begin{array}{l}\text { Crianças } \\
\text { que } \\
\text { estudam }\end{array}$ & $\%$ & $\begin{array}{c}\text { Crianças } \\
\text { com atraso } \\
\text { escolar }\end{array}$ & $\%$ \\
\hline$<0,3$ & 1.712 .726 & 96,74 & 350.345 & 17,72 & 357.996 & 94,07 & 89.781 & 21,41 \\
\hline 0,3 a 0,5 & 1.130 .465 & 96,82 & 207.990 & 16,12 & 2.086 & 97,08 & 602 & 24,79 \\
\hline$>0,5$ & 1.182 .033 & 96,04 & 258.056 & 18,74 & 7.067 & 95,25 & 1.899 & 22,69 \\
\hline \multicolumn{9}{|c|}{ Pernambuco } \\
\hline \multirow{3}{*}{$\begin{array}{l}\text { Proporção de } \\
\text { escolas com } \\
\text { laboratório de } \\
\text { informática }\end{array}$} & \multicolumn{8}{|c|}{ Situação do domicílio } \\
\hline & \multicolumn{4}{|c|}{ Urbano } & \multicolumn{4}{|c|}{ Rural } \\
\hline & $\begin{array}{l}\text { Crianças } \\
\text { que estudam }\end{array}$ & $\%$ & $\begin{array}{c}\text { Crianças } \\
\text { com atraso } \\
\text { escolar }\end{array}$ & $\%$ & $\begin{array}{l}\text { Crianças } \\
\text { que } \\
\text { estudam }\end{array}$ & $\%$ & $\begin{array}{c}\text { Crianças } \\
\text { com atraso } \\
\text { escolar } \\
\end{array}$ & $\%$ \\
\hline$<0,01$ & 261.308 & 90,64 & 171.767 & 49,26 & 315.864 & 88,66 & 258.529 & 59,77 \\
\hline 0,01 a 0,10 & 224.427 & 91,10 & 149.649 & 49,05 & 10.629 & 86,34 & 8.048 & 57,89 \\
\hline$>0,10$ & 193.343 & 92,72 & 130.060 & 49,09 & - & - & - & - \\
\hline
\end{tabular}

Quadro 15 - Freqüência de crianças na escola e freqüência de crianças com atraso escolar, segundo a situação do domicílio e a proporção de escolas com laboratório de informática: São Paulo e Pernambuco - 2000

Fonte: IBGE (2000)

Quando se avalia a proporção de escolas com biblioteca, verifica-se que em Pernambuco o intervalo superior obtido corresponde a 50\% das escolas, enquanto em São Paulo tem-se mais de 75\% das escolas com biblioteca (Quadro 16). Nos dois estados, as melhorias nas condições educacionais da criança não são estáveis, quando se aumenta a proporção de escolas com biblioteca. Na área urbana de São Paulo tem-se, primeiramente, uma queda na freqüência de crianças na escola, com um posterior 
aumento. Quanto a Pernambuco, a freqüência de estudantes, na zona urbana, aumenta quando se passa do primeiro para o segundo intervalo, mas diminui quando se tem mais da metade das escolas com biblioteca.

\begin{tabular}{|c|c|c|c|c|c|c|c|c|}
\hline \multicolumn{9}{|c|}{ São Paulo } \\
\hline \multirow{3}{*}{$\begin{array}{l}\text { Proporção de } \\
\text { escolas com } \\
\text { biblioteca }\end{array}$} & \multicolumn{8}{|c|}{ Situação do domicílio } \\
\hline & \multicolumn{4}{|c|}{ Urbano } & \multicolumn{4}{|c|}{ Rural } \\
\hline & $\begin{array}{c}\text { Crianças } \\
\text { que estudam }\end{array}$ & $\%$ & $\begin{array}{l}\text { Crianças } \\
\text { com atraso } \\
\text { escolar }\end{array}$ & $\%$ & $\begin{array}{l}\text { Crianças } \\
\text { que } \\
\text { estudam }\end{array}$ & $\%$ & $\begin{array}{c}\text { Crianças } \\
\text { com } \\
\text { atraso } \\
\text { escolar }\end{array}$ & $\%$ \\
\hline$<0,65$ & 1.536 .270 & 96,61 & 321.538 & 18,04 & 345.710 & 94,04 & 87.073 & 21,50 \\
\hline 0,65 a 0,75 & 1.582.189 & 96,16 & 337.898 & 18,41 & 3.426 & 95,81 & 825 & 20,50 \\
\hline$>0,75$ & 906.764 & 97,16 & 156.955 & 15,29 & 18.013 & 95,09 & 4.383 & 20,77 \\
\hline \multicolumn{9}{|c|}{ Pernambuco } \\
\hline \multirow[b]{3}{*}{$\begin{array}{c}\text { Proporção de } \\
\text { escolas com } \\
\text { biblioteca }\end{array}$} & \multicolumn{8}{|c|}{ Situação do domicílio } \\
\hline & \multicolumn{4}{|c|}{ Urbano } & \multicolumn{4}{|c|}{ Rural } \\
\hline & $\begin{array}{c}\text { Crianças } \\
\text { que estudam }\end{array}$ & $\%$ & $\begin{array}{l}\text { Crianças } \\
\text { com atraso } \\
\text { escolar }\end{array}$ & $\%$ & $\begin{array}{l}\text { Crianças } \\
\text { que } \\
\text { estudam }\end{array}$ & $\%$ & $\begin{array}{c}\text { Crianças } \\
\text { com } \\
\text { atraso } \\
\text { escolar }\end{array}$ & $\%$ \\
\hline$<0,4$ & 265.082 & 91,17 & 176.053 & 49,59 & 325.793 & 88,59 & 265.999 & 59,73 \\
\hline 0,4 a 0,5 & 300.013 & 92,14 & 201.873 & 49,04 & - & - & - & - \\
\hline$>0,5$ & 113.983 & 89,89 & 73.550 & 48,40 & 700 & 86,27 & 578 & 54,44 \\
\hline
\end{tabular}

Quadro 16 - Freqüência de crianças na escola e freqüência de crianças com atraso escolar, segundo a situação do domicílio e a proporção de escolas com biblioteca: São Paulo e Pernambuco - 2000

Fonte: IBGE (2000)

No Quadro 16 pode-se ver que o atraso escolar de Pernambuco apresenta quedas sucessivas, sendo de 1,19 pontos percentuais quando se passa de um percentual correspondente a menos de $40 \%$ das escolas com biblioteca, para um percentual de mais de 50\%. Na área rural, porém, não é possível fazer-se uma análise consistente dos resultados, em função da inexistência, ou do baixo número de observações nos dois intervalos superiores. No estado de São Paulo a freqüência de crianças atrasadas, na área 
urbana, aumenta de 18,04\% para 18,41\%, diminuindo, em seguida, para 15,29\%, em função de aumentos na proporção de escolas com bibliotecas. Na zona rural de São Paulo os dois intervalos superiores também apresentam um baixo número de observações, indicando resultados pouco representativos da população.

O Quadro 17 apresenta as variações no atraso e na freqüência escolar, em função da média de alunos por turma dos municípios, que é uma proxy da variável razão professor-aluno utilizada na literatura. Cabe lembrar que, agora, espera-se uma relação negativa entre essa variável e o percentual de crianças que estudam, além de uma variação positiva entre a mesma e a freqüência de crianças com atraso escolar. Case \& Deaton (1999) afirmam que o aluno obtém mais progresso no sistema educacional quando há mais professores para cada estudante.

No estado de Pernambuco, quando se aumenta de menos de 30 para mais de 35 alunos por turma, em média, a freqüência escolar cai de 92\% para 90\%, na zona urbana e de 90\% para 87\% na zona rural. Quanto a São Paulo, independente da área de residência das crianças, também ocorrem reduções na porcentagem de crianças estudando, em função do aumento na média de alunos por turma.

A variável atraso escolar, do estado de Pernambuco também mostra resultados bastante expressivos. Na área urbana, quando ocorrem aumentos na média de alunos por turma, a porcentagem de crianças atrasadas aumenta de $47 \%$ para $48 \%$ e deste para 49\%. Na zona rural, por sua vez, há uma diferença de 6,08 pontos percentuais entre o primeiro e o último intervalo analisados. Quanto a São Paulo, a freqüência de crianças com defasagem escolar aumenta de $15 \%$ para $19 \%$ na zona urbana e de $21 \%$ para 24\% na área rural. No trabalho de Case \& Deaton (1999) percebeu-se, ainda, que o impacto da variável razão professor-aluno era mais forte quando se reduzia turmas muito grandes (de 40 ou 60 alunos) do que ao diminuir turmas menores (de 20 alunos). Concluíram, então, que essa variável era não linear nos parâmetros, podendo haver um limite máximo para a sua influência na variável dependente. 


\begin{tabular}{|c|c|c|c|c|c|c|c|c|}
\hline \multirow{4}{*}{$\begin{array}{l}\text { Média de } \\
\text { alunos por } \\
\text { turma }\end{array}$} & \multicolumn{7}{|c|}{ São Paulo } & \\
\hline & \multicolumn{8}{|c|}{ Situação do domicílio } \\
\hline & \multicolumn{4}{|c|}{ Urbano } & \multicolumn{4}{|c|}{ Rural } \\
\hline & $\begin{array}{l}\text { Crianças que } \\
\text { estudam }\end{array}$ & $\%$ & $\begin{array}{l}\text { Crianças } \\
\text { com atraso } \\
\text { escolar }\end{array}$ & $\%$ & $\begin{array}{l}\text { Crianças que } \\
\text { estudam }\end{array}$ & $\%$ & $\begin{array}{c}\text { Crianças } \\
\text { com atraso } \\
\text { escolar }\end{array}$ & $\%$ \\
\hline$<30$ & 160.899 & 97,18 & 27.958 & 15,32 & 305.926 & 94,41 & 76.400 & 21,31 \\
\hline 30 a 35 & 1.777 .775 & 96,99 & 325.487 & 16,08 & 47.951 & 92,54 & 12.040 & 21,47 \\
\hline$>35$ & 2.086 .570 & 96,14 & 462.947 & 19,00 & 13.273 & 92,77 & 3.841 & 24,69 \\
\hline \multicolumn{9}{|c|}{ Pernambuco } \\
\hline \multirow{3}{*}{$\begin{array}{l}\text { Média de } \\
\text { alunos por } \\
\text { turma }\end{array}$} & \multicolumn{8}{|c|}{ Situação do domicílio } \\
\hline & \multicolumn{4}{|c|}{ Urbano } & \multicolumn{4}{|c|}{ Rural } \\
\hline & $\begin{array}{l}\text { Crianças que } \\
\text { estudam }\end{array}$ & $\%$ & $\begin{array}{c}\text { Crianças } \\
\text { com atraso } \\
\text { escolar }\end{array}$ & $\%$ & $\begin{array}{c}\text { Crianças que } \\
\text { estudam }\end{array}$ & $\%$ & $\begin{array}{c}\text { Crianças } \\
\text { com atraso } \\
\text { escolar }\end{array}$ & $\%$ \\
\hline$<30$ & 31.980 & 92,40 & 20.290 & 47,93 & 58.827 & 90,15 & 44.551 & 55,22 \\
\hline 30 a 35 & 395.606 & 92,03 & 261.872 & 48,89 & 47.399 & 90,10 & 38.164 & 58,01 \\
\hline$>35$ & 251.492 & 90,24 & 169.314 & 49,69 & 220.268 & 87,86 & 183.861 & 61,30 \\
\hline
\end{tabular}

Quadro 17 - Freqüência de crianças na escola e freqüência de crianças com atraso escolar, segundo a situação do domicílio e a média de alunos por turma: São Paulo e Pernambuco - 2000

Fonte: IBGE (2000)

A cor ou raça declarada na pesquisa também foi observada, ao avaliarem-se mudanças na freqüência escolar e no percentual de crianças com atraso escolar. A figura 4 mostra que, no estado São Paulo, está entre as crianças amarelas o maior percentual de estudantes (97,01\%). Em seguida, vem as de cor branca (96,83\%). Dentre os estudantes de cor parda, 95,68\% vão para escola, enquanto esse percentual corresponde a 94,97\% dos negros. Conforme o esperado, acontece uma tendência contrária na porcentagem de crianças com atraso escolar, pois entre os brancos há 15,06\% de crianças com defasagem escolar, sendo que essa porcentagem aumenta para $27,66 \%$ entre os pretos. 

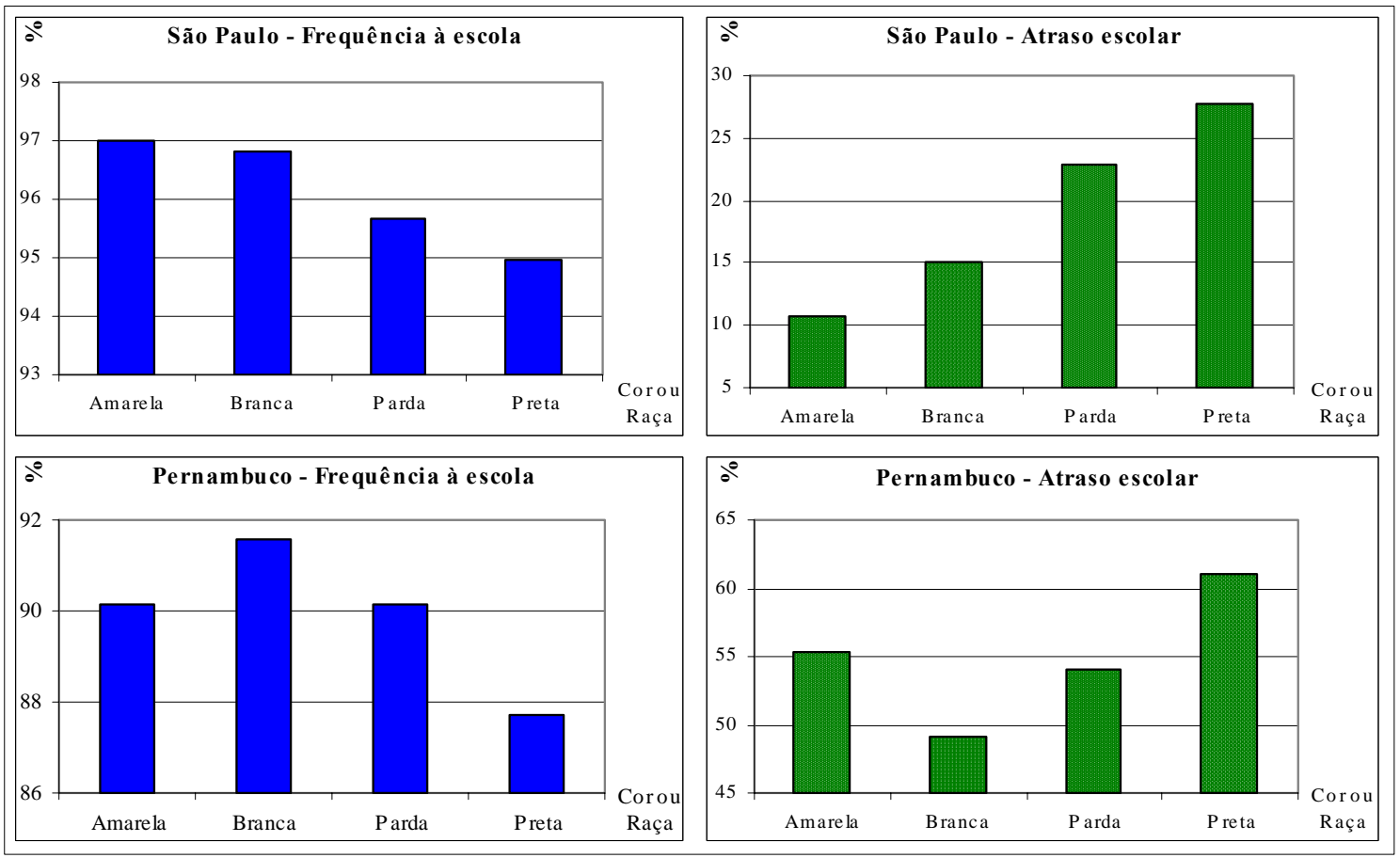

Figura 4 - Freqüência de crianças na escola e freqüência de crianças com atraso escolar, segundo a cor ou raça declarada na pesquisa: São Paulo e Pernambuco - 2000

Os resultados são um pouco diferentes para o estado de Pernambuco, aparecendo entre os brancos o maior número de crianças que freqüentam a escola (91,55\%) e o menor número de estudantes com problemas de atraso escolar (49,07\%). Nos dois casos, a diferença entre negros e brancos é bastante acentuada, pois a freqüência escolar dos pretos reduz-se para 87,73\%, correspondendo a uma queda 3,82 pontos percentuais. A defasagem escolar dos negros é muito elevada, chegando a 61,08\%, sendo que entre os pardos esse número também é expressivo (53,98\%).

As diferenças raciais observadas nesse trabalho também foram perceptíveis para Albernas et al. (2002), em uma pesquisa que foi realizada utilizando dados do exame Saeb de 1999. Ao observar o desempenho desses alunos no exame Saeb, percebeu-se que os pardos ou mulatos tinham um desempenho inferior ao dos alunos brancos em 2,5 pontos. Diferença, essa, que aumentava quando se tratava de alunos 
pretos. Para os autores a constatação das desigualdades de oportunidades é um resultado preocupante no território brasileiro. Na análise em separado das Unidades da Federação, esse trabalho também indica que o negro, além de ter menos chance de estar na escola, ao ingressar nos sistema tem um desempenho pior do que seus colegas brancos.

Para se observar a freqüência e o atraso escolar, segundo as mesorregiões de cada estado, optou-se por uma análise em separado, a fim de facilitar a visualização gráfica dos dados, sendo que os resultados de São Paulo podem ser vistos na Figura 5.

Nota-se que as mesorregiões de São Paulo com maior número de crianças na escola são Araçatuba, Presidente Prudente, Marília, Araraquara e São José do Rio Preto. Na região metropolitana de São Paulo, cuja amostra corresponde ao maior número de observações, há um percentual de $96 \%$ de crianças freqüentando a escola. Outro detalhe importante é que nas mesorregiões em que a freqüência escolar é pequena, também ocorre a maior proporção de crianças com atraso escolar. Cite-se, por exemplo, o Litoral Sul com um percentual de 94,1\% de crianças na escola e uma defasagem estudantil de 20,2\%. Tem-se, também, Itapetininga, com 17,8\% de suas crianças atrasadas e 94,03\% de freqüência escolar. Cabe destacar que na mesorregião metropolitana o atraso escolar é um dos mais elevados (19,5\%). 


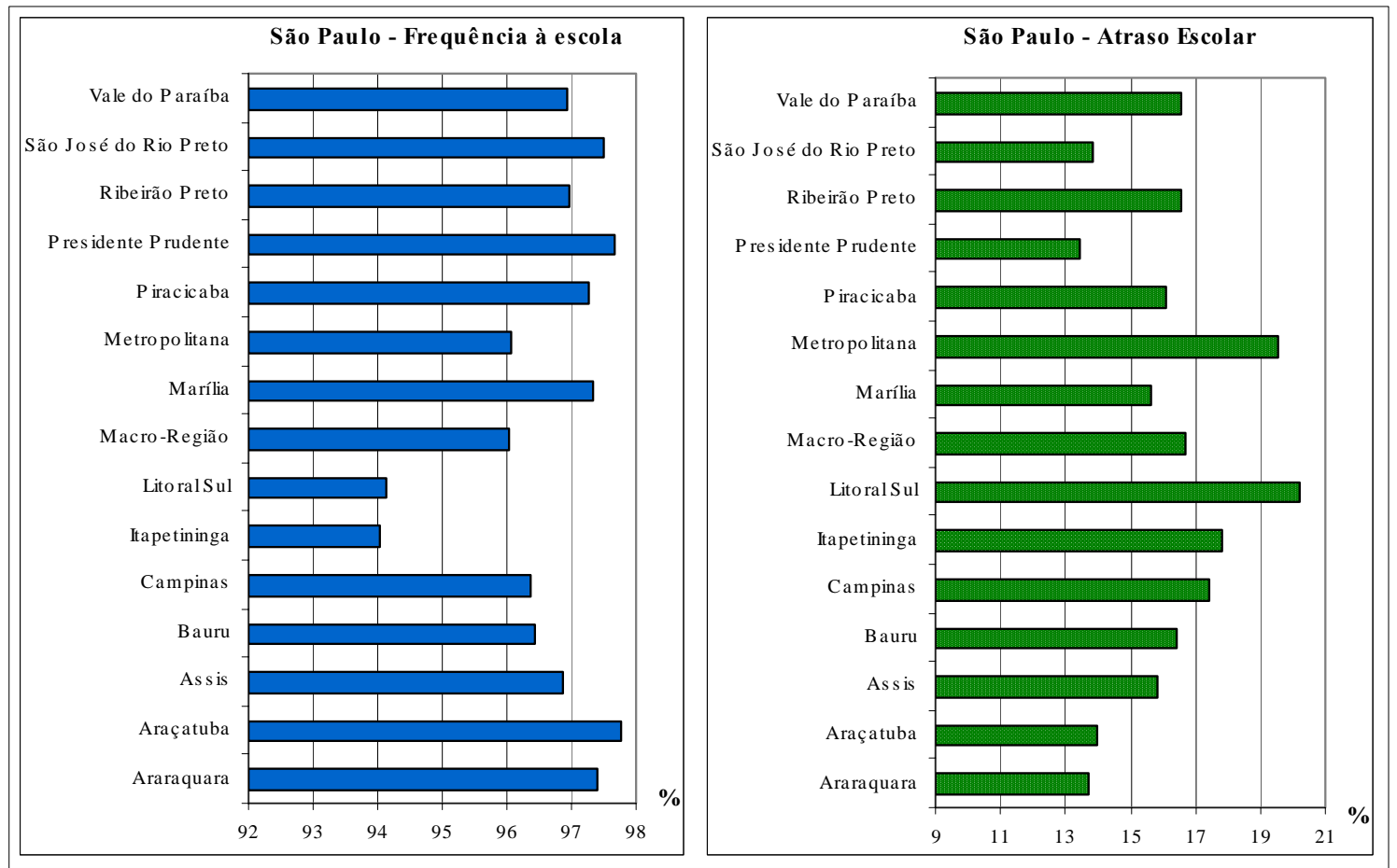

Figura 5 - Freqüência de crianças na escola e freqüência de crianças com atraso escolar, segundo as mesorregiões: São Paulo - 2000

Os resultados observados para as mesorregiões de Pernambuco são bem similares àqueles encontrados para São Paulo (Figura 6). No entanto, a mesorregião Metropolitana, que também é a mais populosa do estado, apresenta a maior porcentagem de crianças na escola (92,54\%). Em duas, das cinco mesorregiões, a freqüência escolar gira em torno de 89\%, aproximando-se de 90\% tanto na mesorregião de São Francisco, quanto no Sertão Pernambucano. Quanto ao atraso escolar tem-se um percentual de quase 49,49\% na mesorregião metropolitana e de 48,98\% no São Francisco. Nas outras três mesorregiões essa freqüência aumenta substantivamente, chegando a 56\% na Zona da Mata. 

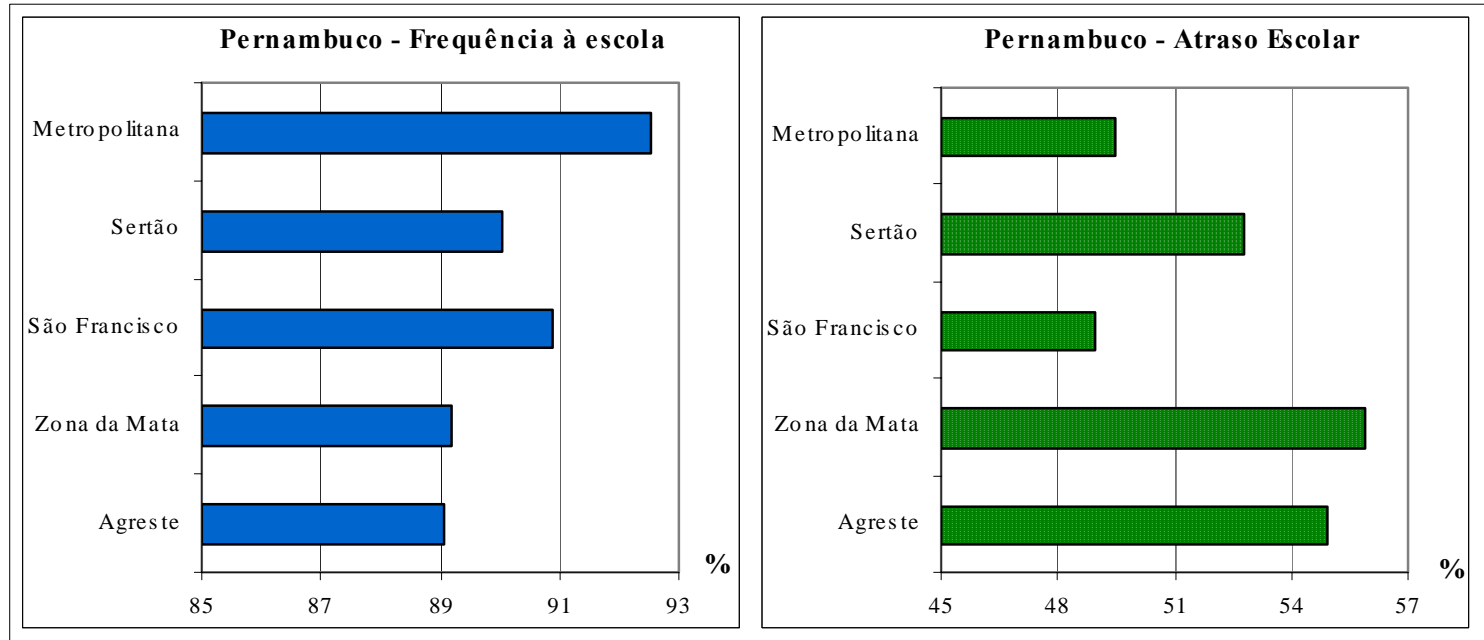

Figura 6 - Freqüência de crianças na escola e freqüência de crianças com atraso escolar, segundo as mesorregiões: Pernambuco - 2000

\subsection{Análise econométrica da freqüência e do atraso escolar}

A seguir, são apresentados os resultados econométricos das equações de freqüência e atraso escolar, para os estados de Pernambuco e São Paulo. Essas análises foram realizadas somente para a área urbana dos dois estados. O teste da máxima verossimilhança mostrou que havia diferenças significativas entre as áreas urbana e rural. Percebeu-se, então, que os resultados para a área rural não eram os esperados, apresentando estimativas não significativas para as variáveis de oferta escolar. Acreditase que esse fato tenha ocorrido devido às características peculiares do meio rural com relação à decisão de a criança estudar ou não, assim como com relação ao seu desempenho escolar. Por exemplo, uma variável não observável e importante, nesse caso, é a distância entre a residência da criança e a escola onde ela estuda. Em estudo sobre a educação brasileira no campo afirma-se que existe uma alta rotatividade de professores no meio rural, provavelmente, em função das condições de trabalho e dos salários serem inferiores àqueles obtidos na área urbana. As características físicas das escolas também são bastante precárias, no que compete à disponibilidade de laboratórios de informática, bibliotecas e outros. Além do mais, tanto professores como alunos tem 
dificuldades de acesso à escola e 69\% das crianças, moradoras da zona rural, que estudam de $5^{\mathrm{a}}$ a $8^{\mathrm{a}}$ série, são estudantes de escolas da zona urbana (Brasil, 2003). Esses e outros fatores podem ter influenciado os resultados ruins aqui obtidos para a zona rural. Em vista disso, sugere-se a realização de trabalhos que incluam variáveis capazes de captar as características acima mencionadas.

Nas análises para a área urbana foram incluídas, além das variáveis que representam as características individuais, familiares e da infra-estrutura escolar, interações da escolaridade do chefe, assim como da renda familiar per capita, com as variáveis de infra-estrutura escolar. Essas interações podem indicar substituição entre as variáveis observadas, ou podem revelar complementaridade. Se a escolaridade do chefe e a infra-estrutura escolar forem bens substitutos, aumentar a educação do chefe pode amenizar os problemas provenientes de uma baixa infra-estrutura na escola. Por outro lado, se esses bens forem complementares, crianças pertencentes a famílias com chefes bem educados são beneficiadas pela existência de uma melhor infra-estrutura escolar. Análise semelhante pode ser feita para a renda familiar per capita.

A principal base de dados utilizada foi o Censo Demográfico do ano 2000, dos dois estados, nas quais foram selecionadas as crianças de 7 a 14 anos, para analisarse a freqüência escolar e os estudantes do ensino fundamental, com idade inferior a 25 anos, para uma análise do atraso escolar. Identificaram-se, em seguida, as características individuais e familiares dessas crianças. Desse banco de dados também foram selecionadas as variáveis que identificam a média salarial e a média de anos de estudo, por município, dos professores que trabalhavam no ensino fundamental. Outras variáveis representando as características da infra-estrutura das escolas também foram selecionadas em nível de municípios, a partir das informações do Censo Escolar de 2000 e dos repasses do FNDE. Além disso, todas as regressões foram estimadas ponderandose pelo fator de expansão da amostra do censo demográfico e as médias ponderadas das variáveis utilizadas encontram-se nas Tabelas 18 e 19, abaixo. Na seção seguinte serão discutidos os resultados da freqüência escolar, ficando as discussões associadas ao atraso escolar para a próxima seção. 
Tabela 18. Média e desvio padrão das variáveis a serem utilizadas nas regressões da freqüência e atraso escolar: São Paulo

\begin{tabular}{|c|c|c|c|c|}
\hline \multirow{2}{*}{ Variáveis } & \multicolumn{2}{|c|}{$\begin{array}{l}\text { Para as regressões da } \\
\text { freqüência }\end{array}$} & \multicolumn{2}{|c|}{$\begin{array}{c}\text { Para as regressões do } \\
\text { atraso }\end{array}$} \\
\hline & Média & $\begin{array}{l}\text { Desvio } \\
\text { Padrão }\end{array}$ & Média & $\begin{array}{l}\text { Desvio } \\
\text { Padrão }\end{array}$ \\
\hline Freqüência à escola & 0,965 & 0,552 & & \\
\hline Atraso escolar & & & 0,176 & 1,154 \\
\hline Idade & 10,63 & 6,918 & 11,23 & 9,32 \\
\hline Idade ao quadrado & 118,28 & 146,60 & 135,48 & 226,94 \\
\hline Sexo $($ menino $=1)$ & 0,505 & 1,514 & 0,52 & 1,51 \\
\hline \multicolumn{5}{|l|}{ Cor ou raça } \\
\hline Branca & 0,659 & 1,435 & 0,650 & 1,445 \\
\hline Preta & 0,0399 & 0,593 & 0,0425 & 0,612 \\
\hline Amarela & 0,00442 & 0,201 & 0,00416 & 0,195 \\
\hline Parda & 0,289 & 1,371 & 0,296 & 1,383 \\
\hline \multicolumn{5}{|l|}{ Mesorregiões } \\
\hline Metropolitana & 0,516 & 1,514 & 0,523 & 1,514 \\
\hline São José do Rio Preto & 0,0350 & 0,557 & 0,0341 & 0,549 \\
\hline Ribeirão Preto & 0,0604 & 0,722 & 0,0599 & 0,719 \\
\hline Araçatuba & 0,0163 & 0,384 & 0,0161 & 0,381 \\
\hline Bauru & 0,0358 & 0,563 & 0,0350 & 0,557 \\
\hline Araraquara & 0,0196 & 0,419 & 0,0189 & 0,413 \\
\hline Piracicaba & 0,0340 & 0,549 & 0,0337 & 0,547 \\
\hline Campinas & 0,0885 & 0,860 & 0,0871 & 0,854 \\
\hline Presidente Prudente & 0,0202 & 0,427 & 0,0199 & 0,423 \\
\hline Marília & 0,0107 & 0,311 & 0,0104 & 0,308 \\
\hline Assis & 0,0141 & 0,357 & 0,0139 & 0,355 \\
\hline Itapetininga & 0,0199 & 0,424 & 0,0193 & 0,417 \\
\hline Macro-região & 0,0601 & 0,720 & 0,0595 & 0,717 \\
\hline Vale do Paraíba & 0,0579 & 0,708 & 0,0578 & 0,707 \\
\hline Litoral Sul & 0,0115 & 0,322 & 0,0113 & 0,321 \\
\hline \multicolumn{5}{|l|}{ Características da família } \\
\hline Renda familiar per capita & 208,89 & 834,03 & 208,41 & 826,23 \\
\hline Log. da renda familiar per capita & 4,76 & 4,28 & 4,78 & 4,18 \\
\hline Idade do chefe da família & 40,32 & 28,39 & 40,81 & 28,71 \\
\hline Escolaridade do chefe da família & 5,99 & 11,19 & 5,88 & 11,13 \\
\hline Sexo do chefe da família (homem = 1) & 0,78 & 1,25 & 0,77 & 1,26 \\
\hline \multicolumn{5}{|l|}{ Características da infra-estrutura escolar } \\
\hline Média de anos de estudo do professor & 13,26 & 1,48 & 13,26 & 1,48 \\
\hline Média salarial do professor & 857,34 & 475,08 & 858,21 & 474,32 \\
\hline Log. da média salarial do professor & 6,73 & 1,04 & 6,73 & 1,04 \\
\hline Proporção de escolas com biblioteca & 0,669 & 0,457 & 0,359 & 0,482 \\
\hline Prop.escolas com laboratório de informática & 0,359 & 0,481 & 0,668 & 0,457 \\
\hline Média de alunos por turma & 34,87 & 7,67 & 34,89 & 7,667 \\
\hline Repasses do PNAE (média) & 2,03 & 2,40 & 2,03 & 2,41 \\
\hline População & \multicolumn{2}{|c|}{4.168 .803} & \multicolumn{2}{|c|}{4.643 .716} \\
\hline
\end{tabular}

Fonte: resultados da pesquisa 
Tabela 19. Média e desvio padrão das variáveis a serem utilizadas nas regressões da freqüência e atraso escolar: Pernambuco

\begin{tabular}{|c|c|c|c|c|}
\hline \multirow{2}{*}{ Variáveis } & \multicolumn{2}{|c|}{$\begin{array}{c}\text { Para as regressões da } \\
\text { freqüência }\end{array}$} & \multicolumn{2}{|c|}{$\begin{array}{c}\text { Para as regressões do } \\
\text { atraso }\end{array}$} \\
\hline & Média & $\begin{array}{l}\text { Desvio } \\
\text { Padrão }\end{array}$ & Média & $\begin{array}{l}\text { Desvio } \\
\text { Padrão }\end{array}$ \\
\hline Freqüência à escola & 0,914 & 0,832 & & \\
\hline Atraso escolar & & & 0,49 & 1,49 \\
\hline Idade & 10,76 & 6,73 & 12,24 & 10,91 \\
\hline Idade ao quadrado & 120,98 & 143,30 & 163,30 & 288,79 \\
\hline $\operatorname{Sexo}($ menino $=1)$ & 0,502 & 1,483 & 0,517 & 1,486 \\
\hline \multicolumn{5}{|l|}{ Cor ou raça } \\
\hline Branca & 0,347 & 1,411 & 0,347 & 1,415 \\
\hline Preta & 0,0454 & 0,618 & 0,0461 & 0,624 \\
\hline Amarela & 0,000956 & 0,917 & 0,000988 & 0,0934 \\
\hline Parda & 0,598 & 1,454 & 0,598 & 1,458 \\
\hline \multicolumn{5}{|l|}{ Mesorregiões } \\
\hline Metropolitana & 0,448 & 1,475 & 0,462 & 1,483 \\
\hline Sertão pernambucano & 0,104 & 0,906 & 0,101 & 0,895 \\
\hline Agreste pernambucano & 0,227 & 1,242 & 0,218 & 1,228 \\
\hline Zona da Mata & 0,165 & 1,102 & 0,164 & 1,100 \\
\hline São Francisco & 0,0560 & 0,682 & 0,0548 & 0,677 \\
\hline \multicolumn{5}{|l|}{ Características da família } \\
\hline Renda familiar per capita & 75,86 & 361,76 & 82,48 & 661,65 \\
\hline Log. da renda familiar per capita & 3,60 & 4,47 & 3,73 & 4,31 \\
\hline Idade do chefe da família & 42,18 & 35,41 & 43,58 & 35,63 \\
\hline Escolaridade do chefe da família & 3,88 & 10,55 & 3,89 & 10,51 \\
\hline Sexo do chefe da família (homem = 1) & 0,70 & 1,36 & 0,69 & 1,37 \\
\hline \multicolumn{5}{|l|}{ Características da infra-estrutura escolar } \\
\hline Média de anos de estudo do professor & 12,19 & 1,81 & 12,19 & 1,81 \\
\hline Média salarial do professor & 343,03 & 243,14 & 344,14 & 245,42 \\
\hline Log. da média salarial do professor & 5,81 & 0,70 & 5,81 & 0,71 \\
\hline Prop. Escolas com laboratório de informática & 0,0666 & 0,211 & 0,0674 & 0,211 \\
\hline Média de alunos por turma & 34,54 & 19,24 & 34,55 & 19,89 \\
\hline Repasses do PNAE (média) & 1,53 & 2,19 & 1,52 & 2,19 \\
\hline Repasses do PDDE (média) & 12,13 & 9,24 & 12,09 & 9,21 \\
\hline População & \multicolumn{2}{|c|}{743.156} & \multicolumn{2}{|c|}{918.676} \\
\hline
\end{tabular}

Fonte: resultados da pesquisa 


\subsubsection{Resultados para a freqüência escolar}

Na Tabela 20 são apresentados os efeitos marginais do modelo próbite para a freqüência escolar do estado de São Paulo. A primeira coluna mostra os resultados para as variáveis escolhidas, sem incluir as interações. Na segunda coluna são incluídas as interações com a variável escolaridade do chefe e a terceira coluna mostra as interações com a variável da renda familiar per capita. Optou-se por fazer três regressões em separado porque a regressão com o total das variáveis apresentou problemas de multicolinearidade. As variáveis representativas das mesorregiões foram incluídas para controlar as diferenças culturais, de preço e outros fatores não controlados que podem existir no estado.

Na regressão 1, as estimativas dos parâmetros associados às características da criança foram altamente significativas, indicando a importância dessas variáveis na decisão de estudar da criança paulista. A variável idade da criança é positiva, enquanto a idade ao quadrado é negativa. Esses resultados estão de acordo com as estatísticas apresentadas na figura 1 e indicam que no início do ciclo estudantil a probabilidade de a criança estudar aumenta com a idade. Porém, após os dez anos, quanto maior a idade, menor a probabilidade de a criança ir para a escola.

Crianças do sexo masculino têm menor probabilidade de ir para a escola, quando comparadas a crianças do sexo feminino, provavelmente porque os meninos entram para o mercado de trabalho mais cedo, o que, muitas vezes, os obriga a optar entre o trabalho e o estudo. Com relação à cor ou raça, ser de cor preta ou parda diminui a probabilidade de freqüência escolar, quando comparado a crianças brancas. Tais resultados são similares aos encontrados por Vasconcellos (2003) e também estão de acordo com a figura 4, vindo a confirmar que as diferenças inter-raciais existentes no Brasil também podem ocorrer nos estados.

Dentre as variáveis das características familiares da criança, optou-se por trabalhar com o logaritmo da renda familiar per capita e, tanto essa quanto as outras 
variáveis foram positivas e altamente significativas. Logo, aumentar a renda familiar per capita eleva a demanda por escolaridade das crianças paulistas. Da mesma forma, quanto maior a idade e a escolaridade do chefe de família, maior a chance de a criança estudar. Nos lares em que o chefe de família é representado pela figura masculina as crianças estão mais propensas a freqüentar a escola. Em geral, mulheres responsáveis pela manutenção do lar obrigam-se a fazer jornada dupla, trabalhando em atividades remuneradas durante o dia e dispondo de tempo para dar atenção aos filhos somente em período noturno. Também é comum que nesses lares ocorra a ausência da figura paterna, o que obriga as mães a sustentarem a casa, tendo menos tempo para as crianças. Também pode ocorrer que essas mães coloquem os filhos para trabalhar, reduzindo seu tempo disponível para as crianças estudarem (tanto em casa, quanto na escola). Isso revela a importância de famílias bem estruturadas para garantir o interesse da criança pela escola.

Entre as características da infra-estrutura escolar, a média de alunos por turma apresentou o sinal esperado e foi significativa ao nível de $10 \%$. Além disso, aumentar a escolaridade do professor e o número de escolas com biblioteca eleva a probabilidade de freqüência escolar em São Paulo.

A variável que identifica a renda mensal média do professor também foi transformada em logaritmo, tendo sido significativa, mas com um sinal diferente do esperado. Acredita-se que essa variável esteja captando efeitos não controlados na amostra. Essa possibilidade já se evidenciou na análise estatística do Quadro 14, quando ocorria uma redução na freqüência à escola, a partir de um aumento na renda média do professor, de um intervalo entre $\mathrm{R} \$ 800,00$ e $\mathrm{R} \$ 1.000,00$, para um intervalo maior que R \$ 1.000,00. Professores com melhor remuneração, em geral, são mais velhos, pois sua melhoria de renda está diretamente ligada ao tempo de serviço no magistério. As dificuldades enfrentadas ao longo da carreira podem condicionar o desinteresse do professor em motivar as crianças para o ingresso e permanência na escola. Arends- 
Kuenning et al. (2004) ${ }^{6}$, ao contrário, fazendo uma análise para o Brasil, com dados da PNAD, encontraram um sinal positivo para essa variável, confirmando a hipótese de que melhorias no salário do professor podem aumentar a matrícula escolar. Nesse trabalho, foi incluída a variável tempo de serviço, que não está disponível no censo demográfico.

Elevar os repasses para o Programa Nacional de Alimentação Escolar (PNAE) também aumenta as chances de a criança freqüentar a escola. Cabe lembrar, que é comum no Brasil as afirmativas nas quais crianças pertencentes a famílias pobres freqüentam a escola em busca da "merenda escolar", visto que estão submetidas à ausência de uma refeição diária de qualidade em seus próprios lares.

Tabela 20. Efeitos marginais das regressões próbite para a freqüência à escola no ensino fundamental de escolas públicas, localizadas em área urbana, de São Paulo

\begin{tabular}{lccc}
\hline \multicolumn{1}{c}{ Variáveis } & Regressão 1 & Regressão 2 & Regressão 3 \\
\hline Idade & $0,0512^{*}$ & $0,0512^{*}$ & $0,0512^{*}$ \\
Idade ao quadrado & $-0,00253^{*}$ & $-0,00253^{*}$ & $-0,00253^{*}$ \\
Sexo (menino $=1)$ & $-0,00268^{*}$ & $-0,00268^{*}$ & $-0,00268^{*}$ \\
Cor ou raça (Branca foi omitida) & & & \\
Preta & $-0,00653^{*}$ & $-0,00651^{*}$ & $-0,00652^{*}$ \\
Amarela & $-0,00704$ & $-0,00708$ & $-0,00706$ \\
Parda & $-0,00202^{*}$ & $-0,00203^{*}$ & $-0,00201^{*}$ \\
Mesorregiões (Região metropolitana foi omitida) & & \\
São José do Rio Preto & $0,00578^{*}$ & $0,00576^{*}$ & $0,00576^{*}$ \\
Ribeirão Preto & 0,00204 & 0,00203 & 0,00202 \\
Araçatuba & $0,00806^{*}$ & $0,00807^{*}$ & $0,00811^{*}$ \\
Bauru & $-0,00148$ & $-0,00145$ & $-0,00144$ \\
Araraquara & $0,00508^{*}$ & $0,00506^{*}$ & $0,00507^{*}$ \\
Piracicaba & $0,00512^{*}$ & $0,00507^{*}$ & $0,00512^{*}$ \\
Campinas & $-0,00122$ & $-0,00123$ & $-0,00118$ \\
Presidente Prudente & $0,00911^{*}$ & $0,00911^{*}$ & $0,00918^{*}$ \\
Marília & $0,00858^{*}$ & $0,00853^{*}$ & $0,00858^{*}$ \\
Assis & $0,00439^{* *}$ & $0,00439^{*}$ & $0,00443^{* *}$ \\
Itapetininga & $-0,00939^{*}$ & $-0,00935^{*}$ & $-0,00937^{*}$ \\
\hline
\end{tabular}

${ }^{6}$ ARENDS-KUENNING, M.; KASSOUF, A. L.; FAVA, A.; ALMEIDA, A. de. The impact of school quality and school incentive programs on children's schooling and work in Brazil. 2004 (mimeog.). 
Tabela 20. Efeitos marginais das regressões próbite para a freqüência à escola no ensino fundamental de escolas públicas, localizadas em área urbana, de São Paulo

\begin{tabular}{|c|c|c|c|}
\hline Variáveis & Regressão 1 & Regressão 2 & Regressão 3 \\
\hline Macro-região & $-0,000294$ & $-0,000366$ & $-0,000303$ \\
\hline Vale do Paraíba & $0,00573 *$ & $0,00569 *$ & $0,00576 *$ \\
\hline Litoral Sul & $-0,00787 *$ & $-0,00791 *$ & $-0,00789 *$ \\
\hline \multicolumn{4}{|l|}{ Características da família } \\
\hline Log. da renda familiar per capita & $0,00548 *$ & $0,00548 *$ & 0,00570 \\
\hline Idade do chefe da família & $0,000236 *$ & $0,000237 *$ & $0,000236 *$ \\
\hline Escolaridade do chefe da família & $0,00254 *$ & $0,00726 * *$ & $0,00254 *$ \\
\hline Sexo do chefe da família (homem = 1) & $0,00507 *$ & $0,00506 *$ & $0,00505 *$ \\
\hline \multicolumn{4}{|l|}{ Características da infra-estrutura escolar } \\
\hline Média de anos de estudo do professor & $0,00258 *$ & $0,00433^{*}$ & $0,00324 * *$ \\
\hline Log. da média salarial do professor & $-0,0105^{*}$ & $-0,0104 *$ & $-0,0105^{*}$ \\
\hline Proporção de escolas com biblioteca & $0,00312 * * *$ & 0,000805 & $-0,00843^{* * *}$ \\
\hline Média de alunos por turma & $-0,000247^{* * *}$ & $-0,000255^{* * *}$ & $-0,000241^{* * *}$ \\
\hline Repasses do PNAE (média) & $0,00219 *$ & $0,00218 *$ & $0,00218 *$ \\
\hline \multicolumn{4}{|c|}{ Interações entre a infra-estrutura escolar e a escolaridade do chefe } \\
\hline $\begin{array}{l}\text { Média de anos de estudo do professor } \\
\times \text { Escolaridade do chefe da família }\end{array}$ & & $-0,000381 * *$ & \\
\hline $\begin{array}{l}\text { Proporção de escolas com } \\
\text { biblioteca } \times \text { Escolaridade do chefe da } \\
\text { família }\end{array}$ & & 0,000508 & \\
\hline \multicolumn{4}{|c|}{ Interações entre a infra-estrutura escolar e o log. da renda familiar per capita } \\
\hline Média de anos de estudo do professor $\times$ & & & $-0,000148$ \\
\hline $\begin{array}{l}\text { Proporção de escolas com biblioteca } \times \\
\text { Log. da renda familiar per capita }\end{array}$ & & & $0,00265^{*}$ \\
\hline Número de observações & 449.682 & 449.682 & 449.682 \\
\hline Teste Razão de Verossimilhança & $5.762,12 *$ & $5.775,98 *$ & $5.762,84 *$ \\
\hline
\end{tabular}

Fonte: resultados da pesquisa

*denota significância ao nível de 1\%

**denota significância ao nível de 5\%

***denota significância ao nível de 10\%

Para se fazer as interações escolheu-se as variáveis de infra-estrutura escolar que foram significativas e apresentaram um sinal de acordo com o esperado, na 
regressão 1, da tabela 20, sendo elas, a escolaridade média do professor e a proporção de escolas com biblioteca. Na coluna 2 aparecem os resultados incluindo-se as interações com a escolaridade do chefe. Somente a interação com a escolaridade média do professor foi significativa, tendo apresentado um sinal negativo, o que revela substitutibilidade entre as duas variáveis. Sendo assim, políticas públicas voltadas para melhorar o nível de instrução do professor beneficiam mais as crianças pertencentes a famílias com chefes pouco escolarizados.

As interações entre a infra-estrutura escolar e o logaritmo da renda familiar per capita podem ser visualizadas na coluna 3. Nesse caso, somente a interação com a proporção de escolas com biblioteca foi significativa, a qual apresentou um sinal positivo. No entanto, ao realizar a regressão 3 pode ter ocorrido problemas de multicolinearidade entre as variáveis da interação e a variável da proporção de escolas com biblioteca, alterando o sinal dessa segunda variável. Em vista disso, os resultados ruins não serão aqui analisados.

A inclinação obtida da interação entre a média de anos de estudo do professor e a escolaridade do chefe de família pode ser vista na figura 7, para a qual foi utilizada a seguinte equação:

Frequência $=\alpha$ esc. chefe $+\beta$ esc. professor $+\gamma$ esc. chefe $\times$ esc. professor

Portanto:

$$
\frac{\partial \text { Frequência }}{\partial \text { esc. } \text { professor }}=\beta+\gamma \text { esc. chefe }
$$

ou seja,

$$
\Delta \text { Frequência }=0,00433-0,000381 \text { esc. chefe }
$$


Pode-se observar, pela Figura 7, que o impacto de um aumento na média de anos de estudo do professor, sobre a freqüência escolar no ensino fundamental, é cada vez menor, quando se eleva a escolaridade do chefe de família.

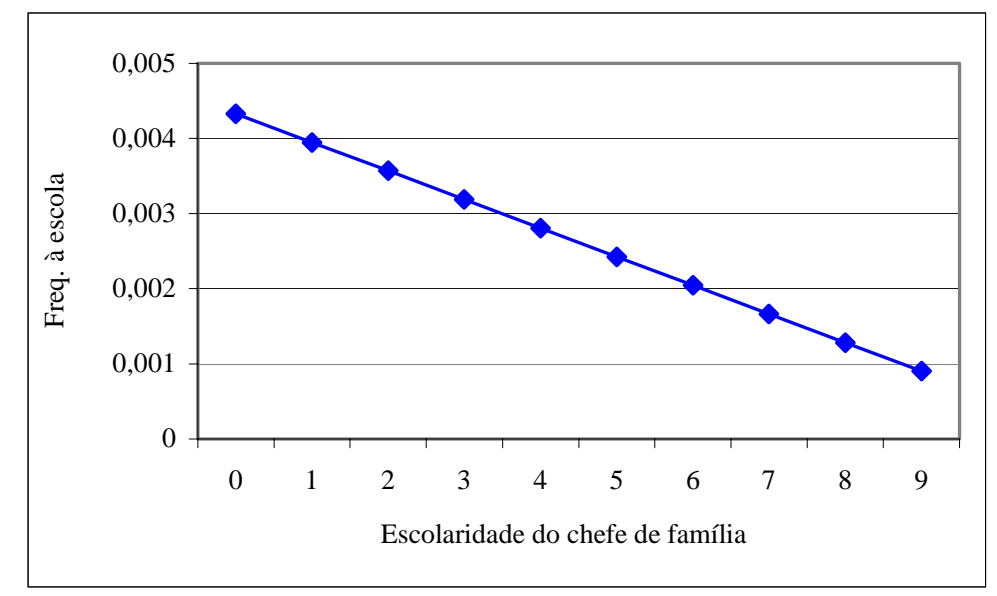

Figura 7 - Efeito da interação entre a escolaridade do chefe de família e a média de anos de estudo do professor sobre a freqüência escolar de São Paulo

Os efeitos marginais das regressões próbite para a freqüência escolar do estado de Pernambuco estão disponíveis na Tabela 21. Vê-se, na coluna 1, que as características da criança e de sua família também foram altamente significativas. Da mesma forma que no estado de São Paulo, a variável correspondente à idade da criança forma uma parábola com vértice para cima, havendo um limite para o aumento na freqüência escolar quando a criança completa 10 anos. Em Pernambuco o interesse das meninas, em freqüentar a escola, também é maior que o dos meninos. As diferenças raciais também são evidentes nesse estado, pois os brancos têm maior probabilidade de freqüentar a escola, quando comparados aos negros ou pardos, porém a variável de identificação da cor parda não foi significativa ao nível de $10 \%$.

O logaritmo da renda familiar per capita foi significativo e positivo. Logo, melhorias na renda da família elevam as chances de freqüência escolar. Chefes de família mais velhos e melhor escolarizados também estão mais aptos a incentivar a permanência na escola. Mais uma vez, a variável do sexo do chefe da família foi 
positiva, sendo um indicativo de que famílias melhor estruturadas, com a presença de um homem exercendo a função de chefe, aumentam a probabilidade de a criança freqüentar a escola. Nota-se, também, que a magnitude dos coeficientes no estado de Pernambuco é maior que no estado de São Paulo, indicando que as características familiares exercem mais efeito sobre a procura por educação das crianças pernambucanas.

Em Barros et al. (2001) os coeficientes associados à escolaridade do pai e da mãe também foram altamente significativos. Para esses autores, a magnitude desses coeficientes pode ser preocupante quando se trata de famílias pobres com pais menos escolarizados. Nesse caso, os filhos também poderiam adquirir uma educação menor e, conseqüentemente, os netos, provocando um mecanismo de transmissão intergeracional de pobreza.

Um efeito positivo e significativo para a variável renda também foi encontrado no trabalho de Vasconcellos (2003). Nesse trabalho, famílias pertencentes a quartis mais elevados de renda têm maior probabilidade de matricular seus filhos na escola. No entanto, ao observar a variação da renda e da freqüência escolar ao longo do tempo, a autora não encontrou relação direta entre essas duas variáveis. Apesar disso, os resultados indicaram que melhorias na renda podem ser importantes para o ingresso na escola de crianças pertencentes a famílias pobres.

Nas informações do FNDE pode-se perceber que as transferências do PDDE às escolas da rede pública dependem da região onde essas escolas estão atuando. O valor transferido a cada escola é determinado com base no número de alunos matriculados no ensino fundamental e o repasse de recursos privilegia as escolas do Norte, Nordeste e Centro-Oeste com montantes superiores aos das escolas do Sul e Sudeste. Vê-se, portanto, que Pernambuco pertence a uma região que, proporcionalmente, recebe uma maior parcela da verba destinada ao PDDE. Além do mais, essa verba pode ser usada para melhorias na infra-estrutura das escolas. Em vista disso, decidiu-se por incluir a média aluno/ano dos repasses do PDDE, por município, como uma variável explicativa 
da infra-estrutura escolar, para o estado de Pernambuco. Porém, na regressão 1, apesar de apresentar o sinal esperado, essa variável não foi significativa ao nível de $10 \%$ de significância, da mesma forma que a média de alunos por turma.

Ao contrário das regressões para São Paulo, a variável que identifica a proporção de escolas com laboratório de informática foi estatisticamente significativa, se comparada à proporção de escolas com biblioteca, tendo sido mantida na apresentação dos resultados finais. Essa variável foi positiva, dando um indicativo de que melhorar a infra-estrutura escolar, nos estado de Pernambuco, induz a um maior interesse das crianças pela escola.

A média de anos de estudo do professor foi significativa, mas com sinal contrário ao esperado. Observando a média das variáveis escolaridade do professor e freqüência à escola, por mesorregião, percebeu-se que em locais com professores mais bem qualificados havia uma menor proporção de crianças na escola e vice-versa. Acredita-se que essa realidade tenha influenciado no sinal do respectivo coeficiente.

O logaritmo da média salarial do professor, ao contrário do que foi visto para São Paulo, mostrou-se significativo e positivo, da mesma forma que no trabalho feito por Birdsall (1985). Em Pernambuco, aumentar o salário do professor eleva a probabilidade de freqüência escolar. Cabe lembrar que, nos dados do censo demográfico, a média salarial dos professores pernambucanos é de R \$343,03, enquanto em São Paulo essa média corresponde a R\$ 857,34. Nota-se, com isso, que aumentar o salário dos professores de Pernambuco, para patamares mais próximos da média paulista pode elevar a auto-estima desses profissionais e, consequentemente, a freqüência à escola no ensino fundamental.

Dado que as variáveis logaritmo da renda média do professor e proporção de escolas com laboratório de informática foram significativas e apresentaram o sinal esperado, as mesmas foram utilizadas nas interações com a escolaridade do chefe (regressão 2) e com o logaritmo da renda familiar per capita (regressão 3). Tanto num 
caso, quanto no outro, somente a interação com o logaritmo do salário do professor foi significativa, sendo ambas negativas.

Ou seja, o salário do professor e a escolaridade do chefe de família agem como substitutos. Em locais onde os professores estão insatisfeitos com sua remuneração pode haver pouca motivação para incentivar o ingresso das crianças na escola. Aumentar o número de anos de escolaridade para o chefe de família contribui na solução desse problema, uma vez que chefes mais educados terão mais condições de acompanhar a educação de seus filhos, mostrando-lhes em quanto o conhecimento formal poderá ser útil em sua vida adulta e profissional.

A renda familiar per capita e o salário do professor também agem como substitutos. Logo, em Pernambuco, programas de transferência de renda para as famílias pobres podem constituir-se em bons instrumentos para inserir e manter a criança na escola, principalmente em lugares onde a remuneração do professor é baixa.

Tabela 21. Efeitos marginais das regressões próbite para a freqüência à escola no ensino fundamental de escolas públicas, localizadas em área urbana, de Pernambuco

\begin{tabular}{lccc}
\hline \multicolumn{1}{c}{ Variáveis } & Regressão 1 & Regressão 2 & Regressão 3 \\
\hline Idade & $0,106^{*}$ & $0,106^{*}$ & $0,106^{*}$ \\
Idade ao quadrado & $-0,00513^{*}$ & $-0,00513^{*}$ & $-0,00513^{*}$ \\
Sexo (menino = 1) & $-0,0185^{*}$ & $-0,0185^{*}$ & $-0,0185^{*}$ \\
Cor ou raça (Branca foi omitida) & & & \\
Preta & $-0,0174^{*}$ & $-0,0172^{*}$ & $-0,017^{*}$ \\
Amarela & $-0,00652$ & $-0,00729$ & $-0,00691$ \\
Parda & $-0,00235$ & $-0,00229$ & $-0,00236$ \\
Mesorregiões (Região metropolitana foi omitida) & & \\
Sertão Pernambucano & $-0,00220$ & $-0,00230$ & $-0,00234$ \\
Agreste Pernambucano & $-0,0268^{*}$ & $-0,0268^{*}$ & $-0,0267^{*}$ \\
Zona da Mata & $-0,0166^{*}$ & $-0,0166^{*}$ & $-0,0166^{*}$ \\
São Francisco & $-0,0158^{*}$ & $-0,0163^{* *}$ & $-0,0159^{*}$ \\
Características da família & & & \\
Log. da renda familiar per capita & $0,0100^{*}$ & $0,00998^{*}$ & $0,0439^{*}$ \\
Idade do chefe da família & $0,000317^{*}$ & $0,000327^{*}$ & $0,000314^{*}$ \\
\hline
\end{tabular}


Tabela 21. Efeitos marginais das regressões próbite para a freqüência à escola no ensino fundamental de escolas públicas, localizadas em área urbana, de Pernambuco

\begin{tabular}{|c|c|c|c|}
\hline Variáveis & Regressão 1 & Regressão 2 & Regressão 3 \\
\hline Escolaridade do chefe da família & $0,00794^{*}$ & $0,0374 *$ & $0,00795 *$ \\
\hline Sexo do chefe da família (homem $=1$ ) & $0,0192 *$ & $0,0194 *$ & $0,0193 *$ \\
\hline \multicolumn{4}{|l|}{ Características da infra-estrutura escolar } \\
\hline Média de anos de estudo do professor & $-0,00897^{*}$ & $-0,00913^{*}$ & $-0,00895 *$ \\
\hline Log. da média salarial do professor & $0,0178 *$ & $0,0337 *$ & $0,0372 *$ \\
\hline $\begin{array}{l}\text { Proporção de escolas com laboratório de } \\
\text { informática }\end{array}$ & $0,0701^{*}$ & $0,0691^{*}$ & $0,0823 * *$ \\
\hline Média de alunos por turma & 0,000109 & 0,0001 & 0,000108 \\
\hline Repasses do PNAE (média) & $0,0113^{*}$ & $0,0116^{*}$ & $0,0114^{*}$ \\
\hline Repasses do PDDE (média) & 0,00418 & 0,000402 & 0,000407 \\
\hline \multicolumn{4}{|c|}{ Interações entre a infra-estrutura escolar e a escolaridade do chefe } \\
\hline $\begin{array}{l}\text { Log. da méd. salarial do professor } \times \text { Escol. } \\
\text { do chefe da família }\end{array}$ & & $-0,00505^{*}$ & \\
\hline $\begin{array}{l}\text { Proporção escolas com laboratório de } \\
\text { informática× Escol. do chefe da família }\end{array}$ & & $-0,00149$ & \\
\hline \multicolumn{4}{|c|}{ Interações entre a infra-estrutura escolar e o log. da renda familiar per capita } \\
\hline $\begin{array}{l}\text { Log. da méd. salarial do professor } \times \text { Log. } \\
\text { da renda familiar per capita }\end{array}$ & & & $-0,00579 * *$ \\
\hline $\begin{array}{l}\text { Prop. escolas com laboratório informática } \\
\times \text { Log. da renda familiar per capita }\end{array}$ & & & $-0,00346$ \\
\hline Número de observações & 73.372 & 73.372 & 73.372 \\
\hline Teste Razão de Verossimilhança & $1.573,96 *$ & $1.612,20 *$ & $1.608,01^{*}$ \\
\hline
\end{tabular}

Fonte: resultados da pesquisa

*Denota significância ao nível de 1\%

**Denota significância ao nível de 5\%

***Denota significância ao nível de $10 \%$

As relações de substitutibilidade entre o logaritmo da renda familiar per capita e a escolaridade do chefe de família, com o logaritmo da média salarial do professor, podem ser vistas na figura 8. As estratégias para obter os interceptos e as inclinações foram as mesmas das equações 22 e 23, sendo que para renda familiar per capita tem-se: 
$\Delta$ Frequência $=0,0372-0,00579 \log$ renda

e para escolaridade do chefe de família

$\Delta$ Frequência $=0,0337-0,00505$ esc. chefe

Os ganhos obtidos com o aumento na freqüência escolar, quando se eleva o salário do professor, são cada vez menores, quanto maior é a renda familiar per capita e a escolaridade do chefe de família. Além disso, a magnitude dos coeficientes que representam a inclinação é muito próxima, indicando que tanto políticas de educação de jovens e adultos, quanto políticas de transferência de renda seriam eficientes para aumentar o interesse da criança pela escola, numa situação em que o salário do professor não fosse suficientemente motivador.

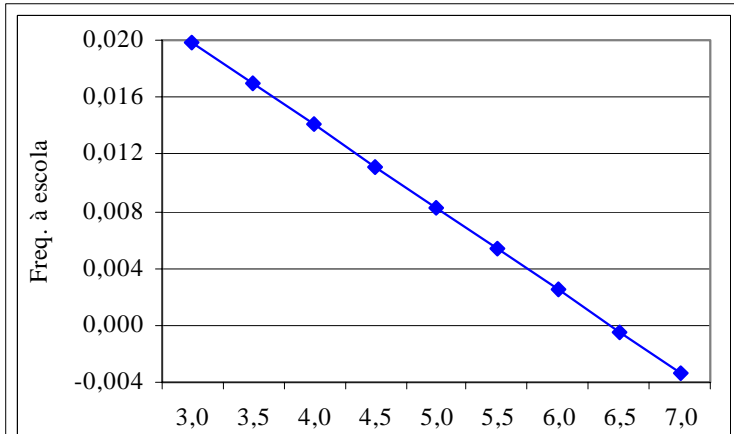

(a) Log. renda familiar per capita

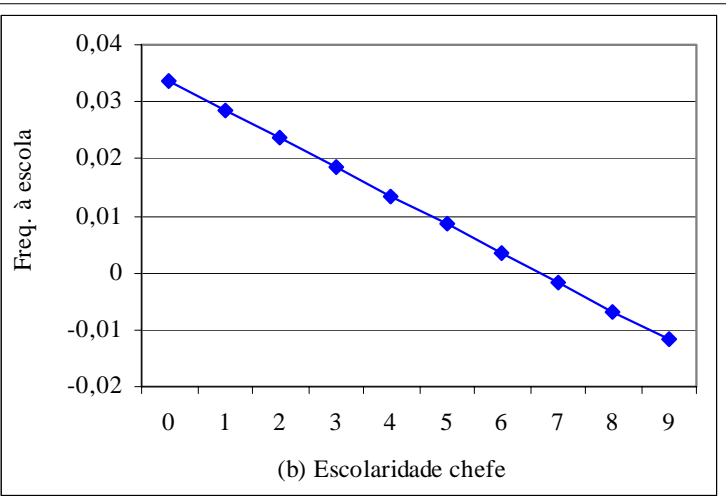

(b) Escolaridade chefe

Figura 8 - (a) Efeito da interação entre o logaritmo da renda familiar per capita e o logaritmo da média salarial do professor, sobre a freqüência escolar de Pernambuco; (b) Efeito da interação entre a escolaridade do chefe de família e o logaritmo da média salarial do professor, sobre a freqüência escolar de Pernambuco

\subsubsection{Resultados para o atraso escolar}

Nesta seção são discutidos os resultados tendo-se o atraso escolar como variável dependente. Para se fazer as regressões, utilizando o modelo próbite, criou-se 
uma variável identificada como 0 se a criança estava cursando a série ideal e identificada como 1 se a criança estava um ou mais anos atrasada, com relação a série ideal para sua idade. Nos dois estados, o modelo também foi ponderado pelo fator de expansão da amostra e as variáveis de controle das diferenças étnicas, culturais e regionais foram mantidas.

Na Tabela 22 podem-se visualizar os efeitos marginais do modelo próbite para o estado de São Paulo. Todas as variáveis das características da criança foram significativas, havendo um sinal negativo na variável da idade da criança e um sinal positivo na idade ao quadrado. Vê-se, com isso, que nos primeiros anos do ensino fundamental o atraso escolar reduz-se com a idade. No entanto, entre as crianças mais velhas, quanto maior a idade, maior a probabilidade de as mesmas atrasarem-se na escola (regressão 1). Além disso, os meninos têm maior probabilidade de atrasarem-se nos estudos, quando comparado às meninas.

As diferenças raciais voltam a confirmar-se em São Paulo, com as crianças da cor preta ou parda apresentando maiores possibilidades de defasagem escolar, se comparadas a crianças da cor branca. Esses resultados também confirmam as tendências observadas na figura 4, por ocasião da análise preliminar dos dados.

As variáveis que representam as características familiares foram todas significativas e negativas, indicando que um aumento na magnitude dessas variáveis reduz a probabilidade de a criança ficar defasada, com relação à série ideal para sua idade. Famílias com maior renda per capita têm melhores condições de procurar soluções alternativas (como aulas particulares) quando a criança demonstra dificuldades para assimilar os conhecimentos escolares. Da mesma forma, chefes de família mais escolarizados têm maior discernimento para perceber essas dificuldades e ainda podem ajudar suas crianças, tirando-lhes as dúvidas associadas às matérias da escola.

Das variáveis representativas da infra-estrutura escolar somente os repasses do PNAE foram não significativos. Entre as outras quatro, a escolaridade média do 
professor e a proporção de escolas com laboratório de informática apresentaram o sinal esperado. Capacitar melhor os professores, levando-os a adotar uma pedagogia motivadora em sala de aula, é um fator preponderante na redução do atraso escolar. Além disso, melhorar a infra-estrutura das escolas, proporcionando-lhes equipamentos adequados e modernos também pode incentivar a educação infantil, levando a uma redução da defasagem escolar de São Paulo.

Tabela 22. Efeitos marginais das regressões próbite para o atraso escolar no ensino fundamental, de escolas públicas, localizadas em área urbana, de São Paulo

\begin{tabular}{lccc}
\hline \multicolumn{1}{c}{ Variáveis } & Regressão 01 & Regressão 02 & Regressão 03 \\
\hline Idade & $-0,0859^{*}$ & $-0,0859^{*}$ & $-0,0859^{*}$ \\
Idade ao quadrado & $0,00639^{*}$ & $0,00639^{*}$ & $0,00639^{*}$ \\
Sexo (menino $=1$ ) & $0,0380^{*}$ & $0,0380^{*}$ & $0,0380^{*}$ \\
Cor ou raça (Branca foi omitida) & & & \\
Preta & $0,0466^{*}$ & $0,0466^{*}$ & $0,0466^{*}$ \\
Amarela & $-0,0219^{*}$ & $-0,0220^{* *}$ & $-0,0218^{*}$ \\
Parda & $0,0292^{*}$ & $0,0293^{*}$ & $0,0292^{*}$ \\
Mesorregiões (Região metropolitana foi omitida) & & \\
São José do Rio Preto & $-0,0192^{*}$ & $-0,0189^{*}$ & $-0,0189^{*}$ \\
Ribeirão Preto & $-0,00634^{*}$ & $-0,00616^{*}$ & $-0,00615^{*}$ \\
Araçatuba & $-0,0231^{*}$ & $-0,0230^{*}$ & $-0,0228^{*}$ \\
Bauru & $-0,00640^{*}$ & $-0,00623^{*}$ & $-0,00616^{* *}$ \\
Araraquara & $-0,0239^{*}$ & $-0,0237^{*}$ & $-0,0237^{*}$ \\
Piracicaba & $-0,00899^{*}$ & $-0,00873^{*}$ & $-0,00864^{*}$ \\
Campinas & 0,00242 & 0,00259 & 0,00264 \\
Presidente Prudente & $-0,0317^{*}$ & $-0,0314^{*}$ & $-0,0315^{*}$ \\
Marília & $-0,0102^{*}$ & $-0,00987^{* *}$ & $-0,010^{* *}$ \\
Assis & $-0,0117^{*}$ & $-0,0115^{*}$ & $-0,0114^{*}$ \\
Itapetininga & 0,00414 & 0,00415 & 0,00429 \\
Macro-região & $-0,0121^{*}$ & $-0,0119^{*}$ & $-0,0119^{*}$ \\
Vale do Paraíba & $-0,00985^{*}$ & $-0,00951^{*}$ & $-0,00973^{*}$ \\
Litoral Sul & 0,00298 & 0,00311 & 0,00309 \\
Características da família & & & \\
Log. da renda familiar per capita & $-0,0163^{*}$ & $-0,0163^{*}$ & $-0,0172^{* *}$ \\
Idade do chefe da família & $-0,000929^{*}$ & $-0,000933^{*}$ & $-0,000930^{*}$ \\
Escolaridade do chefe da família & $-0,0104^{*}$ & $-0,0158^{*}$ & $-0,0104^{*}$ \\
Sexo do chefe da família (homem $=1)$ & $-0,0181^{*}$ & $-0,0181^{*}$ & $-0,0181^{*}$ \\
\hline
\end{tabular}


Tabela 22. Efeitos marginais das regressões próbite para o atraso escolar no ensino fundamental, de escolas públicas, localizadas em área urbana, de São Paulo

\begin{tabular}{|c|c|c|c|}
\hline Variáveis & Regressão 01 & Regressão 02 & Regressão 03 \\
\hline \multicolumn{4}{|c|}{ Características da infra-estrutura escolar } \\
\hline Média de anos de estudo do professor & $-0,00197^{*}$ & $-0,00327 * *$ & $-0,00126$ \\
\hline Log. da média salarial do professor & $0,0234^{*}$ & 0,0209* & $0,0212 *$ \\
\hline $\begin{array}{l}\text { Proporção de escolas com laboratório } \\
\text { de informática }\end{array}$ & $-0,00685 * *$ & $-0,0271 *$ & $-0,0433 *$ \\
\hline Média de alunos por turma & $-0,000572 * *$ & $-0,000542 * *$ & $-0,000545 * *$ \\
\hline Repasses do PNAE (média) & 0,000136 & 0,000231 & 0,000097 \\
\hline \multicolumn{4}{|c|}{ Interações entre a infra-estrutura escolar e a escolaridade do chefe } \\
\hline $\begin{array}{l}\text { Méd. anos de estudo do } \\
\text { professor } \times \text { Esc. do chefe da família }\end{array}$ & & 0,000289 & \\
\hline $\begin{array}{l}\text { Prop. escolas com laboratório de } \\
\text { informática } \times \text { Esc. } \text { do chefe da família }\end{array}$ & & $0,00417^{*}$ & \\
\hline \multicolumn{4}{|c|}{ Interações entre a infra-estrutura escolar $e$ o log. da renda familiar per capita } \\
\hline $\begin{array}{l}\text { Méd. de anos de estudo do prof. } \\
\times \text { Log. da renda familiar per capita }\end{array}$ & & & $-0,000151$ \\
\hline $\begin{array}{l}\text { Prop. escolas laborat. de informática } \\
\times \text { Log. da renda familiar per capita }\end{array}$ & & & $0,00795^{*}$ \\
\hline Número de observações & 500.255 & 500.255 & 500.255 \\
\hline Teste Razão de Verossimilhança & $120.000 *$ & $120.000 *$ & $120.000 *$ \\
\hline
\end{tabular}

Fonte: resultados da pesquisa

*denota significância ao nível de $1 \%$

**denota significância ao nível de 5\%

***denota significância ao nível de 10\%

O coeficiente do logaritmo da renda média do professor apresentou a mesma tendência das regressões para a freqüência escolar, com um sinal contrário ao esperado. Para a média de alunos por turma esperava-se um sinal positivo, indicando que turmas muito grandes fossem nocivas ao aprendizado da criança, o que não ocorreu. Acredita-se que essa variável esteja captando características não observadas dentro da sala de aula, como as políticas ligadas ao regime de progressão continuada. Esse programa pede que os professores evitem a retenção de uma criança na mesma série, transferindo-a para séries posteriores a partir de avaliação informal realizada em classe. Em vista disso, 
mesmo que as turmas sejam numerosas e a criança não tenha absorvido a matéria completamente, a progressão ao longo do ciclo poderá ocorrer. No entanto, Bertagna (2003) comenta que os profissionais entrevistados em sua pesquisa afirmaram que o trabalho individualizado junto ao aluno é prejudicado quando as classes são muito numerosas, impossibilitando a aprendizagem efetiva da criança.

Na regressão 2, da tabela 22, podem ser vistas as interações entre a infraestrutura escolar e a escolaridade do chefe, enquanto a regressão 3 mostra as interações com o logaritmo da renda familiar per capita. Manteve-se, para o atraso escolar, o mesmo critério utilizado nas regressões para a freqüência escolar. Ou seja, foram escolhidas para representar a infra-estrutura escolar as variáveis que se apresentaram significativas, tendo um sinal de acordo com o esperado na regressão 1. Essas variáveis são a escolaridade média do professor e a proporção de escolas com laboratórios de informática.

Vale ressaltar que, agora, os sinais para os efeitos substituição e complementaridade são diferentes do que foi visto no caso da freqüência escolar. Se a interação apresentar um sinal positivo, as duas variáveis atuam como substitutas na redução do atraso escolar. Um sinal negativo indica que as duas variáveis são complementares.

Nas interações com a escolaridade do chefe, os coeficientes apresentaram um sinal positivo, revelando que existe efeito substituição entre as variáveis. No entanto, somente a interação com a proporção de escolas com laboratório de informática foi significativa. Assim, para famílias cuja escolaridade da pessoa responsável pelo lar é baixa, o aperfeiçoamento do ensino ministrado na escola, pode contribuir para a melhoria do desempenho escolar da criança.

Na regressão 3, a interação entre o logaritmo da renda familiar per capita e a proporção de escolas com laboratório de informática também foi positiva e significativa. Nesse caso, se as crianças estão inseridas em famílias nas quais a renda per capita é 
pequena, melhorar a infra-estrutura disponível na escola pode motivá-la na busca do conhecimento, melhorando, assim, seu desempenho escolar.

A Figura 9 mostra as inclinações resultantes das interações entre a infraestrutura escolar e as características familiares da criança. A título de exemplo, a equação utilizada na interação entre a proporção de escolas com laboratório de informática e o logaritmo da renda familiar per capita foi:

$$
\text { Atraso }=-\alpha \log \text { renda }-\beta \text { infra-estrutura }+\gamma \log \text { renda } \times \text { infra-estrutura }
$$

Portanto:

$$
\frac{\partial \text { Atraso }}{\partial \text { infra }- \text { estrutura }}=-\beta+\gamma \text { log renda }
$$

ou seja,

$$
\Delta \text { Atraso }=-0,0433+0,00795 \log \text { renda }
$$

Estratégia similar foi adotada para a interação com a escolaridade do chefe de família.

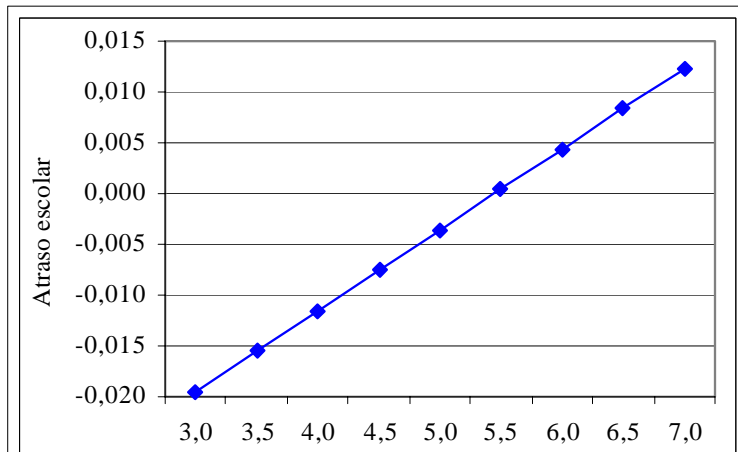

(a) Log. renda familiar per capita

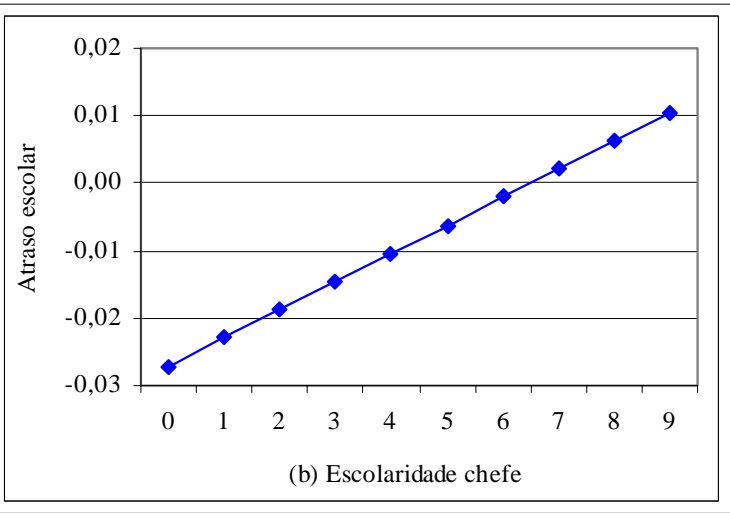

Figura 9 - (a) Efeito da interação entre o logaritmo da renda familiar per capita e a proporção de escolas com laboratório de informática, sobre o atraso escolar de São Paulo (b) Efeito da interação entre a escolaridade do chefe de família e a proporção de escolas com laboratório de informática, sobre o atraso escolar de São Paulo. 
No painel (a) da figura 9, as interações com o logaritmo da renda familiar per capita revelam que apenas em famílias relativamente pobres as melhorias na infraestrutura escolar causam redução do atraso escolar. No painel (b) pode-se observar que quanto menor a escolaridade do chefe de família, maior a redução no atraso escolar, causada por uma melhoria na infra-estrutura escolar.

Na Tabela 23 podem ser visualizados resultados das regressões próbite para o estado de Pernambuco, tendo-se o atraso escolar como variável dependente. Ao contrário de São Paulo, a variável idade tem um sinal positivo, indicando que o atraso escolar aumenta com a idade da criança. Porém, o sinal negativo da variável idade ao quadrado demonstra que a proporção do aumento no atraso escolar, de uma idade para outra, é cada vez menor, quando o estudante do ensino fundamental avança para idades maiores.

O sinal positivo da variável sexo é indicativo de que os meninos atrasam-se mais na escola que as meninas. Além disso, a magnitude desse coeficiente confirma as evidências já verificadas na Figura 2, de que a diferença no desempenho escolar, entre meninos e meninas é mais evidente em Pernambuco. Essa constatação pode estar relacionada ao trabalho precoce desenvolvido mais por meninos, do que por meninas, na região Nordeste.

Ser preto ou pardo (com relação a branco), ou morar nas mesorregiões do sertão e agreste pernambucano, bem como na zona da mata (com relação a morar na mesorregião metropolitana) também aumenta a probabilidade de atraso escolar.

Aqui, as variáveis representativas das características familiares também foram altamente significativas e todas apresentaram o sinal esperado, evidenciando a importância de uma melhoria na qualidade de vida das famílias pernambucanas, a fim de melhorar o desempenho escolar de suas crianças. O efeito positivo da educação dos pais sobre o aumento da escolaridade do indivíduo também foi comentado por Holmes (1999) em seu estudo para o Paquistão. Além disso, naquele país, aumentar o poder aquisitivo da família também melhora as condições educacionais da população. 
Vasconcellos (2003) confirma a tendência das variáveis associadas às características familiares para o Brasil. Em seu estudo, crianças pertencentes ao quartil superior da renda tem melhores chances de estar na série ideal do que crianças inseridas nos quartis inferiores. As variáveis morar com os dois pais e ter pais melhor escolarizados também geraram um efeito positivo no avanço educacional da criança.

Qualificar melhor os professores também é uma iniciativa que reduz a defasagem escolar, tendo em vista o sinal negativo de seu coeficiente. Além do mais, aumentar a proporção de escolas com laboratórios de informática e/ou concentrar os recursos do PDDE em iniciativas que melhorem as condições de ensino das escolas também diminui a probabilidade de a criança atrasar-se em seus estudos.

A exemplo de São Paulo, as variáveis média de alunos por turma e logaritmo da renda média do professor foram significativas, mas apresentaram um sinal diferente do esperado. Lembrando que a média de alunos por turma não foi significativa para as regressões da freqüência escolar, acredita-se que as duas variáveis estejam captando, novamente, os efeitos de variáveis não observadas na amostra.

Behrman et al. (1997) também fizeram um estudo para o Paquistão, no qual incluíram variáveis das características dos professores e da infra-estrutura escolar. Nesse estudo, o desempenho dos alunos na escola alcançaria uma melhoria significativa concentrando mais investimentos na qualificação do professor, do que na estrutura escolar física e de equipamentos.

Para as interações com a escolaridade do chefe de família e com o logaritmo da renda familiar per capita foram escolhidas a média de anos de estudo do professor e a proporção de escolas com laboratório de informática, as quais foram negativas e significativas na regressão 1 .

As interações da proporção de escolas com laboratório de informática, com a escolaridade do chefe de família e com o logaritmo da renda familiar per capita, podem ser vistas nas regressões 2 e 3, tendo sido significativas e positivas. Existe, portanto, 
uma relação de substitutibilidade entre as variáveis. Com isso, políticas que se preocupem em aumentar o número de escolas com laboratórios de informática, nos municípios pernambucanos, poderão beneficiar mais as crianças pertencentes a famílias em que os chefes não têm escolaridade, ou possuem baixos níveis de educação. Da mesma forma, também serão mais beneficiadas, as crianças moradoras em domicílios cuja renda familiar per capita é baixa.

Rios-Neto et al. (2002) usando dados da PNAD de 1998, para o Brasil encontraram resultados parecidos com os vistos nesse trabalho. Em suas interações, as variáveis da escolaridade média dos professores e da educação da mãe apareceram como bens substitutos na probabilidade de progressão por série. Entretanto, esses autores não cruzaram informações com o banco de dados do MEC, a fim de verificar outras características da infra-estrutura escolar, da forma como está sendo feita no presente trabalho.

Tabela 23. Efeitos marginais das regressões próbite para o atraso escolar no ensino fundamental, de escolas públicas, localizadas em área urbana, de Pernambuco

\begin{tabular}{lccc}
\hline \multicolumn{1}{c}{ Variáveis } & Regressão 01 & Regressão 02 & Regressão 03 \\
\hline Idade & $0,179^{*}$ & $0,179^{*}$ & $0,179^{*}$ \\
Idade ao quadrado & $-0,000889^{*}$ & $-0,000892^{*}$ & $-0,000889^{*}$ \\
Sexo (menino = 1) & $0,155^{*}$ & $0,155^{*}$ & $0,155^{*}$ \\
Cor ou raça (Branca foi omitida) & & & \\
Preta & $0,0912^{*}$ & $0,0910^{*}$ & $0,0909^{*}$ \\
Amarela & $-0,0503$ & $-0,0507$ & $-0,0502$ \\
Parda & $0,0418^{*}$ & $0,0416^{*}$ & $0,0417^{*}$ \\
Mesorregiões (Região metropolitana foi omitida) & & \\
Sertão Pernambucano & $0,0315^{*}$ & $0,0298^{*}$ & $0,0313^{*}$ \\
Agreste Pernambucano & $0,0389^{*}$ & $0,0375^{*}$ & $0,0392^{*}$ \\
Zona da Mata & $0,0149^{*}$ & $0,0135^{* *}$ & $0,0148^{* * *}$ \\
São Francisco & $-0,0157$ & $-0,0168$ & $-0,0152$ \\
Características da família & & & \\
Log. da renda familiar per capita & $-0,0414^{*}$ & $-0,0414^{*}$ & $-0,00296$ \\
Idade do chefe da família & $-0,000507^{*}$ & $-0,000515^{* *}$ & $-0,000505^{* *}$ \\
Escolaridade do chefe da família & $-0,0322^{*}$ & $-0,0457^{*}$ & $-0,0322^{*}$ \\
Sexo do chefe da família (homem $=1)$ & $-0,0475^{*}$ & $-0,0478^{*}$ & $-0,0475^{*}$ \\
& &
\end{tabular}


Tabela 23. Efeitos marginais das regressões próbite para o atraso escolar no ensino fundamental, de escolas públicas, localizadas em área urbana, de Pernambuco

\begin{tabular}{|c|c|c|c|}
\hline Variáveis & Regressão 01 & Regressão 02 & Regressão 03 \\
\hline \multicolumn{4}{|c|}{ Características da infra-estrutura escolar } \\
\hline Média de anos de estudo do professor & $-0,0183^{*}$ & $-0,0208 *$ & $-0,00636$ \\
\hline Log. da média salarial do professor & $0,0474 *$ & $0,0425 *$ & $0,0477 *$ \\
\hline $\begin{array}{l}\text { Proporção de escolas com laboratório } \\
\text { de informática }\end{array}$ & $-0,0597 * *$ & $-0,127 *$ & $-0,196 * *$ \\
\hline Média de alunos por turma & $-0,000496$ & $-0,000489$ & $-0,000489$ \\
\hline Repasses do PDDE (média) & $-0,00379 *$ & $-0,00372 *$ & $-0,00376^{*}$ \\
\hline \multicolumn{4}{|c|}{ Interações entre a infra-estrutura escolar e a escolaridade do chefe } \\
\hline $\begin{array}{l}\text { Méd. de anos de estudo do } \\
\text { professor } \times \text { Esc. do chefe da família }\end{array}$ & & 0,000992 & \\
\hline $\begin{array}{l}\text { Prop. escolas laboratório de } \\
\text { informática } \times \text { Esc. do chefe da família }\end{array}$ & & $0,0186 * *$ & \\
\hline \multicolumn{4}{|c|}{ Interações entre a infra-estrutura escolar e o log. da renda familiar per capita } \\
\hline $\begin{array}{l}\text { Méd. anos de estudo do profes. } \times \text { Log. } \\
\text { da renda familiar per capita }\end{array}$ & & & $-0,00336$ \\
\hline $\begin{array}{l}\text { Prop. escolas labor. de informática } \\
\times \text { Log. da renda familiar per capita }\end{array}$ & & & $0,0369 * * *$ \\
\hline Número de observações & 90.873 & 90.873 & 90.873 \\
\hline Teste Razão de Verossimilhança & $33.995,59 *$ & $34.000,97 *$ & 33.994,06* \\
\hline
\end{tabular}

Fonte: resultados da pesquisa

*denota significância ao nível de 1\%

**denota significância ao nível de 5\%

***denota significância ao nível de 10\%

Na Figura 10 podem ser visualizados os resultados da interação entre a proporção de escolas com laboratório de informática, tanto com a escolaridade do chefe de família, quanto com o logaritmo da renda familiar per capita, sobre o atraso escolar de Pernambuco, as quais são resultantes das equações abaixo.

$$
\begin{aligned}
& \Delta \text { Atraso }=-0,127+0,0186 \text { esc. chefe } \\
& \Delta \text { Atraso }=-0,196+0,0369 \text { log renda }
\end{aligned}
$$


Note que, quanto menos escolarizado é o chefe de família, maior é a queda no atraso escolar da criança pernambucana, em conseqüência de um aumento na proporção de escolas com laboratório de informática. Da mesma forma, em famílias com menor renda familiar per capita, os efeitos de uma melhoria na infra-estrutura escolar contribuem para a redução do atraso escolar.

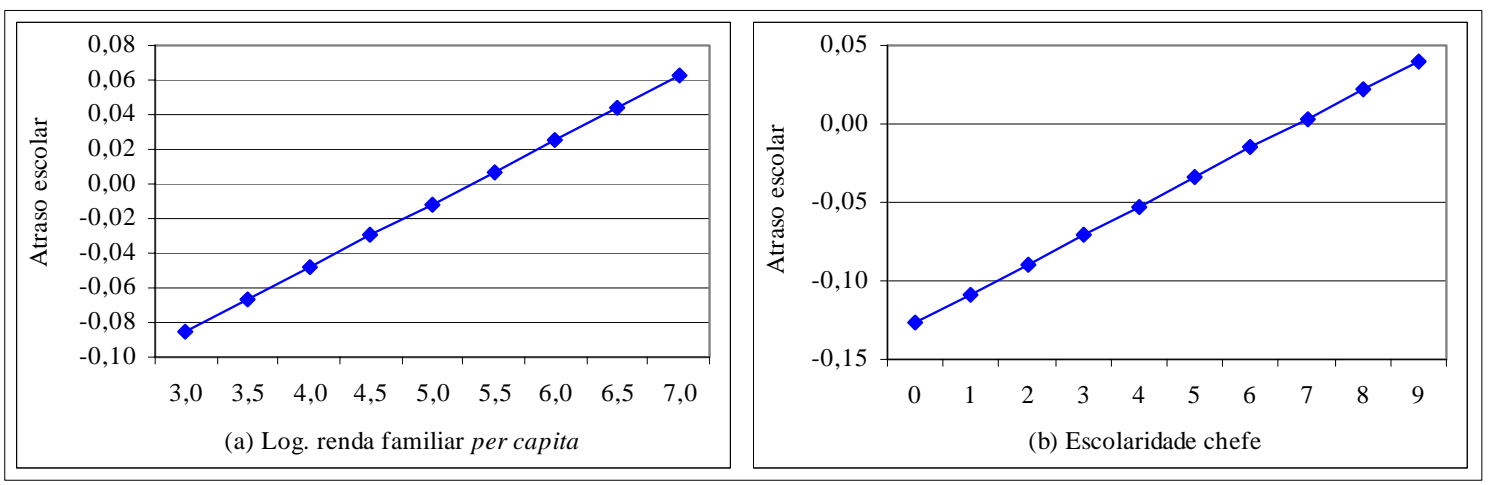

Figura 10 - (a) Efeito da interação entre o logaritmo da renda familiar per capita e a proporção de escolas com laboratório de informática, sobre o atraso escolar de Pernambuco (b) Efeito da interação entre a escolaridade do chefe de família e a proporção de escolas com laboratório de informática, sobre o atraso escolar de Pernambuco

Na Tabela 24 tem-se um resumo dos resultados obtidos nas interações entre as características familiares e a infra-estrutura escolar, que foram significativas até o nível de $10 \%$, nos dois estados analisados, para a freqüência e o atraso escolar.

Cabe destacar, que tanto em São Paulo, quanto em Pernambuco, as interações que incluíam variáveis associadas com as características do professor foram mais significativas, nas regressões da freqüência escolar. Por outro lado, nas regressões do atraso escolar, as interações mais significativas foram aquelas que cruzaram informações com variáveis mais diretamente ligadas com a infra-estrutura física da escola. 
No estado de São Paulo, melhorar a média de anos de estudo do professor é particularmente importante, para inserir e manter na escola as crianças que vivem em lares com chefes de família pouco escolarizados. Em Pernambuco, destaca-se a relação existente entre a remuneração média do professor e as características da família, visto que ocorreu efeito substituição nas regressões da freqüência escolar. Lembrando que a renda média desses profissionais é relativamente pequena em Pernambuco, quando comparado a São Paulo, oferecer-lhes melhores salários pode aumentar sua auto-estima, vindo a beneficiar as crianças pertencentes a famílias mais pobres. De outro modo, políticas voltadas para a educação de jovens e adultos, ou para o aumento da renda familiar per capita compensam a baixa remuneração dos professores e podem contribuir para aumentar o interesse da criança pela escola.

Tabela 24. Resultados das interações entre as características familiares e a infraestrutura escolar, sobre a freqüência e o atraso escolar - São Paulo e Pernambuco

\begin{tabular}{lcccc}
\hline \multicolumn{1}{c}{ Interações } & \multicolumn{2}{c}{ São Paulo } & \multicolumn{2}{c}{ Pernambuco } \\
& Freqüência & Atraso & Freqüência & Atraso \\
\hline $\begin{array}{l}\text { Média de anos de estudo do } \\
\text { professor } \times \text { Esc. do chefe da família }\end{array}$ & Substituto & & \\
$\begin{array}{l}\text { Log. méd. salarial do } \\
\text { professor } \times \text { Esc. do chefe da família }\end{array}$ & & & \\
$\begin{array}{l}\text { Log. méd. salarial do professor } \\
\times \text { Log. da renda familiar per capita }\end{array}$ & & Substituto & \\
$\begin{array}{l}\text { Prop. escolas labor. de informática } \\
\times \text { Esc. do chefe da família }\end{array}$ & Substituto & \\
$\begin{array}{l}\text { Prop. escolas labor. informática } \\
\times \text { Log. da renda familiar per capita }\end{array}$ & Substituto & & Substituto \\
\hline
\end{tabular}

Fonte: resultados da pesquisa

Nas interações do atraso escolar, em São Paulo e Pernambuco, observa-se o efeito substituição, em relação a proporção de escolas com laboratório de informática. 
Esses resultados são particularmente importantes para o momento atual vivido nos dois estados. A revisão de literatura mostrou que as políticas públicas atuais têm perseguido como meta principal a redução da defasagem escolar das crianças matriculadas no ensino fundamental. Dada a existência de um efeito substituição entre as variáveis, as iniciativas governamentais têm beneficiado mais as crianças pertencentes a famílias cujos chefes são pouco escolarizados e/ou a renda familiar per capita é baixa, o que poderá elevar os índices de desempenho escolar dos dois estados.

Os resultados aqui apresentados levam a refutar a hipótese inicial do trabalho, no tocante às características familiares das crianças, pois tanto em São Paulo, quanto em Pernambuco políticas que levem a melhoria da renda familiar per capita e/ou da escolaridade do chefe de família são de fundamental importância, para se elevar a freqüência e reduzir o atraso escolar das crianças. Lembrando que Pernambuco encontra-se em situação socioeconômica desfavorável, quando comparado a São Paulo, políticas adotadas para os dois estados devem privilegiar o estado de Pernambuco, na busca de resultados eficazes para estudantes do ensino fundamental.

\subsection{Simulações para orientar a seleção de políticas públicas}

As discussões sobre as políticas recentes do Ministério da Educação deixaram claro que a universalização do ensino fundamental e o combate da defasagem escolar nesse nível de ensino ainda são prioridades das políticas públicas voltadas para a educação. Em vista disso, a presente seção pretende analisar o impacto de intervenções nas variáveis associadas às características familiares e às características de infraestrutura escolar sobre as taxas de matrícula e de atraso escolar, tanto em São Paulo, quanto em Pernambuco. Para representar as características familiares será usada a escolaridade do chefe de família, em função das políticas voltadas para educação de jovens e adultos que têm sido adotadas no país. Outra variável a ser usada é o logaritmo da renda familiar per capita, dada a importância dos programas de transferência de renda existentes no Brasil a algum tempo. Para representar a infra-estrutura escolar 
foram escolhidas as variáveis que se apresentaram significativas e com um sinal de acordo com o esperado, nos modelos próbites descritos anteriormente.

A idade da criança é particularmente importante na probabilidade de estudar e de atrasar-se na escola, tendo em vista as variações observadas na Figura 1 e a significância estatística dessa variável nas regressões. Por isso, o efeito marginal das características familiares e das características relacionadas à infra-estrutura escolar foi calculado observando-se as mudanças na idade da criança. Utilizando-se os coeficientes do modelo próbite, observou-se a variação na probabilidade, em função da idade da criança. Para tanto, usou-se a média das variáveis explicativas, simulando alterações somente na média da variável explicativa de interesse. Ressalta-se, no entanto, que as estatísticas para o atraso escolar mostraram que as variações, em função da idade, são mais acentuadas no intervalo entre 9 e 16 anos, pois não há ocorrências de atraso escolar até os 9 anos e, acima dos 16 anos, todos os estudantes têm problemas de defasagem. Em vista disso, as simulações do atraso escolar serão apresentadas, considerando-se as variações ocorridas quando o aluno tem entre 9 e 16 anos.

A próxima seção apresenta os resultados das simulações na probabilidade de freqüência escolar mostrando-se, em seguida, as simulações referentes à probabilidade de atraso escolar.

\subsubsection{Simulações associadas à probabilidade de freqüência escolar}

A Figura 11 mostra as simulações realizadas para quatro variáveis explicativas, na freqüência escolar do estado de São Paulo. As variáveis escolhidas foram o logaritmo da renda familiar per capita, a escolaridade do chefe da família, a escolaridade do professor e a proporção de escolas com bibliotecas. Foram feitas variações a partir das médias dessas variáveis, mantendo-se as outras variáveis inalteradas e observando-se os deslocamentos na probabilidade estimada. 
Os resultados mostram que melhorias na renda familiar per capita são particularmente importantes para aumentar a probabilidade de freqüência escolar de São Paulo. Tomando-se os extremos de 8 e 13 anos como exemplo, essa probabilidade aumenta de 0,974 para 0,984 na idade de 8 anos e de 0,963 para 0,977 entre as crianças de 13 anos, quando se varia o sexo do chefe de família. Percebem-se, assim, aumentos de $1 \%$ e 1,4\% na taxa de freqüência à escola, respectivamente.
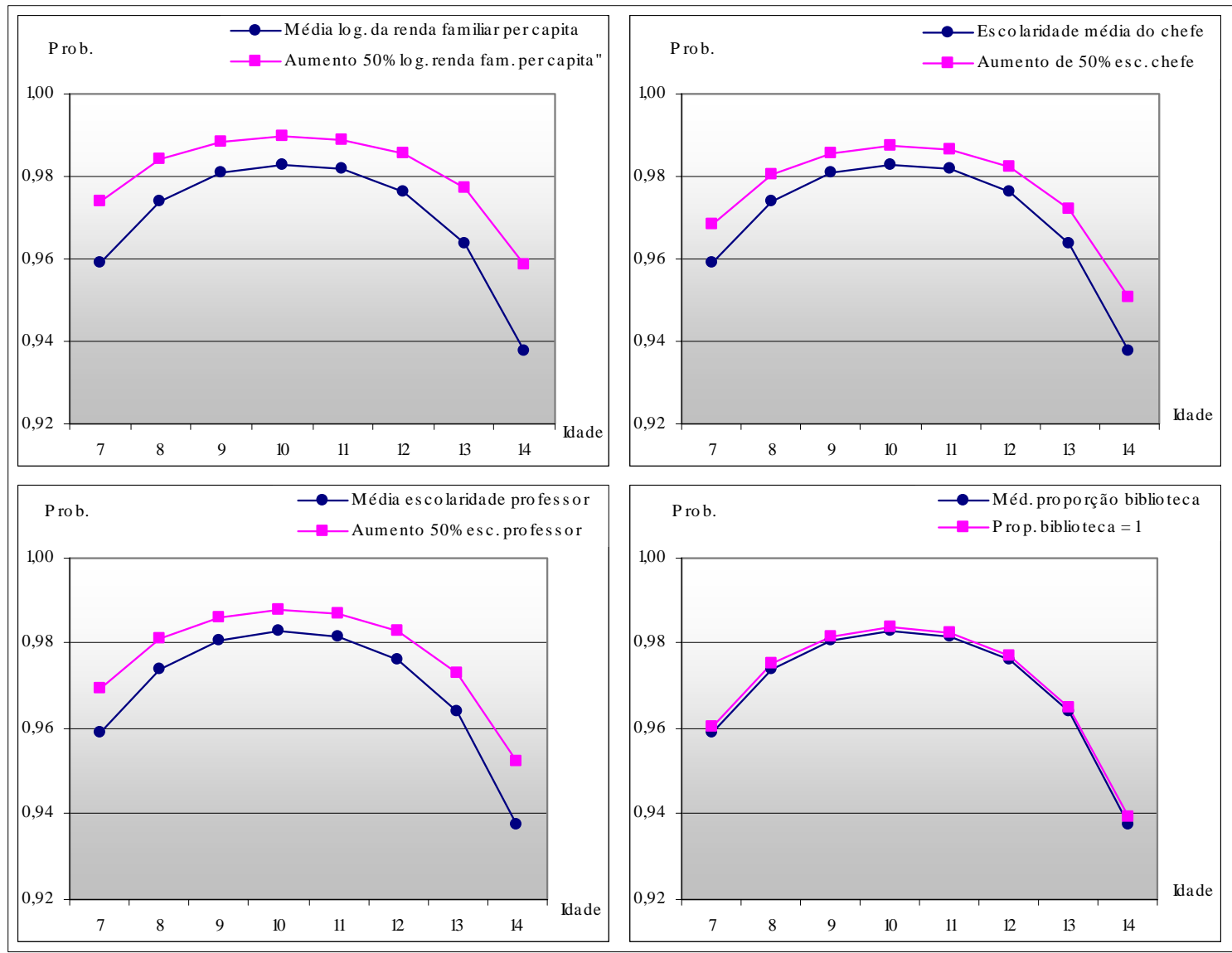

Figura 11 - Alterações na probabilidade de freqüência à escola da criança paulista, após mudanças em quatro variáveis explicativas

Em São Paulo, a escolaridade média do chefe de família corresponde a 5,99 anos de estudo e uma melhoria de 50\% eleva essa média para, aproximadamente, 9 anos de estudo. Uma política dessa natureza provocaria um aumento de 0,62\% na freqüência 
escolar das crianças de 8 anos e de 0,93\% na freqüência daquelas com 13 anos. A escolaridade média dos professores do ensino fundamental, de São Paulo, já é relativamente elevada e aumentá-la em 25\% seria similar a alcançar, em média, 16 anos de estudo para esses profissionais. Tal política elevaria em 0,72\% e 1,04\% a taxa de freqüência à escola das crianças de 8 e 13 anos, respectivamente. No ano 2000, em média 67\% das escolas paulistas tinham bibliotecas instaladas. Fazendo uma simulação para que todas as escolas tivessem bibliotecas, percebe-se que a probabilidade de freqüência escolar fica praticamente inalterada, em todas as faixas de idade observadas.

As simulações acima apresentadas para o estado de São Paulo mostraram que, dentre as possíveis políticas públicas que tenham o propósito de elevar a freqüência escolar das crianças, a iniciativa mais eficaz seria aumentar a renda familiar per capita das famílias onde essas crianças estão inseridas.

As mudanças na probabilidade de freqüência escolar da criança pernambucana podem ser vistas na Figura 12, tendo sido simuladas alterações no logaritmo da renda familiar per capita, na escolaridade do chefe da família, no logaritmo da renda mensal média do professor e na proporção de escolas com laboratório de informática.

No caso de Pernambuco, um aumento de 50\% no logaritmo da renda familiar per capita, provoca uma variação de 3,6 para 5,4. Em vista disso, a probabilidade de freqüência escolar da criança de 8 anos, aumenta de 0,924 para 0,94, o que corresponde a 1,73\%. Já entre as crianças de 13 anos, haveria uma melhoria de 1,96\% na taxa de freqüência escolar, a qual passaria de 0,917 para 0,935. Melhorar em 50\% a escolaridade média do chefe de família, representa aumentá-la de 3,88 para 5,82 anos de estudos. Com isso, aumenta-se em 1,62\% a probabilidade para as crianças de 8 anos e em 1,64\% a probabilidade para aqueles de 13 anos.

Para o logaritmo da renda média do professor também se simulou um aumento de 50\%, o qual passaria de 5,81 para 8,71. A Figura 8 mostra que essa simulação política tem forte influência sobre a probabilidade de freqüência escolar, 
tendo em vista o maior deslocamento da curva. Em conseqüência, as chances das crianças de 8 e 13 anos entrarem na escola aumentam em 4,33\% e 4,69\%, respectivamente. A proporção média de laboratórios de informática, em Pernambuco, é de 0,05 e a simulação aqui apresentada propôs que metade das escolas pernambucanas viesse a ter essa infra-estrutura. Nota-se, com isso, que as crianças de 8 anos terão um aumento em sua probabilidade de freqüência escolar da ordem de 2,81\%, enquanto a variação para as crianças de 13 anos corresponde a 3\%.

As simulações para a freqüência escolar mostraram que, em Pernambuco, melhorar a escolaridade do chefe de família e a renda familiar per capita é de fundamental importância para aumentar a probabilidade de freqüência entre as crianças de 7 a 14 anos. No entanto, melhorar a infra-estrutura da escola, no que se refere aos equipamentos disponíveis para a educação dos alunos, bem como ao salário dos professores, são políticas de maior influência na taxa de freqüência escolar.

As estatísticas anteriores evidenciaram que, em Pernambuco, o número de escolas com uma infra-estrutura adequada para suas crianças é bem inferior ao observado no estado de São Paulo. Talvez, por isso, investir na infra-estrutura seja uma política comparativamente mais viável naquele estado, dada a necessidade de reduzir a precariedade de suas escolas.

Quanto ao salário dos professores, os resultados das simulações confirmam as evidências já observadas por ocasião das interações, de que elevar a renda desses profissionais, para um nível mais próximo daquele recebido pelos professores de São Paulo, é um fator decisivo para a elevação da escolaridade em Pernambuco. 

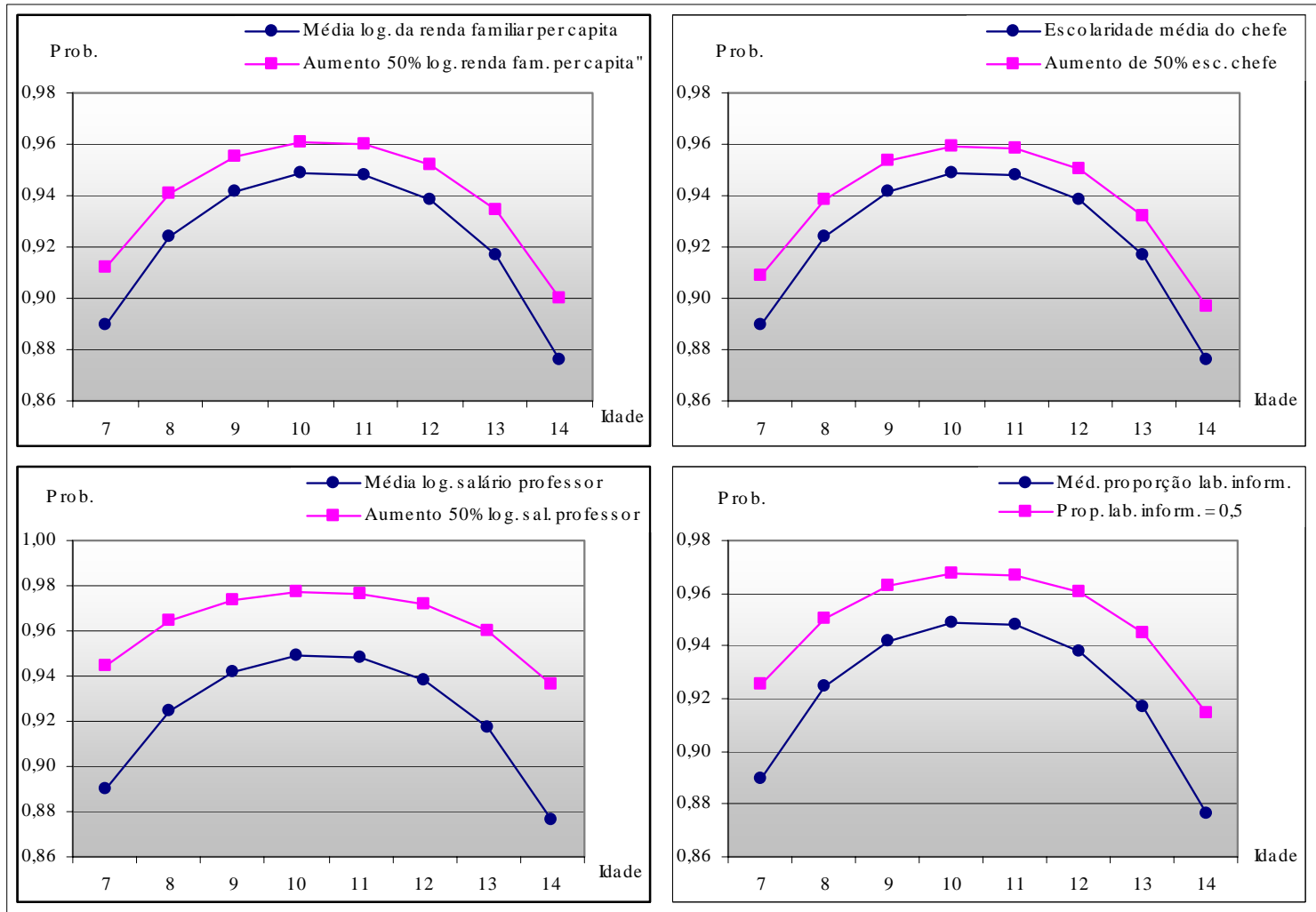

Figura 12 - Alterações na probabilidade de freqüência à escola da criança pernambucana, após mudanças em quatro variáveis explicativas

Comparando-se as simulações realizadas para a escolaridade do chefe de família e para a proporção de escolas com laboratórios de informática, ressalta-se que para obter os resultados acima, foi necessário simular uma alteração substancialmente grande na proporção média de laboratórios de informática, correspondente a uma quantidade 7,5 vezes maior do que existia disponível no estado em 2000. Já a escolaridade média do chefe de família aumentou em 1,5 vezes para obterem-se os resultados apresentados nas simulações. Conhecer os custos dos investimentos em cada uma dessas melhorias poderia contribuir para uma tomada de decisão sobre a melhor política a ser adotada. 


\subsubsection{Simulações associadas à probabilidade de atraso escolar}

As simulações da Figura 13 mostram os deslocamentos na curva que representa a probabilidade de atraso escolar da criança paulista, a partir de variações no logaritmo da renda familiar per capita, na escolaridade média do chefe de família, na escolaridade média do professor e na proporção média de escolas com laboratórios de informática. Seguindo o mesmo raciocínio utilizado para a freqüência escolar, a curva de atraso escolar é formada em função da idade da criança analisada, sendo positivamente inclinada no intervalo de 8 a 16 anos. Ou seja, quanto maior a idade da criança, maior a probabilidade de atraso escolar.

A influência das variáveis explicativas, sobre alterações na taxa de atraso escolar é mais perceptível nas idades mais elevadas, provavelmente, porque nessas idades a defasagem escolar seja maior. Percebe-se que até os 12 anos a probabilidade de atraso escolar é bastante reduzida, aumentando substancialmente entre 13 e 16 anos. Esse resultado pode estar sendo influenciado pelo regime de progressão continuada, que foi implantado no estado a partir de 1996. Em vista disso, as crianças mais velhas foram menos atingidas pelo programa, em comparação às crianças mais novas.

A renda familiar per capita mantém-se como uma variável relevante nas possíveis mudanças que uma criança pode ter em sua vida escolar. Utilizando como exemplo as idades de 14 e 16 anos, vê-se que a probabilidade de atraso escolar dos estudantes de 14 anos diminui de 0,333 para 0,252, quando a média do logaritmo da renda familiar per capita aumenta em 50\% (de 4,78 para 7,17). Tem-se, portanto, uma variação de 24,3\% nessa probabilidade. Entre as crianças de 16 anos a variação é de $8,9 \%$ e a taxa de defasagem escolar diminui de 0,804 para 0,732 . 
Aumentar em 50\% a escolaridade média do chefe de família provoca deslocamentos um pouco menos expressivos que no caso anterior. Nesse caso, a escolaridade média do chefe de família aumenta de 5,88 para 8,82 anos de estudo. Essa variação reduz o atraso escolar das crianças de 14 anos em 19,5\%, a qual diminui para 0,268. Entre os estudantes de 16 anos a redução percentual é bem menor (7\%), com uma queda na probabilidade de atraso escolar para 0,748.
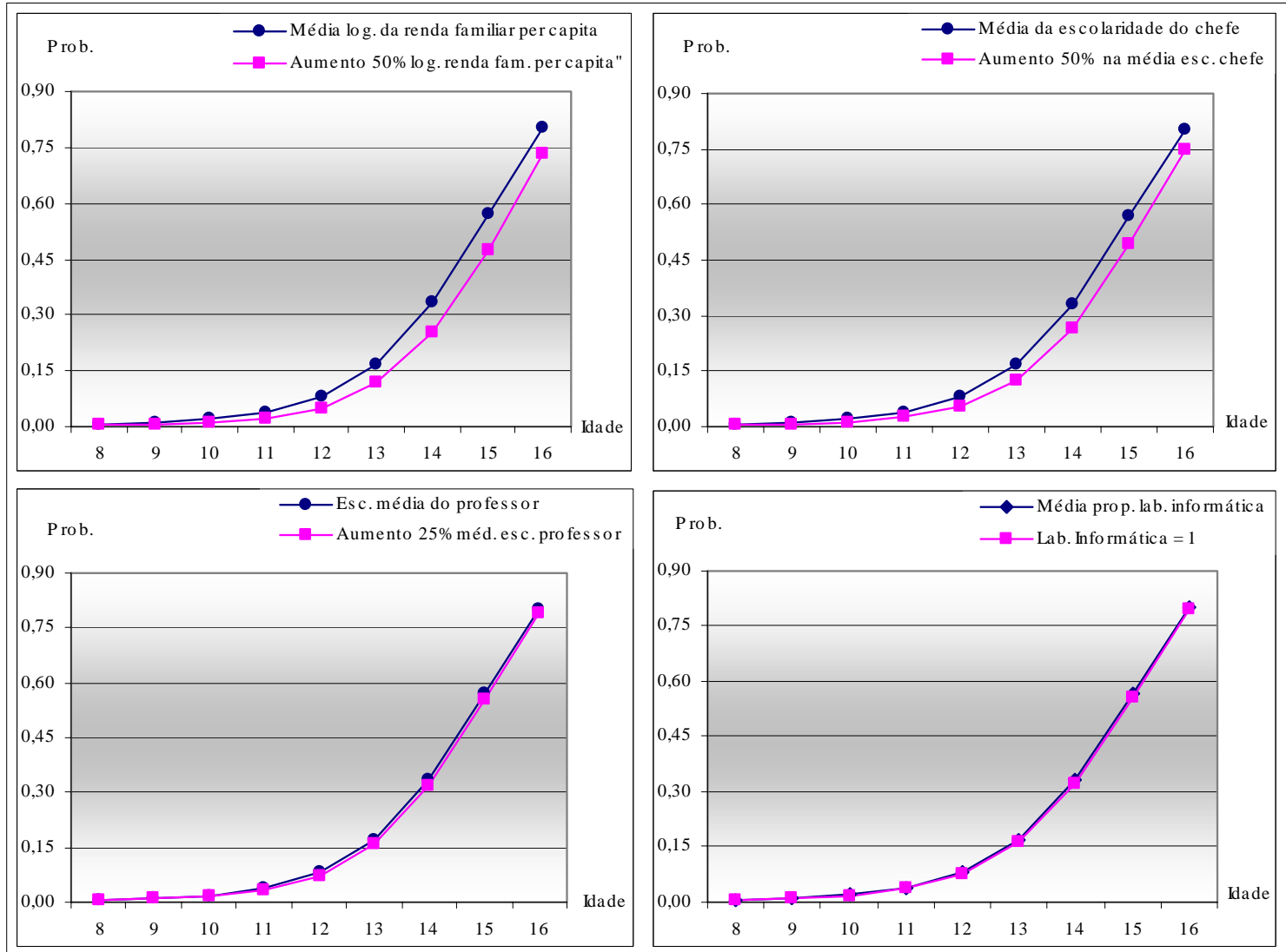

Figura 13 - Alterações na probabilidade de atraso escolar da criança paulista, após mudanças em quatro variáveis explicativas

Assim como foi feito para as simulações da freqüência escolar, o aumento de 25\% na escolaridade do professor faria essa variável atingir uma média aproximada de 16 anos de estudo, sendo um pouco maior que ensino superior completo. Percebe-se que tal variação tem pouca influência sobre a redução na probabilidade de atraso escolar. 
Entre as crianças de 14 anos essa redução seria de 4\%, enquanto a variação para os estudantes de 16 anos corresponde a 1,4\%. Simular uma situação em que todas as escolas do estado de São Paulo tenham laboratório de informática levou a perceber que essa variável tem influência ínfima sobre a redução do atraso escolar. Isso pode ser notado na quase inexistência de deslocamento na curva da Figura 13.

Os deslocamentos na curva de probabilidade de atraso escolar, para o estado de Pernambuco, são um pouco diferente dos percebidos para São Paulo (Figura 14). Nota-se que, se houver um aumento na média do logaritmo da renda familiar per capita, a taxa de atraso escolar diminui. No entanto, em Pernambuco, a variação percentual é inferior àquela vista para São Paulo. Entre as crianças de 14 anos, a redução na defasagem escolar é de 3,2\% (cai de 0,768 para 0,743). Para os estudantes de 16 anos a taxa de atraso escolar reduz-se de 0,933 para 0,922, o que representa uma queda de $1,2 \%$.

Melhorar a escolaridade média do chefe de família é uma política de maior impacto, quando se deseja reduzir os problemas de atraso escolar vividos pela criança pernambucana. Para o número de observações aqui analisadas simulou-se que essa variável passaria de 3,89 para 5,84 anos de estudo. Com isso, o atraso escolar das crianças com 14 anos seria alterado de para 0,718, o que corresponde a uma queda de 6,5\%. A redução percentual seria um pouco menos entre os estudantes de 16 anos (2,5\%), visto que a probabilidade de defasagem escolar diminuiria para 0,91.

Se a média de anos de estudo dos professores do ensino fundamental aumentasse em 25\% alcançar-se-ia o ensino superior completo. Essa mudança provocaria reduções de 5,9\% e 2,25\% na probabilidade de atraso escolar, das crianças de 14 e 16 anos, respectivamente. A exemplo do que foi visto no estado de São Paulo, aumentar os laboratórios de informática disponíveis na escola tem pouca influência sobre o desempenho escolar das crianças. Simulou-se, novamente, que metade das escolas pernambucanas tivessem laboratórios de informática. Também nesse caso, o deslocamento da curva é quase imperceptível. 

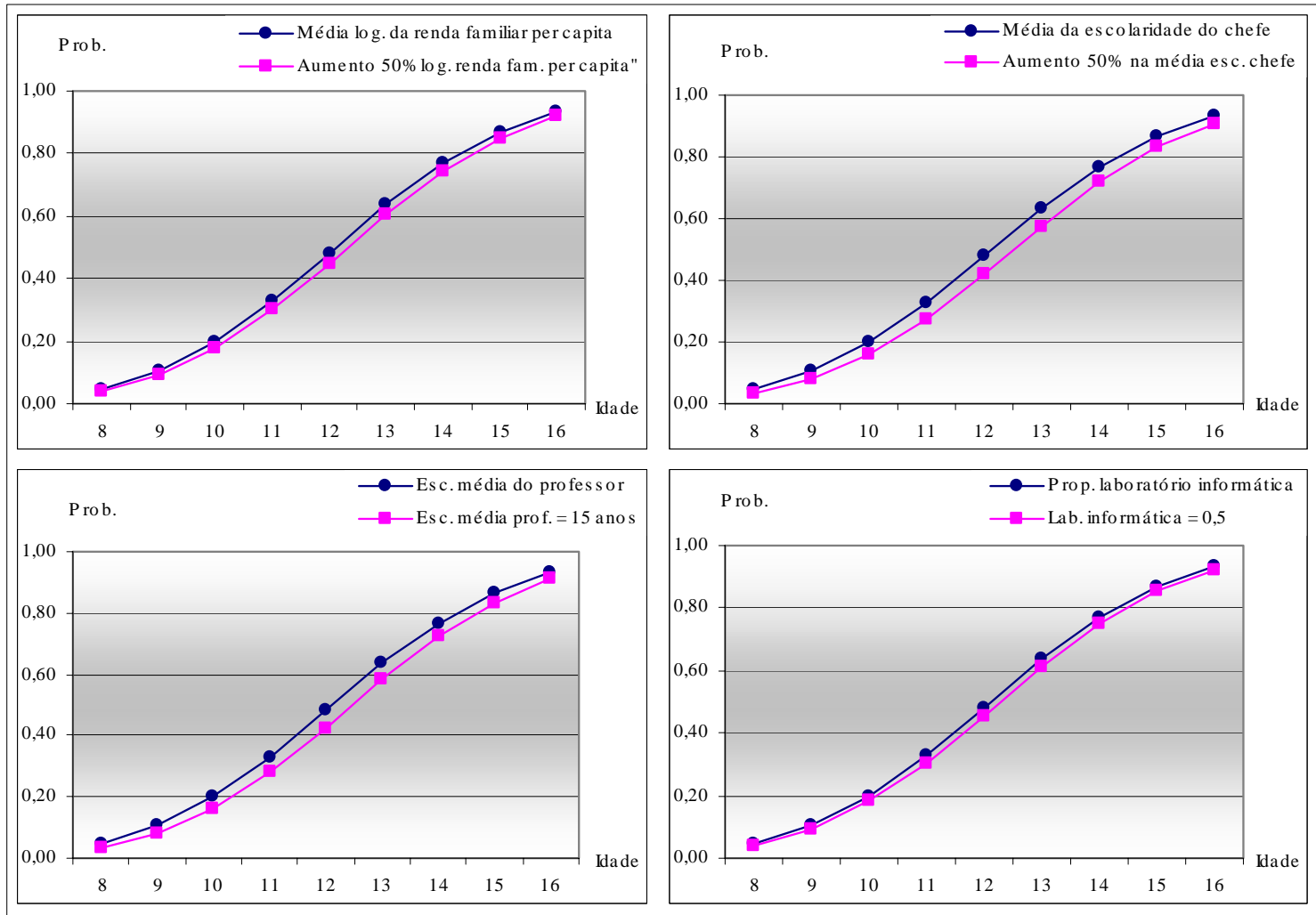

Figura 14 - Alterações na probabilidade de atraso escolar da criança pernambucana, após mudanças em quatro variáveis explicativas

A principal diferença entre as simulações realizadas nas probabilidades de freqüência e atraso escolar diz respeito aos resultados obtidos para a variável que representa a disponibilidade de bibliotecas e laboratórios de informática. Tanto em São Paulo, quanto em Pernambuco essa variável teve um efeito quase nulo sobre o desempenho escolar dos estudantes. No que se refere ao efeito sobre a freqüência escolar, em São Paulo ele também foi muito pequeno, mas em Pernambuco foi relativamente expressivo. Tanto que seu impacto provocou um deslocamento ligeiramente superior ao das variáveis representativas das características familiares, na curva que representa a probabilidade de freqüência escolar. 
Quanto às semelhanças, as variáveis associadas às características dos professores merecem destaque, pois somente na redução da probabilidade de atraso escolar, da criança paulista, seu efeito foi pequeno. Nos outros casos, melhorar a escolaridade do professor melhora substancialmente as condições de ensino das crianças do ensino fundamental. Na probabilidade de freqüência escolar, da criança pernambucana, um aumento de $50 \%$ na média salarial do professor surtiu um efeito maior que aquele observado para as outras três variáveis analisadas.

Em todas as simulações, melhorar em 50\% o logaritmo da renda familiar per capita surte um grande efeito sobre o indicador escolar analisado. Tanto que, somente no caso do atraso escolar de Pernambuco, melhorias na escolaridade do chefe de família provocam alterações superiores àquelas vistas para a renda familiar per capita. Handa (2001) encontrou resultados parecidos com esses últimos nas simulações realizadas para Moçambique. Nesse trabalho, alfabetizar melhor o chefe de família aumentava em até $15 \%$ a taxa de matrícula escolar, percentual esse, que era superior ao de todas as outras variáveis observadas. Leon \& Menezes-Filho (2002) realizaram simulações comparando as características familiares (escolaridade e renda do chefe de família), com a característica individual da criança (idade) na probabilidade de avanço escolar, após a conclusão das séries diplomas, no Brasil ( $4^{\mathrm{a}}$ e $8^{\mathrm{a}}$ séries e $3^{\mathrm{o}}$ ano do ensino médio), no período de 1984 a 1997. Os autores perceberam que as variáveis de origem familiar (educação e renda do chefe) ganham importância ao longo do ciclo escolar, especialmente quando se trata da inserção no ensino superior. Ressalta-se, no entanto, que esses autores não incluíram variáveis de infra-estrutura escolar em suas regressões.

O presente estudo indicou que, tanto investimentos visando melhorar as características familiares da criança, quanto investimentos que visam a melhoria da infra-estrutura escolar, surtirão efeitos sobre a vida escolar da criança. A decisão sobre a melhor política a ser adotada dependerá dos objetivos que se pretende alcançar, nos dois estados (pretende-se aumentar a freqüência ou reduzir o atraso escolar?). Tais decisões também dependem dos custos relativos de cada investimento. Sugere-se, portanto, a 
realização de pesquisas que levem em conta os custos associados às melhorias socioeconômicas aqui comentadas.

\subsection{Análise de situações extremas}

Antes de encerrar esse capítulo optou-se por fazer uma análise da situação educacional de uma criança inserida em famílias com as melhores condições socioeconômicas possíveis e comparando-se com aquelas crianças inseridas em famílias com condições socioeconômicas precárias. A Figura 15 mostra os resultados para os estados de São Paulo e Pernambuco. Para São Paulo, simulou-se uma condição socioeconômica favorável para uma criança branca e do sexo feminino, que residisse na mesorregião Metropolitana e cujo chefe de família fosse um homem. Tanto para o atraso, quanto para a freqüência escolar, identificaram-se as crianças inseridas nas famílias que representam os $10 \%$ mais ricos da população (nono decil da renda familiar per capita). Também se trabalhou com o nono decil da escolaridade do chefe de família, da renda mensal média do professor e assim por diante, para todas as variáveis contínuas. No extremo oposto, colocou-se as crianças negras, do sexo masculino, moradoras da mesorregião de Itapetininga, que tinham uma mulher responsável pela família. Para as variáveis contínuas, selecionou-se o primeiro quartil, a fim de analisar os 25\% mais pobres da população. Na análise de Pernambuco, adotou-se a mesma estratégia escolhida para São Paulo, sendo que as crianças inseridas em condições socioeconômicas favoráveis são moradoras da mesorregião Metropolitana e as crianças de condições precárias residem na mesorregião do Agreste Pernambucano. 

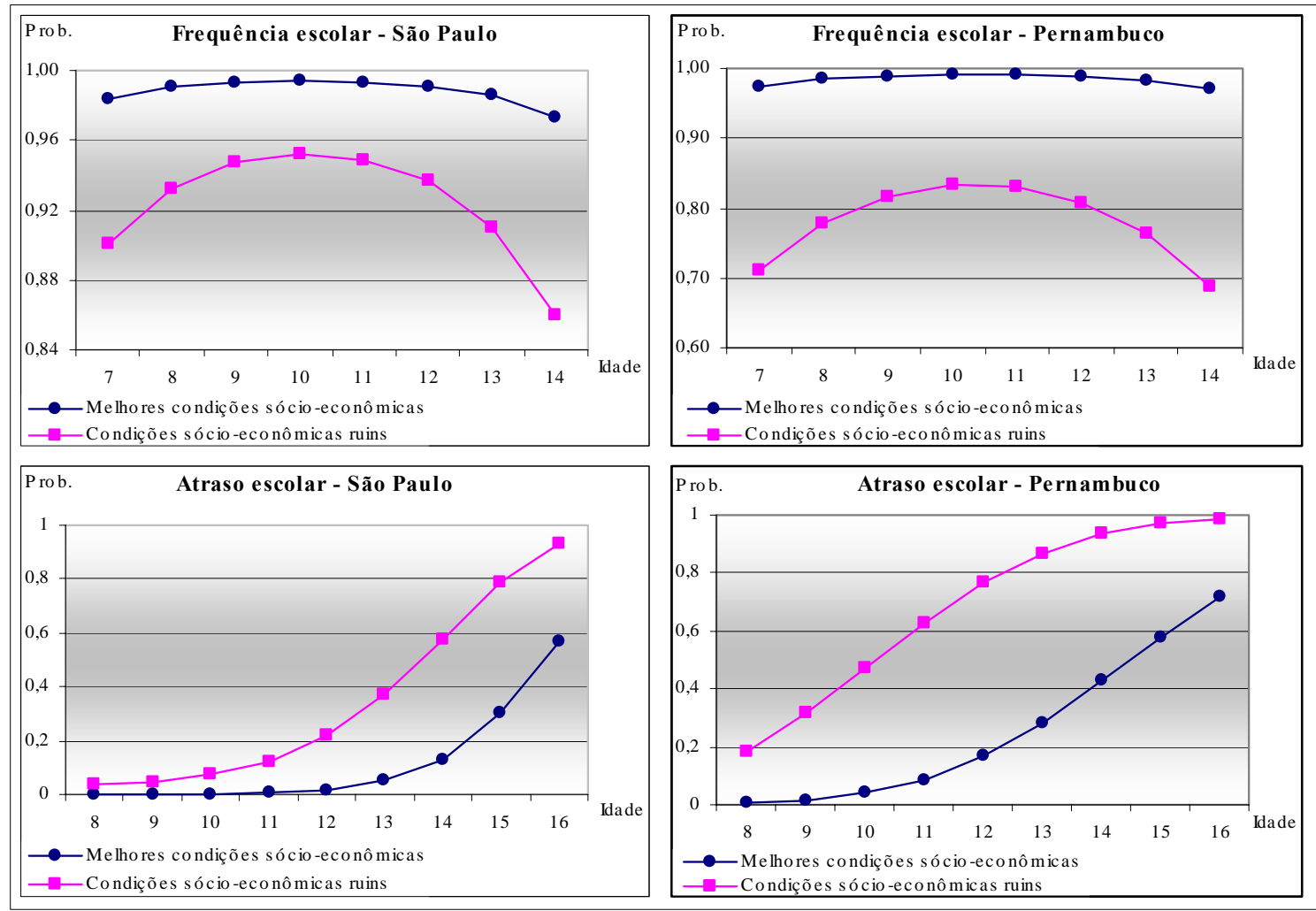

Figura 15 - Probabilidade de freqüência e atraso escolar, segundo condições socioeconômicas extremas

A Figura 15 mostra que, para a freqüência escolar, em Pernambuco, as diferenças entre as crianças inseridas nos dois extremos analisados são maiores que em São Paulo. Nesse caso, a freqüência escolar das crianças pernambucanas pertencentes a famílias com as melhores condições socioeconômicas chega a ser maior que em São Paulo, aproximando-se de 100\% em quase todos os intervalos de idades. Enquanto isso, as crianças pernambucanas de 14 anos, inseridas em famílias com condições socioeconômicas ruins a freqüência escolar é de 0,69, enquanto para as crianças paulistas essa freqüência é de 0,86. Entre as crianças pobres de 11 anos, as freqüências são de 0,83 e 0,95, para pernambucanos e paulistas, respectivamente. Comparando-se os dois extremos, a diferença na freqüência escolar entre as crianças pernambucanas de 8 anos é de 26,6\% e para as crianças de 13 anos é maior que 28\%. Já em São Paulo, as 
diferenças são de $6 \%$ e $8 \%$, para as crianças de 8 e 13 anos, respectivamente. Nos extremos de 7 e 14 anos essas diferenças aumentam, nos dois estados.

Ao analisar o atraso escolar, ao contrário da freqüência, a influência das diferenças socioeconômicas é mais forte em São Paulo. No entanto, a probabilidade de atraso escolar, da criança pernambucana, que pertence a famílias de condições socioeconômicas precárias, é maior que aquela observada para a criança paulista. Tanto que, a inclinação da curva de atraso escolar, em Pernambuco, é muito mais acentuada, quando a criança pertence a famílias de condições socioeconômicas ruins.

Adotando-se as idades de 11 e 15 anos para uma análise mais detalhada, nota-se que as crianças pernambucanas de 11 anos, pertencentes a famílias mais pobres, têm 63\% de chance, de atrasarem-se na escola, enquanto aquelas com uma condição socioeconômica mais favorável têm menos de $10 \%$ de chance, de ficarem defasadas em seus estudos. Entre aqueles de 15 anos, a diferença entre um extremo e outro é de 40,3\%. Para as crianças paulistas, o atraso escolar aproxima-se de zero, entre aquelas de 11 anos, inseridas em condições socioeconômicas favoráveis e é superior a 12\%, para as crianças do extremo oposto. Na idade de 15 anos, a diferença entre os dois extremos é de 61\% e as crianças pertencentes a uma condição socioeconômica ruim têm mais de 78\% de chance, de ficarem defasadas no ensino fundamental.

Tendo em vista as diferenças aqui observadas, políticas públicas que melhorem as condições socioeconômicas das crianças pobres poderão conduzir a uma redução das desigualdades existentes nos dois estados. 


\section{CONCLUSÕES}

"Referi-vos estas coisas para que tenhais a paz em mim. No mundo haveis de ter aflições. Coragem! Eu venci o mundo.”

(João 16:33.)

A proposta desse trabalho foi a de realizar uma avaliação dos impactos das características familiares e da infra-estrutura escolar, sobre a freqüência e o atraso no ensino fundamental, de escolas púbicas. Para tanto, optou-se em fazer uma análise comparativa dos estados de São Paulo e Pernambuco, tendo em vista as diferenças socioeconômicas existentes entre as regiões às quais os dois pertencem. Tal proposta constituiu-se no objetivo principal do trabalho, sendo que os objetivos secundários foram: i) investigar as interações entre fatores de oferta e demanda por escolaridade, a fim de fornecer subsídios quanto a melhor alocação dos recursos econômicos disponíveis; ii) realizar simulações para avaliar os impactos de um aumento na melhoria da qualidade das escolas, versus uma melhoria das condições socioeconômicas das famílias nos dois estados. Na busca dos resultados para os objetivos propostos estimouse o modelo próbite, para a área urbana dos dois estados, em que as variáveis dependentes foram a freqüência e o atraso escolar.

Nas estimativas do modelo próbite para a freqüência escolar, as variáveis que representam as características individuais e familiares da criança foram todas significativas e apresentaram o sinal esperado, nos dois estados. Os resultados indicaram 
a existência de diferenças raciais no acesso à educação, pois crianças negras e pardas têm menores chances de freqüentar a escola, do que crianças brancas. Além disso, nos dois estados, meninas estão mais propensas a ir para a escola que meninos e a probabilidade de freqüência escolar aumenta até os 10 anos, passando a reduzir-se entre 10 e 14 anos. Elevar a renda familiar per capita e a escolaridade do chefe de família afeta positivamente a freqüência escolar das crianças pernambucanas e paulistas. Ressalta-se, ainda, que a magnitude dos coeficientes associados às características familiares foi maior no estado de Pernambuco, quando comparado a São Paulo, indicando que essas variáveis exercem mais efeito sobre a procura por educação da criança pernambucana.

Dentre as variáveis de infra-estrutura escolar, em São Paulo, a média de anos de estudo do professor, a proporção de escolas com bibliotecas e a média de repasses do Programa Nacional de Alimentação Escolar (PNAE) foram significativas e apresentaram o sinal esperado. Em Pernambuco, as variáveis com essas características foram a média salarial do professor, a proporção de escolas com laboratório de informática e, novamente, a média de repasses do PNAE. Tais resultados indicam que investir na melhoria dessas variáveis pode elevar a freqüência escolar das crianças no ensino fundamental, dos estados analisados.

As interações foram realizadas para verificar a existência de efeito substituição ou complementaridade entre as características familiares e as características da infra-estrutura escolar. Em São Paulo, a interação entre a proporção de escolas com bibliotecas, com a renda familiar per capita mostrou que esses bens são substitutos, na probabilidade de freqüência escolar. Também agem como substitutos a escolaridade média do professor e a escolaridade do chefe de família. Em Pernambuco, as interações da variável salário do professor, com a escolaridade do chefe de família e a renda familiar per capita também apresentaram efeito substituição. Conclui-se, com isso, que no estado de São Paulo, aumentar a qualidade da escola com bibliotecas ou melhorar a escolaridade média do professor, poderá beneficiar mais as crianças de famílias com 
chefes pouco escolarizados e/ou com renda mais baixa. Em Pernambuco, as crianças de famílias mais pobres e/ou cujos chefes têm menor estudo também são mais beneficiadas com políticas voltadas para melhorar o salário do professor que leciona no ensino fundamental.

Ao realizar as estimativas tendo o atraso escolar como variável dependente, em ambos os estados, observou-se que meninos estão mais propensos a atrasar-se na escola, quando comparados às meninas. Além disso, crianças brancas têm menores chances de ficarem defasadas na escola, se comparadas a crianças pretas e pardas. Nos dois estados, as variáveis que representam as características familiares foram significativas, indicando que melhorias no ambiente familiar, no qual a criança está inserida, podem reduzir a probabilidade de defasagem escolar.

Das variáveis que representam as características da infra-estrutura escolar, os coeficientes da média de anos de estudo do professor e da proporção de escolas com laboratório de informática apresentaram-se significativos, reduzindo o atraso nos dois estados. Além disso, a média de repasses do Programa Dinheiro Direto na Escola (PDDE) mostrou-se importante em reduzir o atraso escolar, em Pernambuco. Em vista disso, à exceção do PDDE, essas variáveis foram escolhidas para realizarem-se as interações do atraso escolar.

Tanto em São Paulo, quanto em Pernambuco, somente a interação entre as características familiares e a proporção de escolas com laboratório de informática foi significativa. Os resultados levaram a concluir que aumentar o número de equipamentos disponíveis para o aprendizado da criança beneficia mais as crianças pertencentes a famílias pobres e/ou cujos responsáveis são pouco escolarizados. Por outro lado, dada uma infra-estrutura precária na escola, investir em políticas de transferência de renda, ou educação de jovens e adultos pode constituir-se numa iniciativa capaz de melhorar o desempenho escolar das crianças.

Nas simulações políticas foram comparados os impactos de melhorias na infra-estrutura escolar, versus melhorias nas variáveis de características familiares, sobre 
a freqüência e o atraso escolar das crianças pernambucanas e paulistas. Esses impactos foram observados a partir de deslocamentos nas curvas de freqüência e atraso escolar, tendo-se essas duas variáveis dependentes em função da idade da criança. O impacto de um aumento no logaritmo da renda familiar per capita foi expressivo, especialmente no caso da freqüência escolar, dos dois estados e no caso do atraso escolar, de São Paulo. Esse resultado indica que é possível obter retornos com os atuais programas de transferência de renda vigentes nos dois estados. Notou-se, ainda, que as diferenças nos indicadores educacionais de crianças pertencentes a uma condição socioeconômica favorável e crianças inseridas em situação socioeconômica mais precária são relativamente grandes. Em vista disso, os programas de transferência de renda devem favorecer famílias em condição de pobreza extrema, pois a renda recebida com o programa bolsa-escola, por exemplo, pode significar a diferença entre colocar a criança na escola ou inseri-la no mercado de trabalho.

No caso do atraso escolar de Pernambuco, aumentar a escolaridade do chefe de família causou maior impacto sobre a variável dependente, do que investir em melhorias da infra-estrutura escolar. Já nas simulações para a freqüência escolar, aumentar a média salarial do professor causou um impacto ligeiramente maior do que aumentar a escolaridade do chefe de família. Por essa razão, a decisão sobre a melhor política a ser adotada, depende do objetivo final a ser alcançado na área da educação.

Comparando-se os resultados das interações com as simulações políticas percebeu-se que, na maioria dos casos, melhorar as condições socioeconômicas das famílias das crianças é uma iniciativa que pode substituir a existência de professores mal-remunerados e desmotivados com seu trabalho, bem como de escolas com uma infra-estrutura precária. Nas simulações, aumentar a renda familiar per capita, ou a escolaridade do chefe de família mostrou-se como a política capaz de obter o melhor retorno, com relação aos indicadores educacionais dos dois estados. A única exceção, foi o caso da freqüência escolar de Pernambuco. Conclui-se, assim, que as iniciativas do poder público, preocupadas com a elevação da freqüência e a redução da defasagem escolar, nos estados analisados, devem preocupar-se em melhorar as condições 
socioeconômicas das famílias, uma vez que isso influencia positivamente as crianças com idade para estudar no ensino fundamental.

Entretanto, investimentos voltados para melhorar a situação sócioeconômica da família fornecem resultados eficientes somente no longo prazo. Por exemplo, para elevar em 50\% a escolaridade média do chefe de família é necessário implantar a educação de jovens e adultos. Como essas pessoas já trabalham e o custo de oportunidade de seu tempo é maior do que para uma criança, a motivação com os estudos pode diminuir ao longo do tempo, levando-os a desistir de participar do programa. Nesse caso, os esforços poderiam ser direcionados para inserir e manter as crianças na escola, a fim de que elas sejam adultos melhor escolarizados, capazes de ganhar uma melhor remuneração no mercado de trabalho e em condições de motivar seus próprios filhos a estudar. Mas, para que isso seja possível, a criança deve ter acesso a um ensino de qualidade, que lhe garanta a absorção de conhecimentos básicos. Sugerese, portanto, que as políticas públicas voltadas para a melhoria da infra-estrutura escolar sejam mais eficientes no curto-prazo e devam ser adotadas nos dois estados.

Para finalizar, destaca-se que os resultados anteriormente apresentados levaram a refutar a hipótese inicial do trabalho, no tocante às características familiares das crianças, pois tanto em São Paulo, quanto em Pernambuco podem ser adotadas políticas semelhantes de melhoria da renda familiar per capita e/ou da escolaridade do chefe de família. No entanto, foram evidenciadas algumas diferenças entre os dois estados. Por exemplo, a variável representativa do salário médio do professor mostrou-se um importante substituto da escolaridade do chefe de família e da renda familiar per capita, em Pernambuco. Em São Paulo, os melhores substitutos foram a escolaridade média do professor e a proporção de escolas com laboratório de informática. Além disso, as simulações políticas mostraram que melhorar o salário do professor é uma iniciativa mais eficaz, para o aumento da freqüência escolar, no estado de Pernambuco. Lembrando que Pernambuco encontra-se em situação socioeconômica desfavorável, quando comparado a São Paulo, políticas adotadas para os dois estados devem privilegiar o estado de Pernambuco. Especialmente porque a magnitude dos coeficientes 
associados às características familiares foi maior para o estado de Pernambuco, indicando maiores possibilidades de resultados eficazes num curto prazo. 


\section{REFERÊNCIAS BIBLIOGRÁFICAS}

ALBERNAZ, A.; FERRREIRA, F.G.H.; FRANCO, C. Qualidade e equidade no ensino fundamental brasileiro. Pesquisa e Planejamento Econômico, v.32, n.3, p.453476, dez. 2002.

BARROS, R.P. de; MENDONÇA, R. O impacto de três inovações institucionais na educação brasileira. Rio de Janeiro: IPEA, jun. 1998. 61p. (Texto para discussão, 566)

BARROS, R.P. de; MENDONÇA, R.; SANTOS, D. Uma análise do desempenho da educação média no Brasil. Rio de Janeiro: IPEA, abr. 1999. 83p.

BARROS, R.P. de; MENDONÇA, R.; SANTOS, D.D.; QUINTAES, G. Determinantes do desempenho educacional no Brasil. Rio de Janeiro: IPEA, out. 2001. 33p. (Texto para discussão, 834)

BARROS, R.P. de; RAMOS L. A note on the temporal evolution of the relationship between wages and education among brazilian prime-age males: 1976-1989. Rio de Janeiro: IPEA, 1992. 32p. (Texto para discussão, 279)

BECKER, G.S. A treatise on the family. Cambridge: Harvard University Press, 1991. $424 p$. 
BECKER, G.S. Human capital: a theoretical and empirical analysis with special reference to education. 3. ed. Chicago: The University of Chicago Press, 1993. 390p.

BECKER, G.S.; TOMES, N. An equilibrium theory of the distribution of income and intergenerational mobility. The Journal of Political Economy, v.87, n.6, p.11531189, Dec. 1979.

BEHRMAN, J.R.; KHAN, S.; ROSS, D.; SABOT, R. School quality and cognitive achievement production: a case study for rural Pakistan. Economics of Education Review, v.16, n.2, p.127-142, 1997.

BEHRMAN, J.R.; WOLFE, B.L. The socioeconomic impact of schooling in a developing country. The Review of Economics and Statistics, v.66, n.2, p.296303, May 1984.

BERTAGNA, R.H. Progressão continuada: limites e possibilidades. Campinas, 2003. 468p. Tese (Doutorado) - Faculdade de Educação, Universidade Estadual de Campinas.

BINDER, M. Community effects and desired schooling of parents and children in Mexico. Economics of Education Review, v.18, n.3, p.311-325, Jun. 1999.

BIRDSALL, N. Public inputs and child schooling in Brazil. Journal of Development Economics, v.18, n.1, p.67-86, Jun. 1985.

BLOM, A.; HOLM-NIELSEN, L.; VERNER, D. Education, earnings, and inequality in Brazil: 1982-1998: implications for education policy. Washington: The World Bank, 2002. http://www.lacea.org./meeting2001/Vener.pdf (25 Aug. 2003)

BRASIL. Congresso Nacional. Comissão Especial Mista. O desenvolvimento desigual da economia no espaço brasileiro. Brasília, 1993. v.1. p.32-68. (Relatório final) 
BRASIL. Leis, decretos, etc. Lei no 9.394 de 20 de dezembro de 1996. Diário Oficial, 23 dez. 1996. Seção 1, p.27839. Estabelece as diretrizes e bases da educação nacional. http://www.cidadania-e.com.br/legislacao.asp (03 abr. 2003)

BRASIL. Ministério da Educação e Desporto. Estudo sobre o valor mínimo do FUNDEF: relatório final/grupo de trabalho (port. $n^{\circ} 71$, de 27.01.2003 e $n^{\circ} 212$, de 14.02.2003). http://www.mec.gov.br/sef/fundef/default.shtm (10 jul. 2003)

BRASIL. Ministério da Educação e Desporto. Relatório síntese de divulgação dos resultados: $\quad$ Saeb $2001 . \quad$ Brasília, 2002. http://www.inep.gov.br/basica/saeb/default.asp (05 abr. 2003)

BRASIL. Ministério da Educação e Desporto. Fundo Nacional de Desenvolvimento da Educação. Relatório de atividades 1999. Brasília, 2000. http://www.fnde.gov.br/instituicao/mapa.html (15 maio 2003)

BRASIL. Ministério da Educação e Desporto. Fundo Nacional de Desenvolvimento da Educação. Relatório de atividades 2000. Brasília, 2001. http://www.fnde.gov.br/instituicao/mapa.html (15 maio 2003)

BRASIL. Ministério da Educação e Desporto. Fundo Nacional de Desenvolvimento da Educação. Relatório de atividades 2002. Brasília, 2003. http://www.fnde.gov.br/instituicao/mapa.html (15 maio 2003)

BRASIL. Ministério da Educação e Desporto. Grupo Permanente de Trabalho de Educação do Campo. Referências para uma política nacional de educação do campo: caderno de subsídios. Brasília, out. 2003. 40p. http://www.inep.gov.br/pesquisa/publicacoes/default.asp (15 set. 2004)

BRASIL. Ministério da Educação e Desporto. Instituto Nacional de Estudos e Pesquisas. Dicionários de indicadores educacionais: fórmulas de cálculo. Brasília, fev. 2004. http://www.inep.gov.br/pesquisa/publicacoes/default.asp (20 set. 2004) 
BRASIL. Ministério da Educação e Desporto. Instituto Nacional de Estudos e Pesquisas. Sinopses estatísticas da educação básica: Brasil, regiões e Unidades da Federação, 1999-2003. http://www.inep.gov.br/estatisticas/numeros/2001 (15 abr. 2004)

CARD, D.; KRUEGER, A.B. Does school quality matter ? Returns to education and the characteristics of public schools in the United States. Journal of Political Economy, v.100, n.1, p.1-40, Feb. 1992.

CASE, A.; DEATON, A. School inputs and educational outcomes in South Africa. The Quarterly Journal of Economics, v.114, n.458, p.1047-1084, Aug. 1999.

CASTRO, J.A. de; BARRETO, A.R.; CORBUCCI, P.R. A reestruturação das políticas federais para o ensino fundamental: descentralização e novos mecanismos de gestão. Rio de Janeiro: IPEA, 2000. 26p. (Texto para discussão, 745)

CASTRO, J.A. de; MENEZES, R.M. Avanços e limites na gestão da política federal de ensino fundamental nos anos 1990. Brasília: IPEA, 2003. 36p. (Texto para discussão, 947)

CASTRO, M.H.G. de. As desigualdades regionais no sistema educacional brasileiro. In: HENRIQUES, R. (Org.). Desigualdade e pobreza no Brasil. Rio de Janeiro: IPEA, 2000. cap.15, p.425-458.

CORRÊA, A.M.C.J.; HOFFMANN, R. Desigualdade de rendimentos na agricultura brasileira: uma análise regional. Pesquisa e Planejamento Econômico, v.27, n.2, p.279-312, ago. 1997.

DUFLO, E. Schooling and labor market consequences of school construction in Indonesia: evidence from an unusual policy experiment. The American Economic Review, v.91, n.4, p.795-812, 2001. 
FERRÃO, M.E.; BELTRÃO, K.I.; SANTOS, D.P. O impacto de políticas de nãorepetência sobre o aprendizado dos alunos da $4^{\text {a }}$ série. Pesquisa e Planejamento Econômico, v.32, n.3, p.495-513, dez. 2002.

GREENE, W.H. Econometric analysis. New York: Macmillan Publishing Company, 2003. 791p.

HANDA, S. The determinants of teenage schooling in Jamaica: rich vs. poor: females vs. males. The Journal of Development Studies, v.32, n.4, p.554-580, Apr. 1996.

HANDA, S. Raising primary school enrolment in developing countries: the relative importance of supply and demand. Journal of Development Economics, v.69, n.1, p.103-128, Oct. 2002.

HANUSHEK, E. The characteristics and gains in student achievement: estimation using micro data. The American Economic Review, v.61, n.2, p.280-288, 1971.

HOFFMANN, R. Desigualdade entre estados na distribuição de renda no Brasil. Economia Aplicada, v.1, n.8, p.281-296, abr./jun. 1997.

HOLMES, J. Measuring the determinants of school completion in Pakistan: analysis of censoring and selection bias. New Haven: Yale University, Jan. 1999. 42p. (Center discussion paper, 794)

INSTITUTO BRASILEIRO DE GEOGRAFIA E ESTATÍSTICA. Censo demográfico 2000: microdados: São Paulo (compact disc). Rio de Janeiro, 2000.

INSTITUTO BRASILEIRO DE GEOGRAFIA E ESTATÍSTICA. Censo demográfico 2000: microdados: Pernambuco (compact disc). Rio de Janeiro, 2000.

INSTITUTO BRASILEIRO DE GEOGRAFIA E ESTATÍSTICA. Pesquisa nacional por amostra de domicílios 1999: microdados (compact disc). Rio de Janeiro, 1999. 
INSTITUTO BRASILEIRO DE GEOGRAFIA E ESTATÍSTICA. Pesquisa nacional por amostra de domicílios 2001: microdados (compact disc). Rio de Janeiro, 2001.

INSTITUTO DE PESQUISA ECONÔMICA APLICADA. Novo atlas do desenvolvimento no Brasil. http://www.ipea.gov.br (18 ago. 2003)

KASSOUF, A.L. Demanda de saúde infantil no Brasil por região e setor. Pesquisa e Planejamento Econômico, v.24, n.2, p.235-260, ago. 1994.

KASSOUF, A.L. Returns to education and training program in the brazilian urban and rural sectors. Revista de Economia e Sociologia Rural, v.35, n.2, p.60-76, abr.jun. 1997.

KASSOUF, A.L. Accounting for education, experience and health as investments in human capital. In: GUILHOTO, J.J.M.; HEWINGS, G.J.D. (Org.). Structure and structural change in the brazilian economy: the political economy of Latin America. Burlington: Ashgate Publishing Limited, 2001. p.219-246.

KASSOUF, A.L.; SENAUER, B. Direct and indirect effects of parental education on malnutrition among children in Brazil: a full income approach. Economic Development and Cultural Change, v.44, n.4, p.817-838, July 1996.

LEON, F.L.L. de; MENEZES-FILHO. Reprovação, avanço e evasão escolar no Brasil. Pesquisa e Planejamento Econômico, v.32, n.3, p.417-451, dez. 2002.

MACHADO, A.F. Trabalhador por conta própria: heterogeneidade e desigualdade de renda em regiões metropolitanas. Viçosa, 1993. 235p. Dissertação (M.S.) Faculdade de Ciências Econômicas, Universidade Federal de Viçosa.

MAROPE, P.T.M. The impact of educational policy reforms on the distribution of educational outcomes in developing countries: The case of Botswana. Journal Educational Development, v.16, n.2, p.157-175, 1996. 
MINCER, J. Schooling, experience, and earnings. New York: National Bureau of Economic Research, 1974. 152p.

MONTEIRO, C.A. A dimensão da pobreza, da fome e da desnutrição no Brasil. Estudos Avançados, v.9, n.24, p.195-207, maio/ago. 1995.

NEUBAUER, R. Classes de aceleração: mais de 100 mil alunos da rede estadual paulista recuperam o atraso escolar. In: BRASIL. Ministério da Educação e Desporto. Instituto Nacional de Estudos e Pesquisas. Em aberto: programa de correção do fluxo escolar. Brasília, jan. 2000. v.17, n.71. p.41-48.

NEGRI, B. O fundo de manutenção e desenvolvimento do ensino fundamental e de valorização do magistério. Brasília: MEC/INEP, 1997. n.3. http://www.inep.gov.br/pesquisa/publicacoes/default.asp (10 jul. 2003)

NEVES, E.R.C.; BORUCHOVITCH, E. A motivação de alunos no contexto da progressão continuada. Psicologia: teoria e pesquisa, v.21, n.1, p.77-85, jan./abr. 2004.

PARENTE, M.M. de A.; LUCK, H. Mecanismos e experiências de correção do fluxo escolar no ensino fundamental. Brasília: IPEA, 2004. 38p. (Texto para discussão, 1032)

PEREIRA, D.J. de S. Diferenças de escolaridade e rendimento do trabalho nas regiões nordeste e sudeste do Brasil. Piracicaba, 2001. 98p. Dissertação (M.S.) - Escola Superior de Agricultura “Luiz de Queiroz”, Universidade de São Paulo.

PERNAMBUCO. Agência de Desenvolvimento Econômico de Pernambuco. Perfil socio-econômico do Estado. http://www.pernambuco.gov.br/principal2.htm (15 ago. 2003) 
PERNAMBUCO. Secretaria de Educação e Cultura. Lei $\mathrm{n}^{0} 12.252$ de 8 de julho de 2002. Diário Oficial do Estado, 03 ago. 2002. Seção 2, p.5-8. Aprova o Plano Estadual de Educação e dá outras providências. http://www.educacao.pe.gov.br/arquivos/pee.doc (07 set. 2004)

PERNAMBUCO. Secretaria de Educação e Cultura. Programas "se liga Pernambuco", “acelera Pernambuco" e "alfabetizar com sucesso". http://portalseduc2.interjornal.com.br/programas.kmf (07 set. 2004)

PROGRAMA DAS NAÇÕES UNIDAS PARA O DESENVOLVIMENTO (PNUD). Relatório de desenvolvimento humano 2002. http://www.pnud.org.br/rdh/ (15 set. 2003)

PRADO, I.G. de A. LDB e políticas de correção do fluxo escolar. In: BRASIL. Ministério da Educação e Desporto. Instituto Nacional de Estudos e Pesquisas. Em aberto: programa de correção do fluxo escolar. Brasília, jan. 2000. v.17, n.71. p.4956.

QUAGLIATO, M.F.T. Os estudos de recuperação no ensino fundamental: aprendizagem ou discriminação ? Campinas, 2003. 148p. Dissertação (M.S.) - Faculdade de Educação, Universidade Estadual de Campinas.

ROCHA, S. Pobreza no Brasil: o que há de novo no limiar do século XXI ?. Economia, v.2, n.1, p.73-106, jan./jun. 2001

RIOS-NETO, E.L.G.; CÉSAR, C.C.; RIANI, J. de L.R. Estratificação educacional e progressão escolar por série no Brasil. Pesquisa e Planejamento Econômico, v.32, n.3, p.395-415, dez. 2002.

SÃO PAULO. Conselho Estadual de Educação. Deliberação CEE n ${ }^{\circ}$ 09/97 de 30 de julho de 1997. Diário Oficial do Estado, 05 ago. 1997. p.12-13. Institui, no sistema de ensino de São Paulo, o regime de progressão continuada no ensino fundamental. http://www.ceesp.sp.gov.br/d09i8-97.html (07 set. 2004) 
SÃO PAUlO. Fundação Sistema Estadual de Análise de Dados. São Paulo 2000. http://www.seade.gov.br (15 ago. 2003)

SCHULTZ, T.W. O capital humano: investimentos em educação e pesquisa. Trad. de M.A. de M. Matos. Rio de Janeiro: Zahar, 1973. 250p.

SUMMERS, A.A.; WOLFE, B. Do schools make a difference ? The American Economic Review, v.67, n.4, p.639-652, Sep. 1977.

TANSEL, A. Determinants of school attainment of boys and girls in Turkey: individual, household and community factors. Ankara: Middle East Technical University, Feb. 2000. 21p.

UEDA, E.M.; HOFFMANN, R. Estimando o retorno da educação no Brasil. Brazilian Journal of Applied Economics, v.6, n.2, p.209-238, abr./jun. 2002.

VANCOSCELLOS, L.M. Frequiência e atraso escolar e sua relação com a renda familiar no Brasil. São Paulo, 2003. 128p. Tese (Doutorado) - Faculdade de Economia, Administração e Contabilidade, Universidade de São Paulo.

WOOD, C.H.; CARVALHO, J.A.M. A demografia da desigualdade no Brasil. Rio de Janeiro: IPEA, 1994. cap.3, p.61-99: Crescimento e distribuição: uma perspectiva histórica. 